Prepared in cooperation with the University of Wisconsin-Madison Discovery Farms program, the University of Wisconsin-Platteville Pioneer Farm program, the Wisconsin Department of Natural Resources, and the Sand County Foundation

\title{
Precipitation-Runoff Relations and Water-Quality Characteristics at Edge-of-Field Stations, Discovery Farms and Pioneer Farm, Wisconsin, 2003-08
}

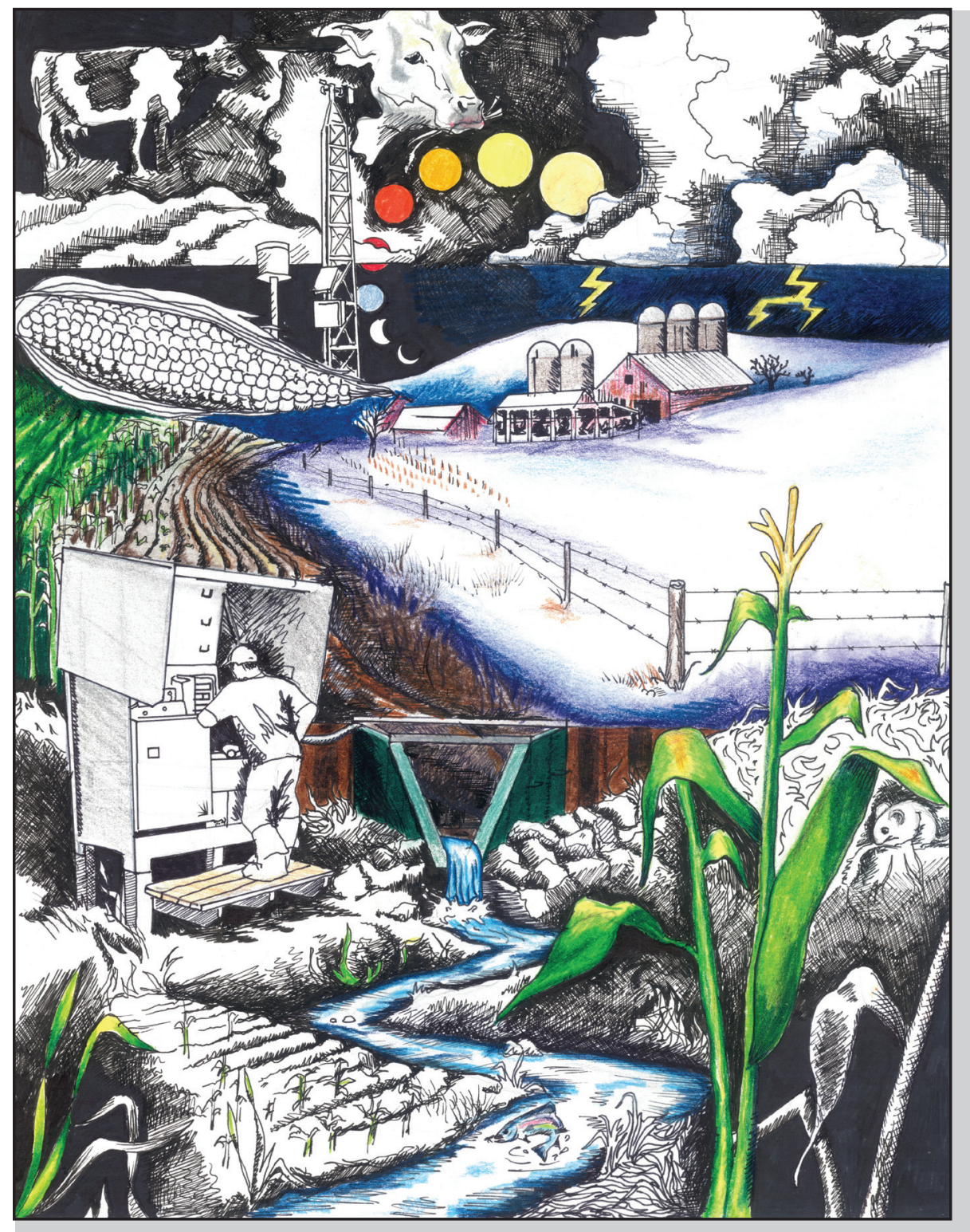

Scientific Investigations Report 2011-5008

U.S. Department of the Interior

U.S. Geological Survey 
Cover art: Drawing by Benjamin J. Siebers, U.S. Geological Survey, February 2011. 


\section{Precipitation-Runoff Relations and Water- Quality Characteristics at Edge-of-Field Stations, Discovery Farms and Pioneer Farm, Wisconsin, 2003-8}

By Todd D. Stuntebeck, Matthew J. Komiskey, Marie C. Peppler, David W. Owens, and Dennis R. Frame

Prepared in cooperation with the University of Wisconsin-Madison Discovery

Farms program, the University of Wisconsin-Platteville Pioneer Farm program, the Wisconsin Department of Natural Resources, and the Sand County Foundation

Scientific Investigations Report 2011-5008 


\title{
U.S. Department of the Interior \\ KEN SALAZAR, Secretary \\ U.S. Geological Survey \\ Marcia K. McNutt, Director
}

\section{U.S. Geological Survey, Reston, Virginia: 2011}

\author{
For more information on the USGS - the Federal source for science about the Earth, its natural and living resources, \\ natural hazards, and the environment, visit http://www.usgs.gov or call 1-888-ASK-USGS \\ For an overview of USGS information products, including maps, imagery, and publications, \\ visit http://www.usgs.gov/pubprod \\ To order this and other USGS information products, visit http://store.usgs.gov
}

\begin{abstract}
Any use of trade, product, or firm names is for descriptive purposes only and does not imply endorsement by the U.S. Government.

Although this report is in the public domain, permission must be secured from the individual copyright owners to reproduce any copyrighted materials contained within this report.
\end{abstract}

Suggested citation:

Stuntebeck, T.D., Komiskey, M.J., Peppler, M.C., Owens, D.W., and Frame, D.R., 2011, Precipitation-runoff relations and water-quality characteristics at edge-of-field stations, Discovery Farms and Pioneer Farm, Wisconsin, 2003-8: U.S. Geological Survey Scientific Investigations Report 2011-5008, 46 p. 


\section{Acknowledgments}

The authors thank Kevan Klingberg, Eric Cooley, Nancy Drummy, and Aaron Wunderlin from Discovery Farms and Randy Mentz from Pioneer Farm for their assistance with preparing the farm-description sections. Field support was provided by Tim Radatz, Amber Radatz, Susan Frame, and Tim Popple from Discovery Farms and Justin Daugherty from Pioneer Farm. Administrative and technical support was provided by Judy Goplin and Fred Madison from Discovery Farms and Thomas Hunt and Dennis Busch from Pioneer Farm. Laboratory analysis was provided by Dick Stephens, with assistance from Eric Frank and Chris Merkes from University of Wisconsin-Stevens Point Water and Environmental Analysis Laboratory. Special thanks are also extended to the farm families that participated in this study for their generous offerings of time and equipment. 


\section{Contents}

Acknowledgments ......................................................................................................................ii

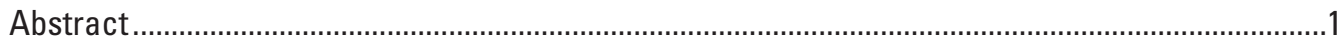

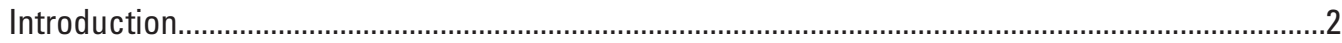

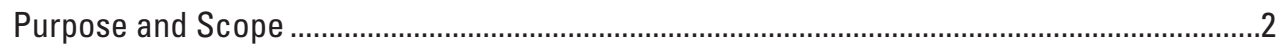

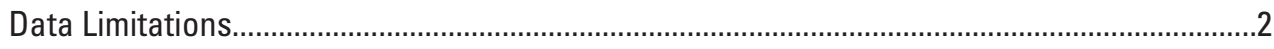

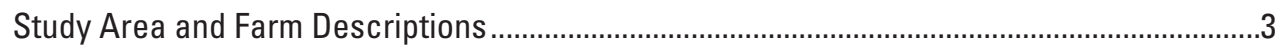

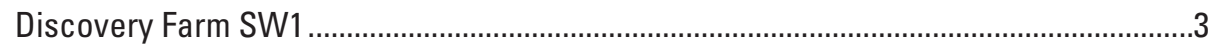

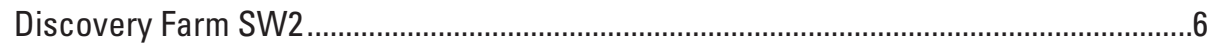

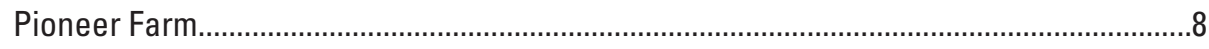

Discovery Farm SE1 .......................................................................................................12

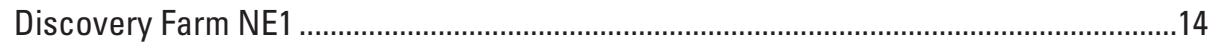

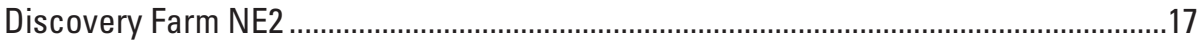

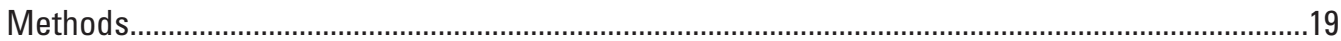

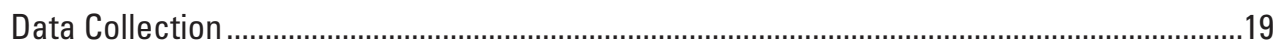

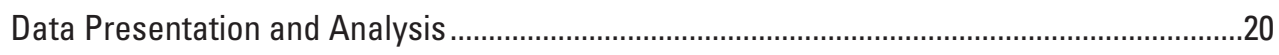

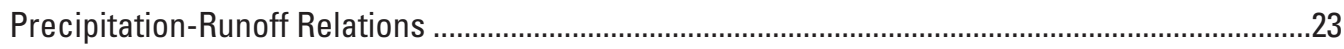

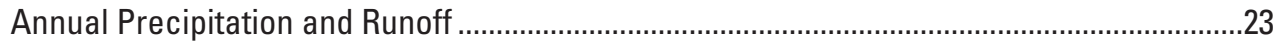

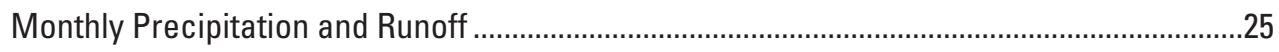

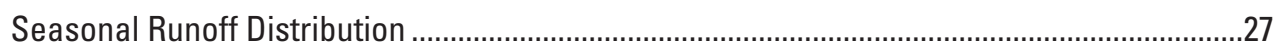

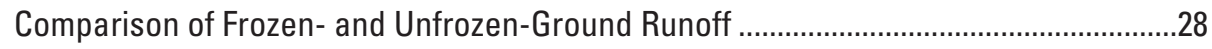

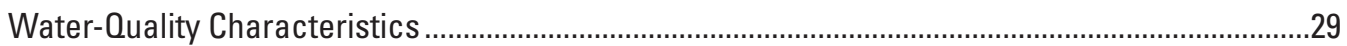

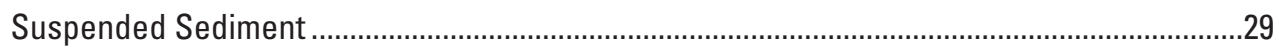

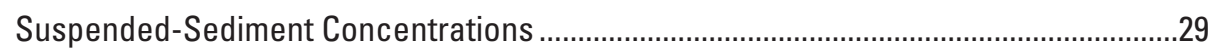

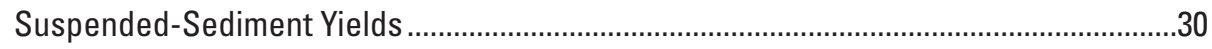

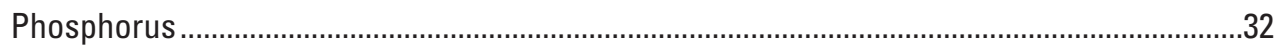

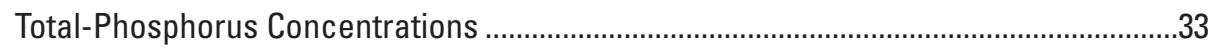

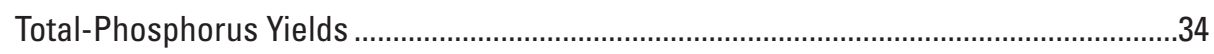

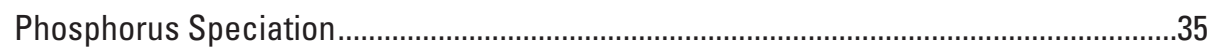

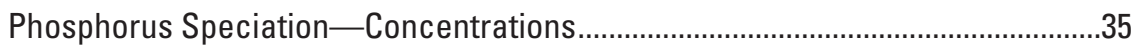

Phosphorus Speciation —Yields..........................................................................

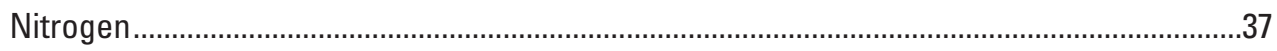

Total-Nitrogen Concentrations ..............................................................................37

Total-Nitrogen Yields ...........................................................................................

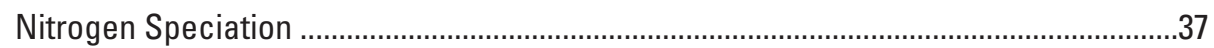

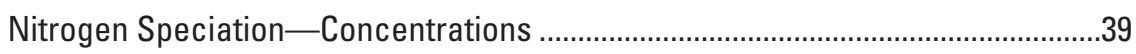

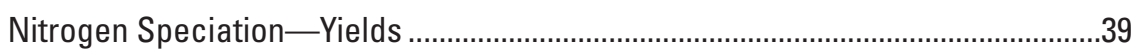

Summary

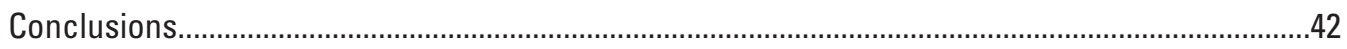

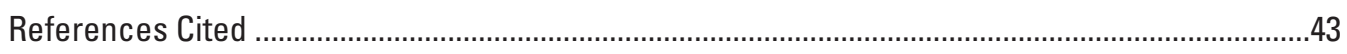

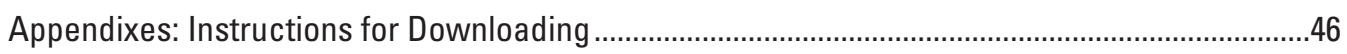




\section{Figures}

1. Map showing locations of selected Discovery Farms and Pioneer Farm in Wisconsin, monitored during water years 2003-8. Farms were classified into three geographic sections loosely corresponding to U.S. Environmental Protection Agency Level III Ecoregions and the major soil regions of Wisconsin to help clarify geographic setting and distinguishing physical features of each farm location.

2-7. Aerial view showing:

2. Discovery Farm SW1 showing basin and monitoring-station locations

3. Discovery Farm SW2 showing basin and monitoring-station locations ...................7

4. Pioneer Farm showing basin and monitoring-station locations .................................

5. Discovery Farm SE1 showing basin and monitoring-station locations ....................13

6. Discovery Farm NE1 showing basin and monitoring-station locations....................15

7. Discovery Farm NE2 showing basin and monitoring-station locations....................18

8. Photograph showing typical monitoring station used to quantify surface-runoff volume and to collect samples of runoff from small agricultural basins at edges of Discovery Farms and Pioneer Farm fields

9. Photograph showing example of equipment used to measure rainfall, wind speed and direction, air and soil temperature (in profile), relative humidity, solar radiation, and soil moisture (in profile) on each farm.

10. Bar graphs showing mean annual precipitation and percentage difference from 1971-2000 mean annual precipitation at nearby NOAA weather stations, Discovery Farms and Pioneer Farm, water years 2003-8. Snowfall liquid equivalent was estimated by using snowfall depth from nearby NOAA weather stations and a ratio of 14 inches of snowfall to 1 inch of liquid equivalent.

11. Bar graphs showing mean annual runoff and runoff as percentage of annual precipitation, Discovery Farms and Pioneer Farm, water years 2003-8.

12. Pie chart showing percentage of total runoff during low, medium, and high antecedent soil-moisture conditions for unfrozen-ground periods, Discovery Farm NE1, water years 2003-8. Soil-moisture percentage is volumetric, calculated by dividing the volume of water in the soil by the total volume of soil and multiplying the result by 100 . The maximum in most saturated soils is about 50 percent...

13. Boxplot showing distribution of mean monthly runoff for all 26 farm years of data, Discovery Farms and Pioneer Farm, water years 2003-8.

14. Pie chart showing mean annual runoff (inches per acre) and percent of total, by ground condition, Discovery Farms and Pioneer Farm, water years 2003-8

15. Bar graphs showing mean annual runoff and percentage of total runoff during frozen-ground periods, Discovery Farms and Pioneer Farm, water years 2003-8.........29

16. Boxplot showing distribution of event mean concentrations of suspended sediment in runoff during frozen- and unfrozen-ground periods, Discovery Farms and Pioneer Farm, water years 2003-8.

17. Bar graph showing mean annual suspended-sediment yield, Discovery Farms and Pioneer Farm, water years 2003-8.

18. Bar graph showing mean monthly suspended-sediment yield and runoff, Discovery Farms and Pioneer Farm, water years 2003-8. 
19. Boxplot showing distribution of event mean concentrations of total phosphorus in runoff during frozen- and unfrozen-ground periods, Discovery Farms and

Pioneer Farm, water years 2003-8.

20. Bar graph showing mean annual total-phosphorus yield, Discovery Farms and Pioneer Farm, water years 2003-8.

21. Pie chart showing mean annual phosphorus yield (pounds per acre) and percent of total, by ground condition and phosphorus species, Discovery Farms and Pioneer Farm, water years 2003-8.

22. Bar graph showing mean monthly particulate and dissolved-phosphorus yields and runoff, Discovery Farms and Pioneer Farm, water years 2003-8

23. Boxplot showing distribution of event mean concentrations of total nitrogen in runoff during frozen- and unfrozen-ground periods, Discovery Farms and Pioneer Farm, water years 2003-8.

24. Bar graph showing mean annual total-nitrogen yield, Discovery Farms and Pioneer Farm, water years 2003-8

25. Pie chart showing mean annual nitrogen yield (pounds per acre) and percent of total, by ground condition and nitrogen species, Discovery Farms and Pioneer Farm, water years 2003-8.

26. Bar graph showing mean monthly organic nitrogen, nitrate, and ammonium yields and runoff, Discovery Farms and Pioneer Farm, water years 2003-8

\section{Tables}

1-6. Crop and tillage type, manure-application information, and soil phosphorus levels for fields in the monitored basin at:

1. Discovery Farm SW1, water years 2005-7

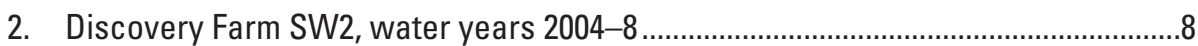

3. Pioneer Farm, water years 2003-8....................................................................

4. Discovery Farm SE1, water years 2006-8 ........................................................14

5. Discovery Farm NE1, water years 2004-8 …………..........................................16

6. Discovery Farm NE2, water years 2005-8 ……..................................................17

7. Constituents analyzed for Discovery Farms and Pioneer Farm edge-of-field runoff samples, water years 2003-8.

8. Farm name, USGS station information, abbreviated station name, drainage area, and period of record for Discovery Farms and Pioneer Farm edge-of-field monitoring stations, water years 2003-8

9. Abbreviated farm name, USGS station number and name used for collection of rainfall data, and NOAA station location and number used for published snowfall and 1971-2000 mean annual precipitation data

10. Annual runoff, in inches, and percentage of total runoff distributed between frozen- and unfrozen-ground periods, Discovery Farms and Pioneer Farm, water years 2003-8.

11. Selected summary statistics for runoff and precipitation at Discovery Farms and Pioneer Farm, 2003-8 


\section{Conversion Factors}

\begin{tabular}{lcl}
\hline \multicolumn{1}{c}{ Multiply } & By & \multicolumn{1}{c}{ To obtain } \\
\hline inch (in.) & Length & \\
inch (in.) & 2.54 & centimeter $(\mathrm{cm})$ \\
centimeter (cm) & 25.4 & millimeter (mm) \\
\hline & 0.3937 & inch (in.) \\
\hline acre & Area & \\
\hline & 0.4047 & hectare (ha) \\
\hline inch per acre (in/acre) & Rate or yield & \\
gallon per acre (gal/acre) & 6.276 & centimeter per hectare $(\mathrm{cm} / \mathrm{ha})$ \\
pound per acre (lb/acre) & 9.353 & liter per hectare $(\mathrm{L} / \mathrm{ha})$ \\
ton per acre (ton/acre) & 1.121 & kilogram per hectare $(\mathrm{kg} / \mathrm{ha})$ \\
\hline
\end{tabular}

Temperature in degrees Fahrenheit $\left({ }^{\circ} \mathrm{F}\right)$ may be converted to degrees Celsius $\left({ }^{\circ} \mathrm{C}\right)$ as follows:

${ }^{\circ} \mathrm{C}=\left({ }^{\circ} \mathrm{F}-32\right) / 1.8$

Horizontal coordinate information is referenced to the insert datum name North American Datum of 1927 (NAD27).

Concentrations of sediment and chemical constituents in water are given in milligrams per liter $(\mathrm{mg} / \mathrm{L})$. The filtration breakpoint defining dissolved constituents is given in micrometers $(\mu \mathrm{m})$. 



\title{
Precipitation-Runoff Relations and Water-Quality Characteristics at Edge-of-Field Stations, Discovery Farms and Pioneer Farm, Wisconsin, 2003-8
}

\author{
By Todd D. Stuntebeck, ${ }^{1}$ Matthew J. Komiskey, ${ }^{1}$ Marie C. Peppler, ${ }^{1}$ David W. Owens, ${ }^{1}$ and Dennis R. Frame ${ }^{2}$
}

\section{Abstract}

A cooperative study between the U.S. Geological Survey, the University of Wisconsin (UW)-Madison Discovery Farms program (Discovery Farms), and the UW-Platteville Pioneer Farm program (Pioneer Farm) was developed to identify typical ranges and magnitudes, temporal distributions, and principal factors affecting concentrations and yields of sediment, nutrients, and other selected constituents in runoff from agricultural fields. Hydrologic and water-quality data were collected year-round at 23 edge-of-field monitoring stations on 5 privately owned Discovery Farms and on Pioneer Farm during water years 2003-8. The studied farms represented landscapes, soils, and farming systems typical of livestock farms throughout southern Wisconsin. Each farm employed a variety of soil, nutrient, and water-conservation practices to help minimize sediment and nutrient losses from fields and to improve crop productivity. This report summarizes the precipitation-runoff relations and water-quality characteristics measured in edge-of-field runoff for 26 "farm years" (aggregate years of averaged station data from all 6 farms for varying monitoring periods). A relatively wide range of constituents typically found in agricultural runoff were measured: suspended sediment, phosphorus (total, particulate, dissolved reactive, and total dissolved), and nitrogen (total, nitrate plus nitrite, organic, ammonium, total Kjeldahl and total Kjeldahldissolved), chloride, total solids, total suspended solids, total volatile suspended solids, and total dissolved solids.

Mean annual precipitation was 32.8 inches for the study period, about 3 percent less than the 30 -year mean. Overall mean annual runoff was 2.55 inches per year (about 8 percent of precipitation) and the distribution was nearly equal between periods of frozen ground (54 percent) and unfrozen ground (46 percent). Mean monthly runoff was highest during two periods: February to March and May to June. Ninety percent of annual runoff occurred between January and the end of June.

\footnotetext{
U.S. Geological Survey, Middleton, Wisconsin

${ }^{2}$ University of Wisconsin-Madison Discovery Farms program, Pigeon Falls, Wisconsin
}

Event mean concentrations of suspended sediment in runoff during unfrozen-ground periods were significantly higher $(\mathrm{p}<0.05)$ than those during frozen-ground periods. Mean annual suspended-sediment yields ranged from about 3 to nearly 5,000 pounds per acre (lb/acre), with a mean yield of $667 \mathrm{lb} /$ acre. Ninety percent of suspended sediment was yielded in runoff during unfrozen-ground periods. May and June alone contributed more than 80 percent of the overall yield.

Phosphorus concentrations and yields were also affected by the ground conditions at the time of runoff; however, unlike suspended sediment, phosphorus was usually available for transport in runoff regardless of ground condition. Mean annual total-phosphorus yields ranged from 0.03 to $7.0 \mathrm{lb} / \mathrm{acre}$, with a mean yield of about $2.0 \mathrm{lb} / \mathrm{acre}$. Nitrogen in runoff followed similar patterns to phosphorus in that concentrations were highest during unfrozen-ground periods, yields were highest during months of highest runoff, and speciation was affected by the ground conditions at the time of runoff. Mean annual total-nitrogen yields ranged from 0.11 to $19.2 \mathrm{lb} / \mathrm{acre}$, and the mean was $7.2 \mathrm{lb} / \mathrm{acre}$. Mean monthly total-nitrogen yields were strongly correlated with mean monthly total-phosphorus yields $\left(\mathrm{r}^{2}=0.92\right)$, indicating that the sources of nitrogen and phosphorus in runoff were likely similar.

Analysis of runoff, concentration, and yield data on annual, monthly, and seasonal time scales, when combined with precipitation, soil moisture, soil temperature, and on-farm field-activity information, revealed conditions in which runoff was most likely. The analysis also revealed the effects that field conditions and the timing of field-management activities - most notably, manure applications and tillage — had on the quantity and quality of surface runoff from agricultural fields. 


\section{Introduction}

The Wisconsin Agricultural Stewardship Initiative (WASI) began in May 2000 (Wisconsin Legislative Fiscal Bureau, 2001) to help Wisconsin farmers meet environmental and economic challenges. This initiative established the University of Wisconsin (UW)-Madison Discovery Farms program (Discovery Farms) and the UW-Platteville Pioneer Farm program (Pioneer Farm). The Discovery Farms program (http://www.uwdiscoveryfarms.org/, accessed February 2, 2011) conducts environmental-systems research on privately owned farms across the State, representing a variety of farming enterprises and management systems, to demonstrate the adoptability and practicality of agricultural management practices in diverse landscape settings. The Pioneer Farm program (http://www.uwplatt.edu/pioneerfarm/, accessed February 2, 2011) conducts environmental-systems research in a controlled setting on the UW-Platteville research farm to test the adoptability and financial ramifications of agricultural practices and technologies that may be impractical, both financially and environmentally, to implement on privately owned farms.

The U.S. Geological Survey (USGS) Wisconsin Water Science Center worked cooperatively with the Discovery Farms and Pioneer Farm programs and in partnership with the Wisconsin Department of Natural Resources and the Sand County Foundation to collect hydrologic and water-quality data on a year-round basis at 23 edge-of-field stations on 5 Discovery Farms and on Pioneer Farm. Data were collected as part of a broad study to identify the ranges and magnitudes, temporal distributions, and principal factors affecting concentrations and yields of sediment, nutrients, and other selected constituents in runoff from agricultural fields.

Meteorological and farm-management data also were collected on the five Discovery Farms and on Pioneer Farm. Meteorological stations were established at each farm to measure precipitation, soil temperature (in profile), and soil moisture. Discovery Farms and Pioneer Farm personnel collected cropping data (planting date, harvest date, crop yield), soils data (soil texture and permeability, slope, phosphorus and nitrogen content), manure- and fertilizer-application data (manure or fertilizer type, rate applied, nutrient content, application method), and other pertinent information. Meteorological and farm-management data were combined with edge-offield data to determine important factors affecting agricultural runoff in Wisconsin.

\section{Purpose and Scope}

This report summarizes hydrologic and water-quality data collected at the 23 edge-of-field monitoring stations during water years ${ }^{1} 2003-8$. Ranges and magnitudes, temporal distributions, and principal factors affecting concentrations and yields of sediment, nutrients, and other selected constituents in runoff from agricultural fields are discussed. This report supports the Discovery Farms and Pioneer Farm programs in their missions to conduct environmental-systems research and to demonstrate the adoptability and practicality of agricultural management practices. The information presented here will be used, in part, to determine what on-farm modifications of agricultural practices could be recommended to producers to minimize potential adverse impacts on the environment.

Specific report objectives include describing (1) the landscapes and farm-management practices of the monitored farms; (2) relations between rainfall and runoff from edges of agricultural fields; (3) concentrations and yields of sediment, nutrients, and other selected constituents in runoff from edges of agricultural fields; and (4) environmental conditions and farm-management practices that can affect the magnitude and temporal distribution of runoff and of constituent concentrations and yields measured from edges of agricultural fields.

\section{Data Limitations}

The data presented in this report were used to reach generalized interpretations of the most likely factors affecting runoff and constituent yields at edges of fields in a variety of farm settings. These factors included weather-such as precipitation amount and intensity and snowfall amounts - and farm-management characteristics - such as cropping rotation, time of tillage, timing and rate of manure applicationsamong many others. These factors were not consistent among the farms. For example, it was common for precipitation amounts and intensities to vary widely among farms, even on the same day.

Although these inconsistencies were expected as part of this broad-based study, the differences or similarities in runoff amounts and (or) constituent yields among farms were likely due to a combination of factors and not just a result of the farming system alone (such as disc tillage versus no-till, for example). Caution should therefore be used if the data are used to determine whether a particular farming system yielded higher runoff amounts or sediment and nutrient yields than another. A thorough examination and careful application of the data - including, for example, normalization for weather variability — would be required to evaluate whether differences in runoff amounts and (or) constituent yields were a function of the farming systems alone. Such investigations and guidance are beyond the scope of this report.

\footnotetext{
1 "Water year" in USGS reports is the 12-month period October 1 through September 30 . The water year is designated by the calendar year in which it ends and which includes 9 of the 12 months.
} 


\section{Study Area and Farm Descriptions}

A total of 23 edge-of-field monitoring stations were established in the southern half of Wisconsin on 5 Discovery Farms and Pioneer Farm (fig. 1). On each farm, the monitoring stations were established in small basins draining agricultural fields that were deemed to be representative of the crops, slopes, soils, and management characteristics of that farm. To help clarify the geographic setting and distinguishing physical features, the farms were classified into three sections. Section locations and extents were determined primarily to separate the farms spatially but also to loosely correspond to U.S. Environmental Protection Agency (USEPA) Level III Ecoregions (U.S. Environmental Protection Agency, 2007; Griffith and Omernik, 2009) and the major soil regions of Wisconsin (Hole and others, 1968). Each Discovery Farm was designated by an abbreviation for its respective section location for use throughout the report.

The southwest section is part of the unglaciated or Driftless Area of Wisconsin, where the landscape is typified by relatively flat ridges and valleys separated by steep hillslopes (Martin, 1965; Schmidt, 1987; Walker and Krug, 2003, Juckem and others, 2008). Ridge soils are typically clayey, hillslope soils are typically sandy, and valley soils are typically loamy. Soils can vary from clayey to sandy over short distances, but variations are generally related to topographic position and underlying geology. The three monitored farms in this section are in the far southern part of the Driftless Area, where slopes are typically lower and soils are less varied than in the northern parts.

The southeast section is part of the Southeast Till Plains, where the landscape is generally flatter than the Driftless Area because of past glaciations. Soils and soil permeability are heterogeneous, ranging from sandy to clayey in texture and from high to low in permeability. The extent and distribution of soil is less systematic than in the Driftless Area.

Much the northeast section is classified by the USEPA as part of the Southeast Till Plains; however, a significant area is representative of the Lake Michigan Clay Plain, known for its red, clayey soils and low permeabilities. Subsurface-tile drainage is a common agricultural practice used to facilitate water drainage from poorly drained soils and internally drained basins (Ruark and others, 2009). The northeast section is also known for its karst geology, where rapid downward movement of surface water through shallow soils and sinkholes into fractured bedrock is common (Erb and Stieglitz, 2007).

Agriculture is the predominant land use in all three sections. Row and forage crops (mostly corn, soybeans, and alfalfa) are widely grown to support Wisconsin's large dairy industry (Wisconsin Department of Natural Resources, 1998; Reese and others, 2002; U.S. Department of Agriculture, 2008).

The climate of Wisconsin is typically classified as continental, with some modification by Lake Michigan (Wisconsin State Climatology Office, 2009a). Although precipitation and air temperature can differ substantially from southern to northern Wisconsin, the climate typical of the farms highlighted in this report is relatively similar among them.

Average annual precipitation (based on 1971-2000) in the southern half of Wisconsin is approximately 30-35 in., with the highest averages in extreme southern Wisconsin and a general decrease northward (National Oceanic and Atmospheric Administration, 2009; Wisconsin State Climatology Office, 2009a). Most precipitation falls during summer (June-August), occasionally in heavy, convective-type storms with high rainfall intensities (Huff and Angel, 1992). The next-highest precipitation periods are spring and fall (MarchMay and September-November, respectively), when frontal systems generally cause more widespread rain showers of lower intensity (Peters, 1997). Precipitation amounts are the least during winter (December-February). Although rain can occur in southern Wisconsin in winter, snowfall is much more common: average annual snowfall ranges from 40 to 50 in. (Moran and Hopkins, 2002), and the annual duration of snow cover in southern Wisconsin averages 85 days (Wisconsin State Climatology Office, 2009b).

Although average, seasonal, and daily air temperatures vary widely across the study area, the 1971-2000 average annual air temperature in the southern half of Wisconsin was about $46^{\circ} \mathrm{F}$ (National Oceanic and Atmospheric Administration, 2009). Summer air temperatures average between $65^{\circ} \mathrm{F}$ and $72^{\circ} \mathrm{F}$, with the warmer temperatures typical in far southern areas. Winter air temperatures average between $10^{\circ} \mathrm{F}$ and $20^{\circ} \mathrm{F}$, with colder temperatures in the north. Slightly warmer winter air temperatures are common in the east, nearest Lake Michigan. Subfreezing and alternating freeze-thaw conditions can extend from September to May, the months of the average first and last frost, respectively (Koss and others, 1988).

\section{Discovery Farm SW1}

Discovery Farm SW1 is a pasture-based, rotationally grazed, certified organic dairy farm in southern Iowa County, Wis. (fig. 2). During the monitoring period (water years 2005-7), the farm operation included 110 milk cows and additional young stock. The primary crops grown on the farm were corn, oats or barley (small grain), and alfalfa/grass hay. Approximately 75 percent of the corn was harvested for grain and the remainder harvested as silage. The cropping rotation was typically 1 year of corn, 1 year of small grain plus alfalfa/ grass new seeding, then 2 to 3 years of productive hay.

Crop and soil management were influenced by the certified organic production status, as well as by shallow soils with limestone bedrock near the soil surface on some areas of the farm. Organic farming certification dictated that tillage and crop rotation be utilized for weed control rather than herbicides. Tillage methods included moldboard plow, chisel plow, disk, field cultivator, rotary hoe, and row cultivator. Crops were planted into fields where surface residue from previous crops was typically minimal. 


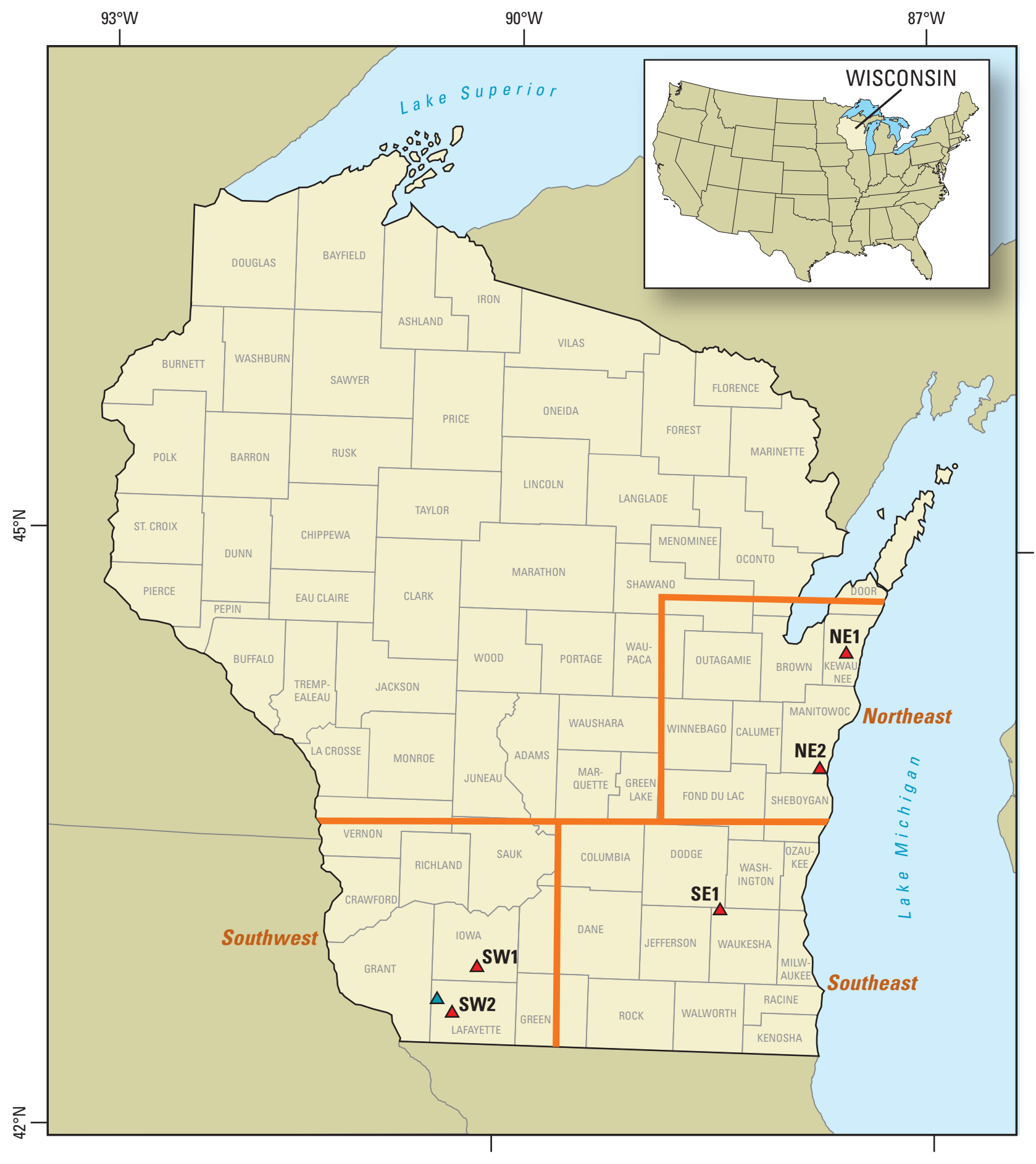

\section{EXPLANATION}

$\Delta$ Discovery Farms

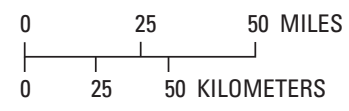

$\Delta$ Pioneer Farm

Section boundary and section name

Figure 1. Locations of selected Discovery Farms and Pioneer Farm in Wisconsin, monitored during water years 2003-8.

Farms were classified into three geographic sections loosely corresponding to U.S. Environmental Protection Agency Level III Ecoregions (U.S. Environmental Protection Agency, 2007; Griffith and Omernik, 2009) and the major soil regions of Wisconsin (Hole and others, 1968) to help clarify geographic setting and distinguishing physical features of each farm location. 


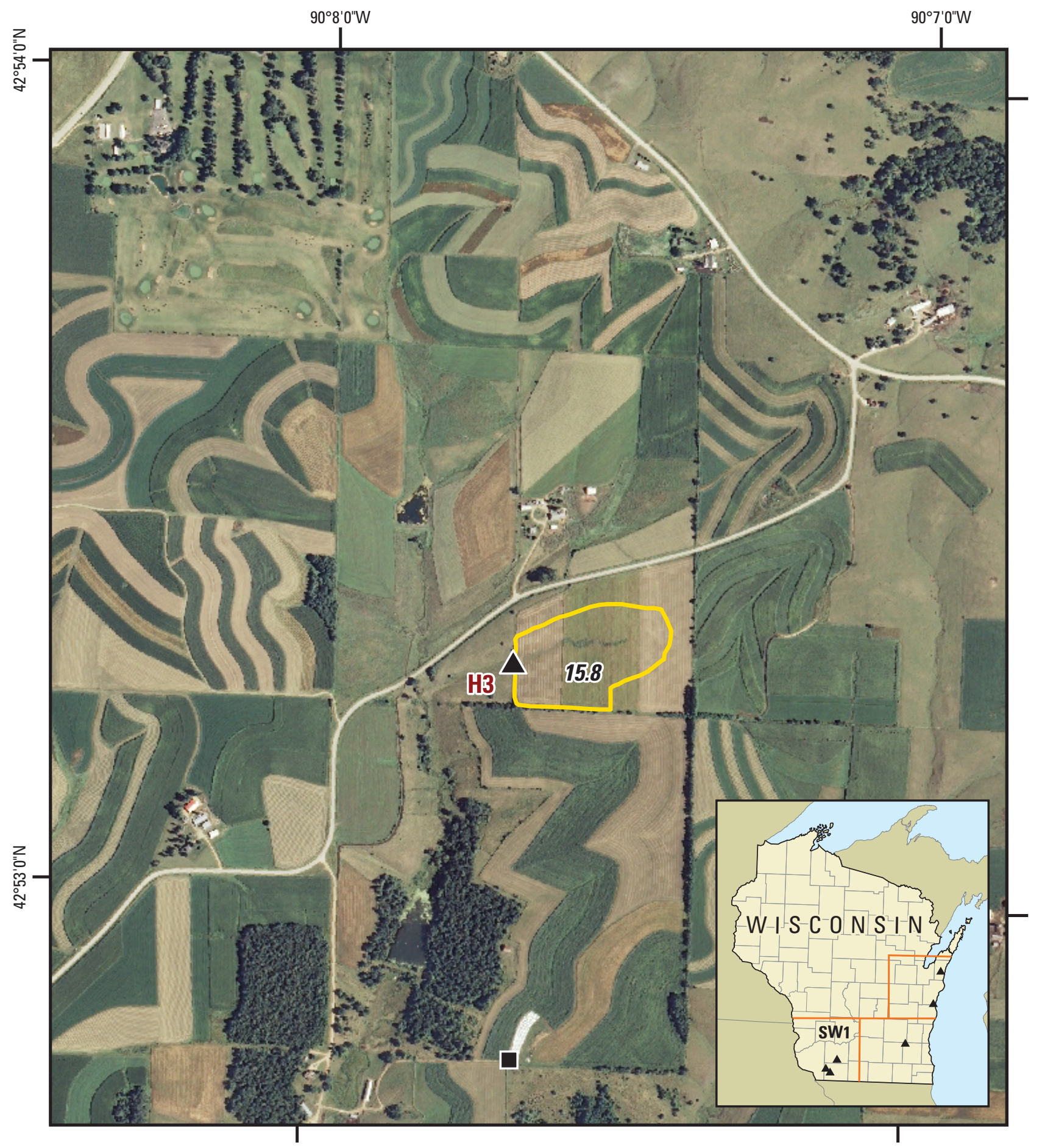

\section{EXPLANATION}

H3 Edge-of-field station and identifier

Base from 2008 National Agricultural Imagery Program (U.S. Department of Agriculture, 2008)
- Meteorlogical station
5.0 Basin boundary and area in acres

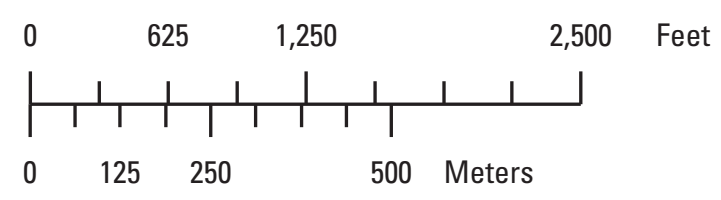

Figure 2. Aerial view of Discovery Farm SW1 showing basin and monitoring-station locations. 
Soils on the farm are classified primarily as Dodgeville silt loam, a fine, silty loam with moderately low permeability typically found in areas underlain by dolomite or limestone bedrock (U.S. Department of Agriculture, Natural Resources Conservation Service, 2009). Rugged areas of the farm with shallow soils were maintained in grass pasture. The farm had 140 acres of open pastureland, divided into 33 paddocks that were rotationally grazed by dairy cattle and heifers. Areas of some paddocks were quite steep, and depths to limestone bedrock were shallow. Soil- and water-conservation practices on the monitored fields included contour field layout, contour strips, grassed waterways, and a conservation crop rotation.

Nutrients were applied to approximately 230 acres of cropland in accordance with an approved nutrient-management plan based on crop phosphorus needs. Although organicapproved commercial fertilizers were periodically applied to the fields, most of the crop nutrients were those supplied by a combination of legume/hay rotation and livestock-manure application. Cows remained on pasture throughout the growing season, depositing manure as they grazed the paddocks. During winter months and periods of short feed supplies, cattle were fed in freestall hoop barns. Manure was scraped, loaded, and removed from barns as necessary. All manure was surface applied at a rate of approximately 15-20 ton/acre. Typically, all cropland received one application of manure over a 4-year rotation. Cropping, tillage, manure-management, and soil-test phosphorus data were collected by Discovery Farms personnel and the producer throughout the monitoring period (table 1).

One edge-of-field monitoring station (H3) was installed in July 2004 to measure surface-runoff volumes and to collect samples of runoff from a grassed waterway that drained a small, 15.8-acre agricultural basin with slopes ranging from 2 to 8 percent (fig. 2). The basin consisted of seven agronomic fields that were planted in either corn or alfalfa throughout the monitoring period.

\section{Discovery Farm SW2}

Discovery Farm SW2 is a beef-finishing operation in west-central Lafayette County, Wis. (fig. 3). During the monitoring period (water years 2004-8), the farm operation included two 300-head-capacity beef-finishing feedlots (a total of about 600 head). The primary crops grown on the farm were corn and soybeans, which were planted directly into crop residue from the previous year. Approximately 75 percent of the corn was harvested for grain and the remainder harvested as silage. Cornstalk residue was removed from most fields harvested for grain and was subsequently used for cattle bedding within the feedlots. The bedding was recycled back to the fields as feedlot manure was applied to help meet crop nutrient needs. The 3 -year crop rotation was typically 2 years of corn followed by 1 year of soybeans.

Crop and soil management at the farm were influenced by the single-pass, direct-planting system (no-till), where crops were planted into 50 percent surface residue remaining from the previous crop year. Cropland soils, which had not been tilled for approximately 20 years, were classified primarily as Tama silt loam: a fine, silty, well-drained loam formed in loess (U.S. Department of Agriculture, Natural Resources Conservation Service, 2009). Soil- and water-conservation practices on the monitored fields included the single-pass, direct-planting system; surface-residue management; contour field layout; grassed waterways, and drive-over terraces.

Nutrients were applied to approximately 800 acres of cropland in accordance with an approved nutrient-management plan based on crop phosphorus needs. No starter fertilizer was applied at planting for either corn or soybeans. When corn was planted, commercial nitrogen was applied on a fieldby-field basis, either in multiple applications (preplanting plus mixed with herbicides) or all at once with herbicides, depending on what the previous crop had been and whether livestock manure was applied. No commercial phosphorus was applied to either crop.

Table 1. Crop and tillage type, manure-application information, and soil phosphorus levels for fields in the monitored basin at Discovery Farm SW1, water years 2005-7.

[\%, percent; nm, not measured]

\begin{tabular}{|c|c|c|c|c|c|}
\hline $\begin{array}{l}\text { Water } \\
\text { year }\end{array}$ & Station & $\begin{array}{l}\text { Crop type and percentage } \\
\text { of monitored basin }\end{array}$ & Tillage & $\begin{array}{l}\text { Month, type, and method } \\
\text { of manure application }\end{array}$ & $\begin{array}{l}\text { Soil phosphorus } \\
\text { (parts per million) }\end{array}$ \\
\hline 2005 & $\mathrm{H} 3$ & $65 \%$ corn, $35 \%$ alfalfa & $\begin{array}{l}\text { Multiple plow types } \\
\text { (multiple dates) }\end{array}$ & $\begin{array}{l}\text { Sept. \& Nov. (2004), Feb., Mar., Apr., } \\
\text { May; solid dairy; not incorporated }\end{array}$ & 29 (Spring 2004) \\
\hline 2006 & $\mathrm{H} 3$ & $65 \%$ alfalfa, $35 \%$ corn & $\begin{array}{l}\text { Multiple plow types } \\
\text { (multiple dates) }\end{array}$ & Mar.; solid dairy; not incorporated & $\mathrm{nm}$ \\
\hline 2007 & $\mathrm{H} 3$ & $55 \%$ alfalfa, $45 \%$ corn & $\begin{array}{l}\text { Multiple plow types } \\
\text { (multiple dates) }\end{array}$ & $\begin{array}{l}\text { Oct. \& Nov. (2006), May; solid dairy; } \\
\text { not incorporated }\end{array}$ & $\mathrm{nm}$ \\
\hline
\end{tabular}




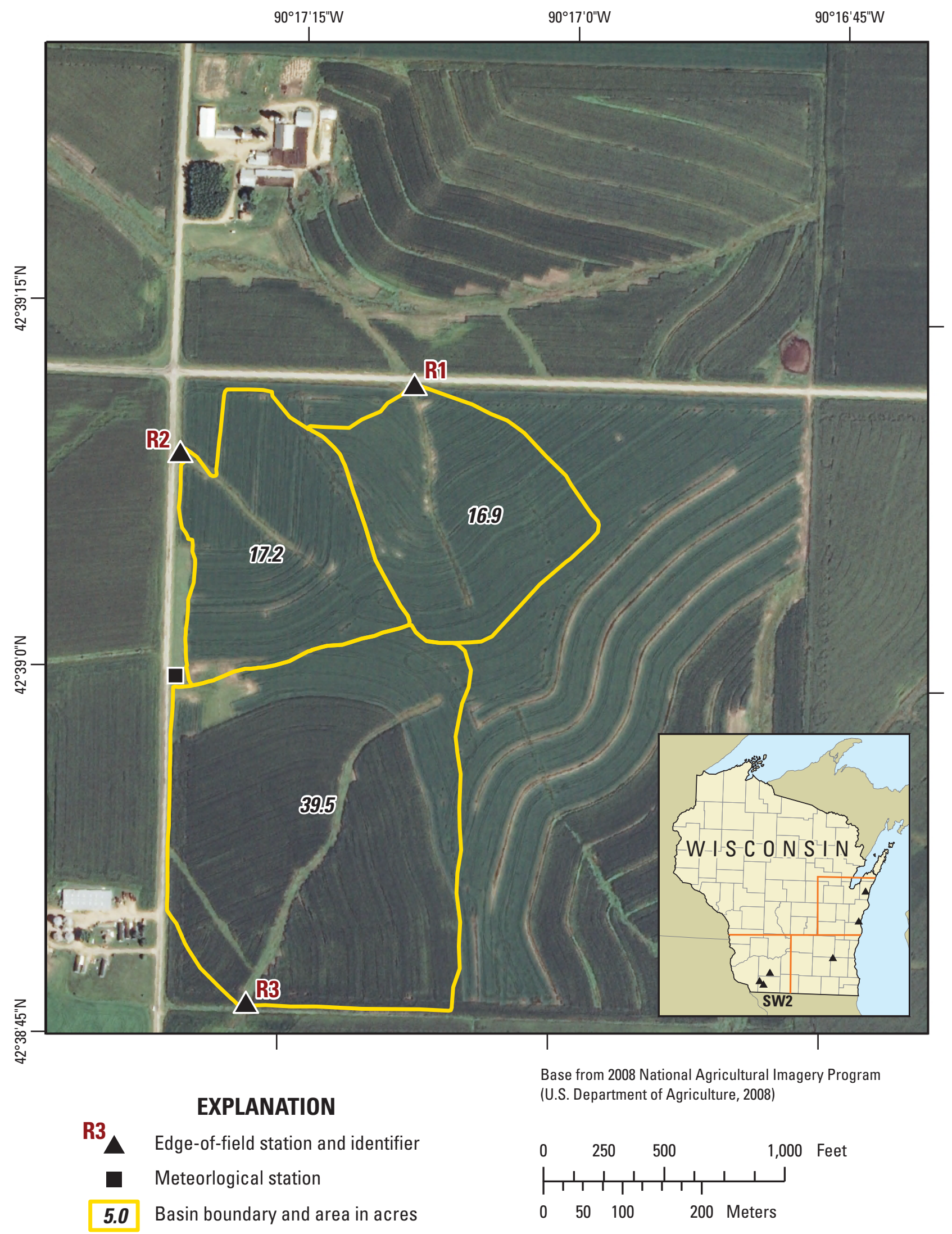

Figure 3. Aerial view of Discovery Farm SW2 showing basin and monitoring-station locations. 
Manure was scraped, loaded, and removed from the feedlots as necessary, approximately every other week. Manure collected from January to April and from October to December was immediately field spread. Manure collected from May to September was field stacked and applied in the fall. All manure was surface-applied at a rate of 13 to 15 ton/acre. During the first year of monitoring (2004), liquid dairy manure from a nearby farm also was surface-applied to fields. Cropping, tillage, manure-management, and soil-test phosphorus data were collected by Discovery Farms personnel and the producer throughout the monitoring period (table 2).

Three edge-of-field monitoring stations (R1, R2, and R3) were installed at Discovery Farm SW2 in November 2003 to measure surface-runoff volumes and to collect samples of runoff from grassed waterways that drain small agricultural basins with areas ranging from 16.9 to 39.5 acres and slopes ranging from 2 to 6 percent (fig. 3). Each basin consisted of parts of two agronomic fields that were planted in corn or soybeans throughout the monitoring period.

\section{Pioneer Farm}

Pioneer Farm is a mixed-livestock farm owned by the University of Wisconsin-Platteville, located in northwest Lafayette County, Wis. (fig. 4). During the monitoring period (water years 2003-8), the farm's dairy herd increased from approximately 90 milking cows to 130 after the addition of a new dairy facility. A swine-confinement facility was added in 2004 to hold a 60-sow herd and 1,400 wean-to-finish swine each year. A beef center and bull test station was also on the farm, with the capacity for a 200-head herd.

The primary crops grown on the farm were corn, alfalfa, and oats. The crop rotation was 3 years of corn, 1 year of oats, and then 3 years of alfalfa. In the transition from alfalfa to corn, the alfalfa was chemically killed in the fall and then the soil was finished and planted with corn in the spring. Approximately 70 to 80 percent of the corn was harvested as grain and the remainder harvested for silage. The farm had 53 acres of permanent pasture. Most of the productive soils on the farm were classified as Tama silt loam: a fine, silty, well-drained loam formed in loess (U.S. Department of Agriculture, Natural Resources Conservation Service, 2009). Soil- and waterconservation practices on the monitored fields included conservation tillage, grassed waterways, conservation-crop rotations, stripcropping, and terraces.

Table 2. Crop and tillage type, manure-application information, and soil phosphorus levels for fields in the monitored basins at Discovery Farm SW2, water years 2004-8.

[\%, percent; nm, not measured]

\begin{tabular}{|c|c|c|c|c|}
\hline Station & $\begin{array}{l}\text { Crop type and percentage } \\
\text { of monitored basin }\end{array}$ & Tillage & Month, type, and method of manure application & $\begin{array}{l}\text { Soil phosphorus } \\
\text { (parts per million) }\end{array}$ \\
\hline \multicolumn{5}{|c|}{2004} \\
\hline $\mathrm{R} 2$ & $100 \%$ corn & None & Sept. (2003), Feb.; liquid dairy; not incorporated & 63 (fall 2004) \\
\hline $\mathrm{R} 3$ & $75 \%$ soybeans, $25 \%$ corn & None & Nov. (2003); liquid dairy; not incorporated & 74 (fall 2004) \\
\hline $\mathrm{R} 2$ & $100 \%$ soybeans & None & Sept. \& Oct. (2004); solid beef; not incorporated & $\mathrm{nm}$ \\
\hline $\mathrm{R} 3$ & $75 \%$ corn, $25 \%$ soybeans & None & $\begin{array}{l}\text { Sept. \& Oct. (2004), Jan., Feb.; solid beef; not incorporated } \\
\text { Oct. (2004); liquid dairy; not incorporated }\end{array}$ & $\mathrm{nm}$ \\
\hline \multicolumn{5}{|c|}{2006} \\
\hline \multicolumn{5}{|c|}{2007} \\
\hline $\mathrm{R} 1$ & $100 \%$ corn & None & Oct. \& Dec. (2006), Mar.; solid beef; not incorporated & $\mathrm{nm}$ \\
\hline $\mathrm{R} 2$ & $100 \%$ corn & None & Oct. \& Dec. (2006), Mar.; solid beef; not incorporated & $\mathrm{nm}$ \\
\hline R3 & $75 \%$ soybeans, $25 \%$ corn & None & Oct. \& Dec. (2006); solid beef; not incorporated & $\mathrm{nm}$ \\
\hline \multicolumn{5}{|c|}{2008} \\
\hline $\mathrm{R} 1$ & $100 \%$ soybeans & None & None & 37 (fall 2008) \\
\hline $\mathrm{R} 2$ & $100 \%$ soybeans & None & None & 37 (fall 2008) \\
\hline $\mathrm{R} 3$ & $75 \%$ corn, $25 \%$ soybeans & None & Feb., solid beef; not incorporated & 49 (fall 2008) \\
\hline
\end{tabular}




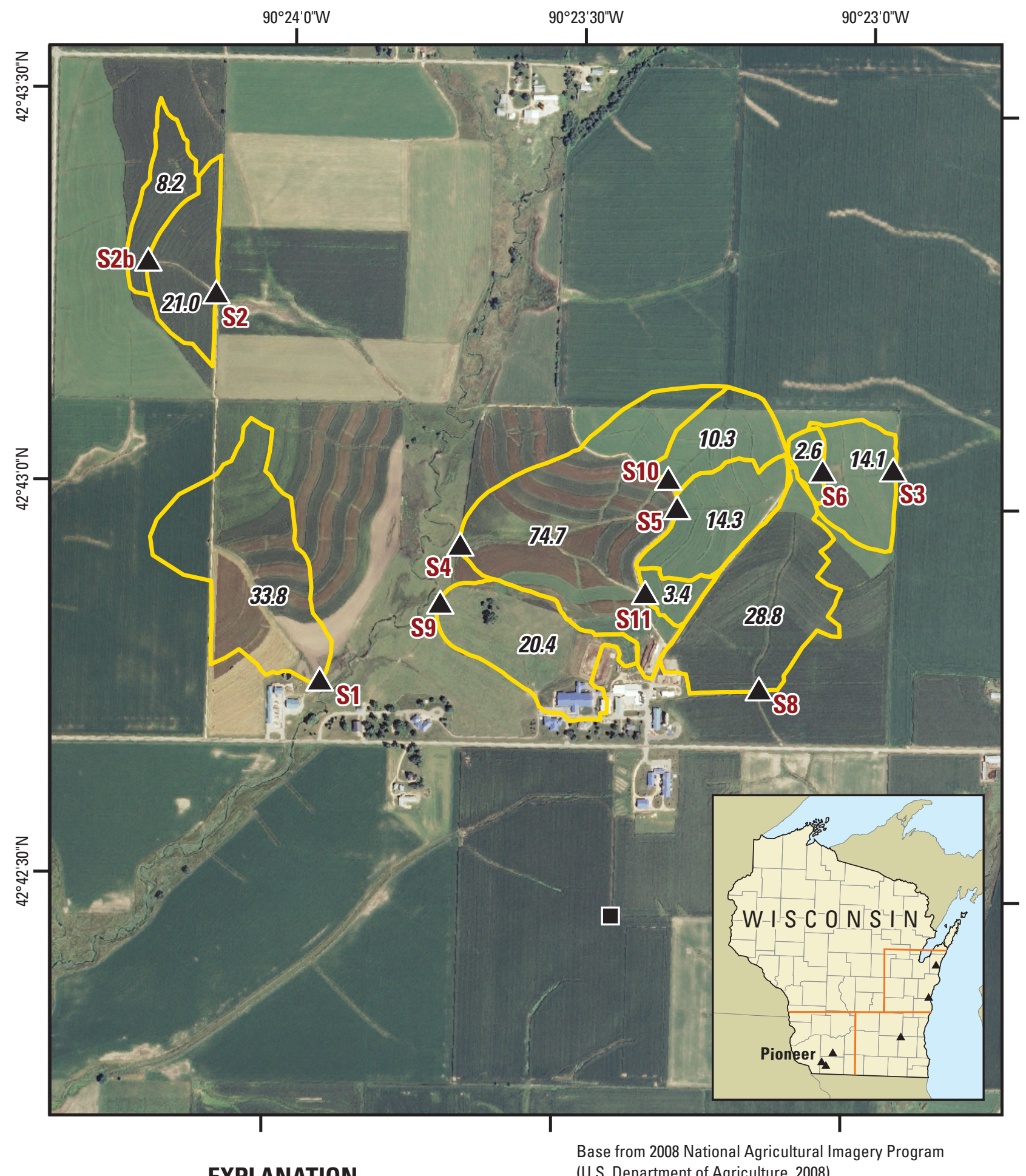

\section{EXPLANATION}

S1 Edge-of-field station and identifier

- Meteorological station

5.0 Basin boundary and area in acres (U.S. Department of Agriculture, 2008)

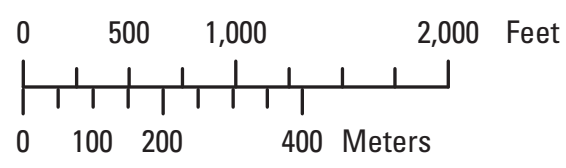

Figure 4. Aerial view of Pioneer Farm showing basin and monitoring-station locations. Noted acreage for each station includes all subbasin areas. 
Nutrients were applied to 313 acres of cropland in accordance with a comprehensive nutrient-management plan based on crop phosphorus and nitrogen needs. Most nutrient requirements were met with livestock-manure applications; however, chemical nitrogen was sometimes applied to provide additional nutrients without causing phosphorus enrichment in soils. Manure from the dairy operation was stored in a lined, earthen pit capable of 12 months of storage. Liquid manure from this pit was applied once per year in fall by using a hose-reel injection system at a typical rate of about $25,000 \mathrm{gal} / \mathrm{acre}$. Manure from the nondairying areas included solid-pack manure from the bull test station, beef center, heifer lots, and calf facility. These manures were composted and applied to fields to meet crop-nutrient needs or were sold offfarm. Manure from the swine center was actively composted in pits below the swine center with an in-floor, forced-aeration system and was managed similarly to the rest of the solid manure on the farm. Cropping, tillage, manure-management, and soil-test phosphorus data were collected by Pioneer Farm personnel throughout the monitoring period (table 3).

Eleven edge-of-field monitoring stations (S1-S6, S8-S11, and S2b) were installed at Pioneer Farm at various times beginning in March 2002 to measure surface-runoff volumes and to collect samples of runoff from grassed waterways that drain small agricultural basins with areas ranging from 2.6 to 74.7 acres and slopes ranging from 2 to 7 percent (fig. 4). Most of the monitored basins consisted of single-crop agronomic fields; however, basins S1, S4, S8, and S9 supported a combination of crop types. During the monitoring period, the fields were cropped in corn, alfalfa, oats, or a combination of the three.

Table 3. Crop and tillage type, manure-application information, and soil phosphorus levels for fields in the monitored basins at Pioneer Farm, water years 2003-8. - Continued

[\%, percent; nm, not measured]

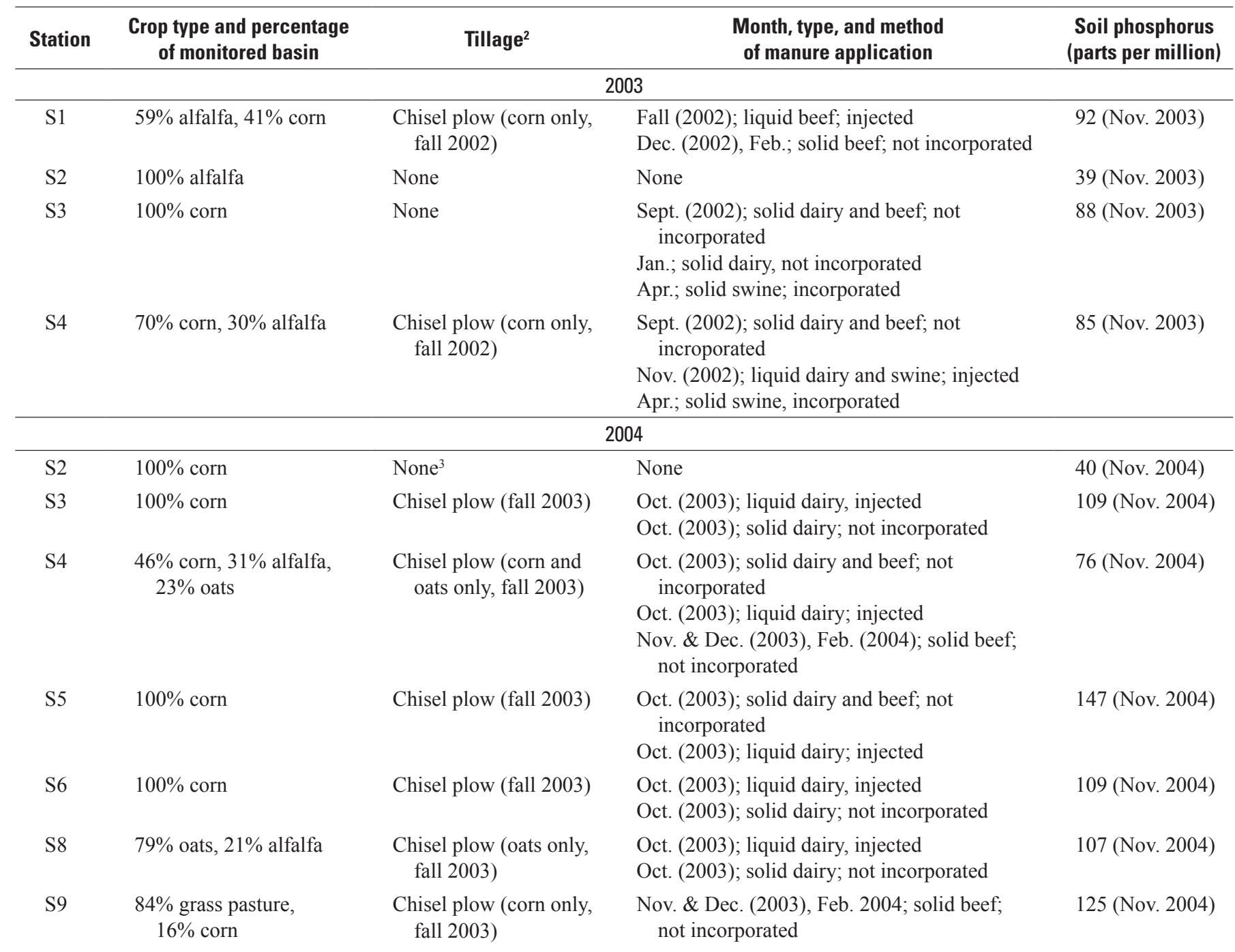


Table 3. Crop and tillage type, manure-application information, and soil phosphorus levels for fields in the monitored basins at Pioneer Farm, water years 2003-8.-Continued

[\%, percent; nm, not measured]

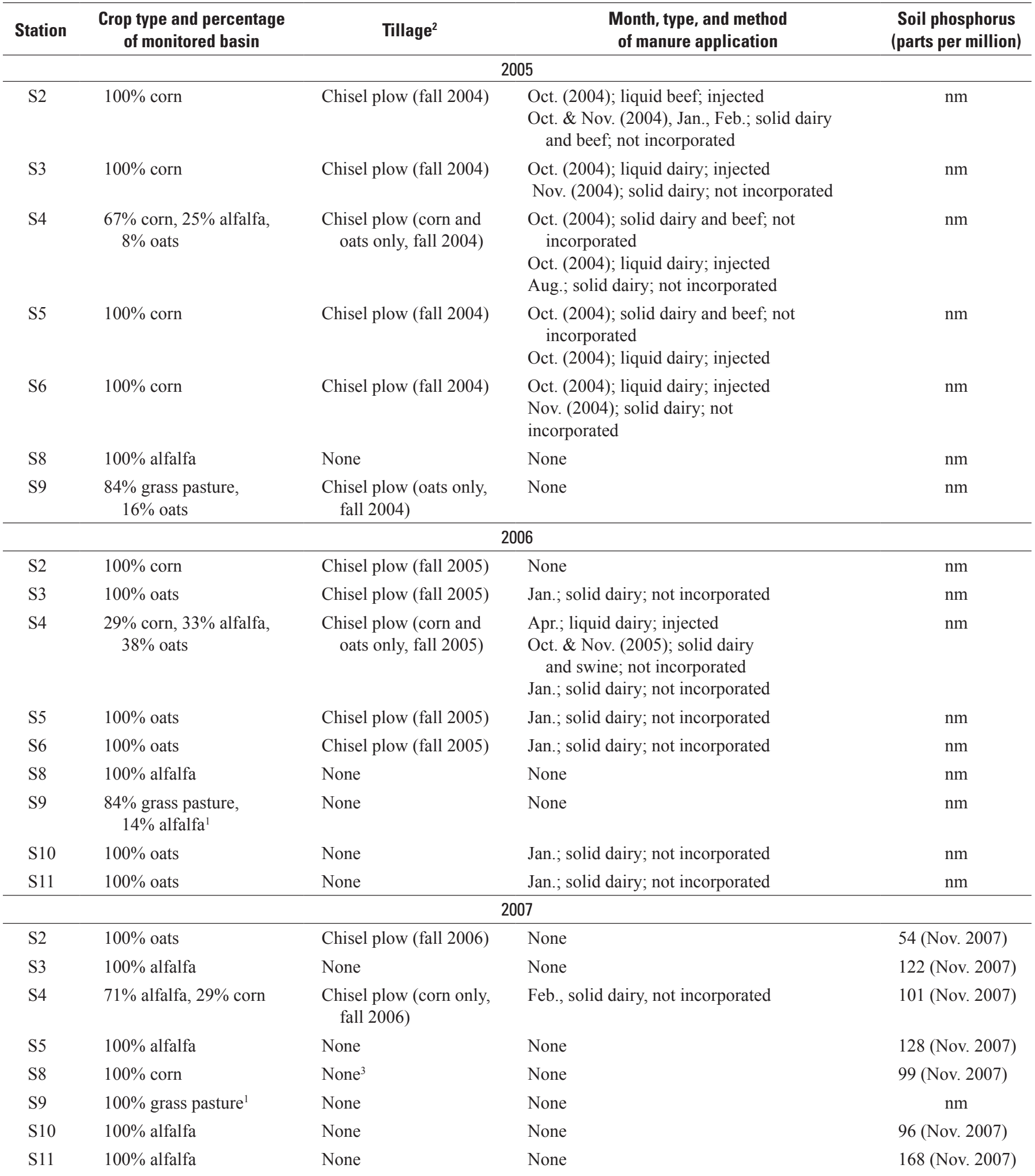


Table 3. Crop and tillage type, manure-application information, and soil phosphorus levels for fields in the monitored basins at Pioneer Farm, water years 2003-8.-Continued

$[\%$, percent; nm, not measured]

\begin{tabular}{cllll}
\hline Station & $\begin{array}{c}\text { Crop type and percentage } \\
\text { of monitored basin }\end{array}$ & \multicolumn{1}{c}{ Tillage $^{2}$} & \multicolumn{1}{c}{$\begin{array}{c}\text { Month, type, and method } \\
\text { of manure application }\end{array}$} & $\begin{array}{c}\text { Soil phosphorus } \\
\text { (parts per million) }\end{array}$ \\
\hline S2 & $100 \%$ corn & None $^{3}$ & None & $\mathrm{nm}$ \\
S2b & $100 \%$ corn & None & None & $\mathrm{nm}$ \\
S3 & $100 \%$ alfalfa & None & None & $\mathrm{nm}$ \\
S5 & $100 \%$ alfalfa & None & None & $\mathrm{nm}$ \\
S8 & $100 \%$ corn & Chisel plow (fall 2007) & Nov. (2007); liquid dairy; injected \\
& & & Sept.; solid dairy; not incorporated \\
S10 & $100 \%$ alfalfa & None & None & $\mathrm{nm}$ \\
S11 & $100 \%$ alfalfa & None & None & $\mathrm{nm}$ \\
\hline
\end{tabular}

${ }^{1}$ On-farm construction activities likely altered runoff characteristics.

${ }^{2}$ Before a crop was planted in the spring, fields were lightly tilled with a soil finisher.

${ }^{3}$ Alfalfa and oat fields transitioning into corn did not receive tillage before the corn was planted.

\section{Discovery Farm SE1}

Discovery Farm SE1 is a medium-sized, confinement dairy farm in northeast Waukesha County, Wis. (fig. 5). During the monitoring period (water years 2006-8), the farm consisted of approximately 320 milking cows, 285 dairy heifers, and 25 bulls. Primary crops grown on the farm were corn, soybeans, alfalfa, and winter wheat. Crop rotations were varied and were designed to meet livestock feed needs.

The farm cropped approximately 800 acres, which were managed with a no-till planting system. Although a wide variety of soil types are on the farm, the predominant soils within the monitored basin are Brookston and Theresa silt loams. Each soil is a fine, loamy soil with moderate permeability; however, the Brookston series is a poorly drained soil commonly found on low slopes, and crops on the soil commonly benefit from subsurface drainage (U.S. Department of Agriculture, Natural Resources Conservation Service, 2009). On some of the other soils on the farm (about 310 acres), irrigation was used. Soil- and water-conservation practices on the farm fields included no tillage, a variable crop rotation, and use of cover crops.
Nutrients were applied to 800 acres of cropland in accordance with an approved nutrient-management plan. Most nutrient requirements were met with livestock-manure applications, especially for the corn crops. The cows and heifers were housed in freestall barns, which were bedded with sand. The freestall manure was applied directly to the field or stored for a few days or weeks (30 to 40 days maximum). Water from the milking parlor (both washwater and wastewater) was kept separate from the freestall manure. Appropriate manure and legume credits were taken, and the balance of corn-nutrient needs was provided by use of starter fertilizer and urea, both of which were applied at the time of planting. No manure or fertilizer was applied to cropped land being used for soybeans. Cropping, tillage, manure-management, and soil-test phosphorus data were collected by Discovery Farms personnel and the producer throughout the monitoring period (table 4).

One edge-of-field monitoring station (KP3) was installed at Discovery Farm SE1 in May 2005 to measure surface-runoff volumes and to collect samples of runoff from a waterway that drained a small, 6.1-acre agricultural basin with slopes ranging from 2 to 6 percent (fig. 5). The basin consisted of parts of three agronomic fields that were planted in corn, soybeans, or alfalfa throughout the monitoring period. Numerous, randomized subsurface drainage tiles underlay the more poorly drained soils in low-lying areas. 


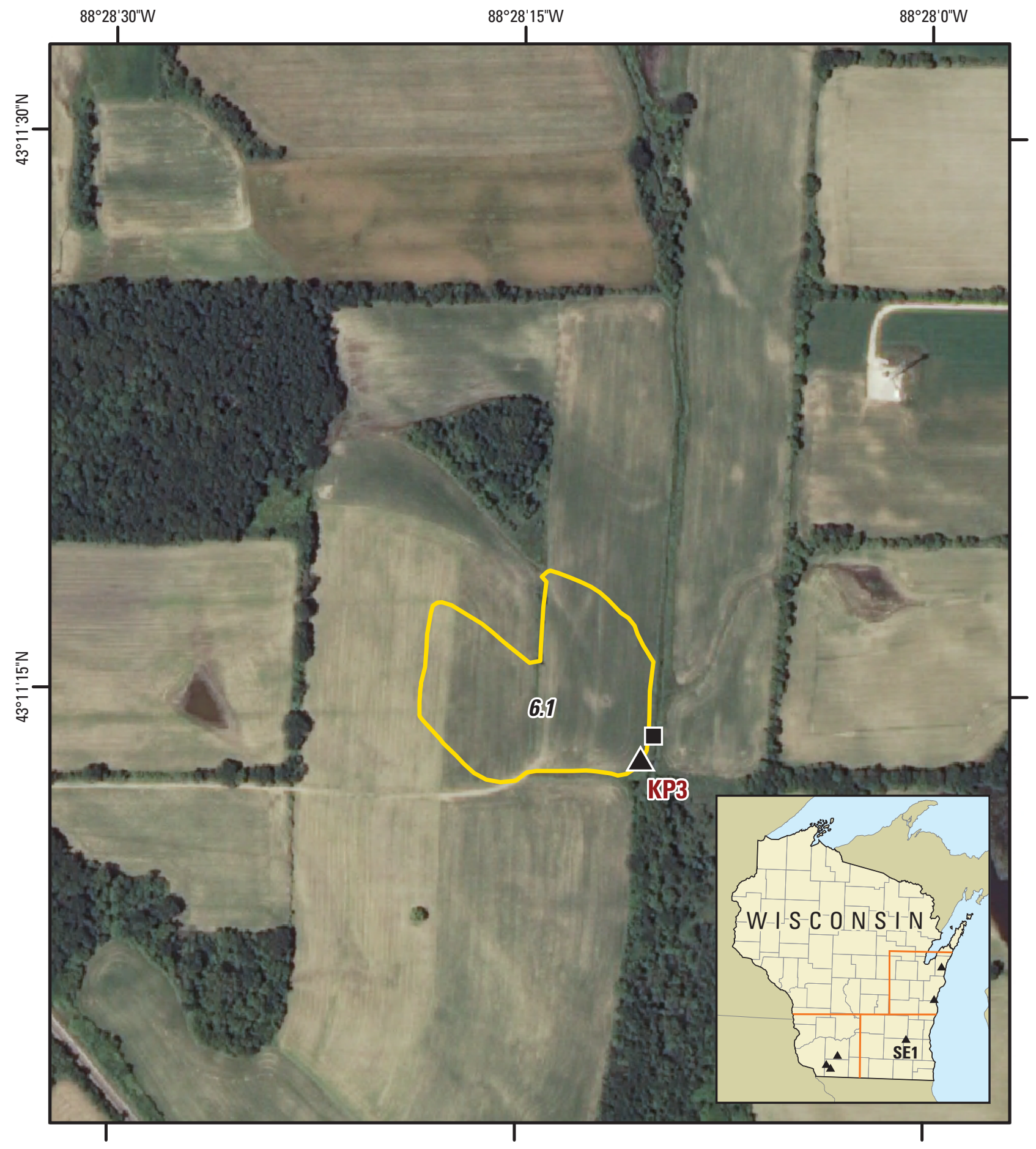

\section{EXPLANATION}

KP3 Edge-of-field station and identifier

- Meteorological station

5.0 Basin boundary and area in acres

Base from 2008 National Agricultural Imagery Program (U.S. Department of Agriculture, 2008)

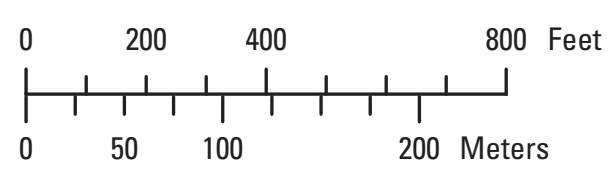

Figure 5. Aerial view of Discovery Farm SE1 showing basin and monitoring-station locations. 
Table 4. Crop and tillage type, manure-application information, and soil phosphorus levels for fields in the monitored basin at Discovery Farm SE1, water years 2006-8.

$[\%$, percent; nm, not measured $]$

\begin{tabular}{cccccc}
\hline $\begin{array}{c}\text { Water } \\
\text { year }\end{array}$ & Station & $\begin{array}{c}\text { Crop type and percentage } \\
\text { of monitored basin }\end{array}$ & Tillage & $\begin{array}{c}\text { Month, type, and method } \\
\text { of manure application }\end{array}$ & $\begin{array}{c}\text { Soil phosphorus } \\
\text { (parts per million) }\end{array}$ \\
\hline 2006 & KP3 & $75 \%$ corn, $25 \%$ soybeans & None & $\begin{array}{c}\text { Nov. \& Dec. (2005); semisolid dairy; } \\
\text { not incorporated }\end{array}$ \\
2007 & KP3 & $75 \%$ soybeans, $25 \%$ alfalfa & None & None & \\
2008 & KP3 & $75 \%$ corn, $25 \%$ alfalfa & None & Mar., Apr.; semisolid dairy; not incorporated & $\mathrm{nm}$ \\
\hline
\end{tabular}

${ }^{1}$ Soil phosphorus value for the largest field in the monitored basin, closest to the monitoring station.

\section{Discovery Farm NE1}

Discovery Farm NE1 is a large confinement dairy in central Kewaunee County, Wis. (fig. 6). During the monitoring period (water years 2004-8), the farm consisted of 1,400 milking cows; it was considered a Concentrated Animal Feeding Operation (CAFO) and was permitted to operate as such by the Wisconsin Department of Natural Resources. The primary crops grown were corn, alfalfa, and occasionally wheat. Most of the corn was harvested for silage, so corn residue left on the fields was minimal. The cropping rotation was typically 2 to 4 years of corn followed by 4 years of alfalfa. In the transition from corn to alfalfa, peas and oats were typically interseeded with alfalfa to enhance the initial feed value while the alfalfa became established. In the transition from alfalfa to corn, the alfalfa crop was usually chemically killed in the fall and then tilled in with a chisel plow; the fields were leveled before spring planting.

Crop and soil management were influenced by the soils and cool spring and summer climate due to the proximity of the farm to Lake Michigan. Soils are classified as Hortonville silt loam, which has relatively low permeability (U.S. Department of Agriculture, Natural Resources Conservation Service, 2009). Although officially classified as silt loam, soils at the farm have relatively high clay content. These clayey soils are representative of the northeast part of Wisconsin and are generally wetter in the spring and more slowly drying than other, less clayey soils in the State. To enhance crop production and improve field access, much of the cropland contains subsurface drainage. In addition to the wet soils, cool spring temperatures cause fieldwork to typically begin a week or more later than in areas of the State that are further south and more distant from Lake Michigan. Management practices to control erosion and improve crop production included conservation tillage, grassed waterways, subsurface tiles, and a conservation-crop rotation.

Nutrients were applied to approximately 1,800 acres of cropland in accordance with an approved nutrient-management plan based on crop phosphorus needs. Although some starter and supplemental fertilizers were applied to the fields during planting, most nutrient requirements for crops were met by applying livestock manure. All manure and wastewater generated on the farm was stored by means of an earthen lagoon system. This system included three large storage lagoons capable of 15 months of total storage, plus two smaller reception pits. Manure generated from freestall barns was typically scraped three times per day and gravity fed to the smaller reception pits. It was then pumped to the larger storage lagoons as needed, typically several times per year. One of the larger pits was used for solid-manure storage (mostly from sand bedding for the cows). Solid manure was typically surface applied to cropland three times per year at a rate of approximately 5 ton/acre and incorporated with a disc. Liquid manure was typically applied every summer to alfalfa after harvests and to corn every fall after harvest. Most the liquid manure was applied to the fields by using a hose-reel injection system at rates varying between 4,000 and 30,000 gal/acre. In general, lower application rates were used when liquid manure was applied to alfalfa, and higher application rates were used when liquid manure was applied to corn. Cropping, tillage, manure-management, and soil-test phosphorus data were collected by Discovery Farms personnel and the producer throughout the monitoring period (table 5).

Three edge-of-field monitoring stations (P1, P2, and P3) were installed at Farm NE1 in November 2004 to measure surface-runoff volumes and to collect samples of runoff from grassed waterways that drained small, agricultural basins with areas ranging from 13.2 to 22.1 acres and slopes ranging from 2 to 6 percent (fig. 6). The basins consisted of single-crop agronomic fields, which were planted in either corn or alfalfa throughout the monitoring period.

Each of the monitored basins contained subsurface drainage tiles to enhance crop production and improve field access. The subsurface-tile main in each field was in the monitored grassed waterway and passed beneath the surface-water monitoring stations. Additional, randomized laterals were located throughout the basin and were connected to the main in the waterway. 


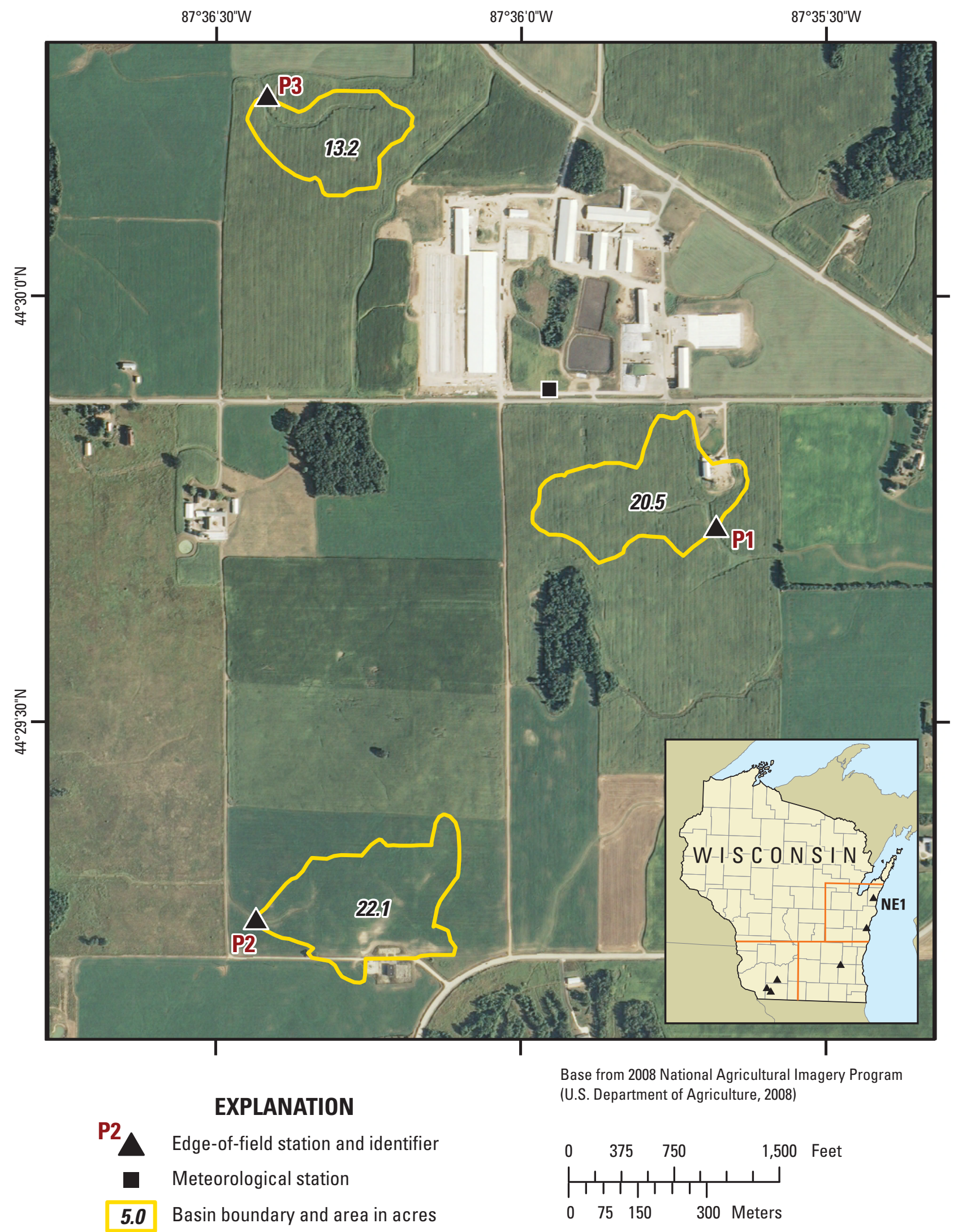

Figure 6. Aerial view of Discovery Farm NE1 showing basin and monitoring-station locations. 
Table 5. Crop and tillage type, manure-application information, and soil phosphorus levels for fields in the monitored basins at Discovery Farm NE1, water years 2004-8.

$[\%$, percent; nm, not measured]

\begin{tabular}{|c|c|c|c|c|}
\hline Station & $\begin{array}{l}\text { Crop type and percentage } \\
\text { of monitored basin }\end{array}$ & Tillage $^{1}$ & $\begin{array}{l}\text { Month, type, and method } \\
\text { of manure application }\end{array}$ & $\begin{array}{l}\text { Soil phosphorus } \\
\text { (parts per million) }\end{array}$ \\
\hline \multicolumn{5}{|c|}{2004} \\
\hline $\mathrm{P} 2$ & $100 \%$ alfalfa & None & Jul. \& Aug. (2003), Jul.; liquid dairy; not incorporated & 14 (Sept. 2004) \\
\hline \multicolumn{5}{|c|}{2005} \\
\hline $\mathrm{P} 1$ & $100 \%$ corn & Disc (spring 2005) & $\begin{array}{l}\text { Nov.- Dec. (2004), Jan.; solid dairy; not incorporated } \\
\text { Sept. (2004); liquid dairy; not incorporated }\end{array}$ & $\mathrm{nm}$ \\
\hline P3 & $100 \%$ corn & Disc (spring 2005) & $\begin{array}{l}\text { Sept. (2004); liquid dairy; not incorporated } \\
\text { Oct. (2004); liquid dairy; injected } \\
\text { May; solid dairy; incorporated }\end{array}$ & $\mathrm{nm}$ \\
\hline \multicolumn{5}{|c|}{2006} \\
\hline $\mathrm{P} 1$ & $100 \%$ corn & $\begin{array}{l}\text { Chisel plow } \\
\quad(\text { fall 2005) }\end{array}$ & Sept. (2005); liquid dairy; injected & $\mathrm{nm}$ \\
\hline $\mathrm{P} 2$ & $100 \%$ corn & $\begin{array}{l}\text { Chisel plow } \\
\quad(\text { fall 2005) }\end{array}$ & $\begin{array}{l}\text { Nov. (2005); liquid dairy; injected } \\
\text { May; solid dairy; incorporated }\end{array}$ & $\mathrm{nm}$ \\
\hline P3 & $100 \%$ corn & $\begin{array}{l}\text { Chisel plow } \\
\quad(\text { fall 2006) }\end{array}$ & $\begin{array}{l}\text { Oct. \& Nov. (2006) ; liquid dairy; injected } \\
\text { Nov. (2006); solid dairy; incorporated } \\
\text { Jan.; solid dairy; not incorporated }\end{array}$ & 64 (Oct. 2007) \\
\hline \multicolumn{5}{|c|}{2008} \\
\hline $\mathrm{P} 1$ & $100 \%$ corn & $\begin{array}{l}\text { Chisel plow } \\
\quad \text { (fall 2007) }\end{array}$ & Sept. (2007); liquid dairy; injected & 70 (Oct. 2009) \\
\hline $\mathrm{P} 3$ & $100 \%$ corn & $\begin{array}{l}\text { Chisel plow } \\
\quad(\text { fall 2007) } \\
\text { Disc (fall 2007) }\end{array}$ & $\begin{array}{l}\text { Oct. (2007); liquid dairy; injected } \\
\text { Nov. (2007); solid dairy; incorporated }\end{array}$ & 47 (Oct. 2009) \\
\hline
\end{tabular}

\footnotetext{
${ }^{1}$ Before a crop was planted in the spring, fields were lightly tilled with a soil finisher.
} 


\section{Discovery Farm NE2}

Discovery Farm NE2 is a pasture-based, rotationally grazed dairy farm in southeast Manitowoc County, Wis. (fig. 7). During the monitoring period (water years 2005-8), the farm operation consisted of approximately 425 milking cows, 400 young stock, and 200 stocker and feeder steers. Livestock grazed 600 acres of mixed-grass pastureland in a rotationally grazed paddock system. Excess feed grown on pastureland was harvested and stored in feed bunkers. The remaining 325 acres was cropped: $10-15$ percent of the total acreage was planted as corn, and 10-15 percent was planted as alfalfa. Cropped land did not stay in corn for more than 1 year, as it was seeded to pasture or alfalfa after a single growing season.

Crop and soil management were influenced by grazing and by soil type. Soils are classified primarily as Kewaunee loam, characterized by high clay content and moderately low or low permeability (U.S. Department of Agriculture, Natural Resources Conservation Service, 2009). Fields and pastures on the farm are underlain by extensive subsurface drainage tiles to reduce soil saturation.

Nutrients were applied to 925 acres of owned and (or) rented cropland in accordance with an approved phosphorusbased nutrient-management plan. Nutrient sources were primarily manure and wastewater, including manure from freestalls in the winter, pen-pack from calf housing, milkingparlor washwater, and holding-area washwater. Animals on the farm were housed only during the winter; therefore, approximately 50 percent of the manure produced was collected as liquid or pushed into a pile, and the rest was naturally deposited by the cows in the paddocks. Cropping, tillage, manuremanagement, and soil-test phosphorus data were collected by Discovery Farms personnel and the producer throughout the monitoring period (table 6).

Four edge-of-field monitoring stations (K3, K5, K7, and K8) were installed at Discovery Farm NE1 beginning in October 2004 to measure surface-runoff volumes and to collect samples of runoff from grassed waterways that drained small, agricultural basins with areas ranging from 5.0 to 17.6 acres and slopes ranging from 2 to 6 percent (fig. 7). Three of the stations (K5, K7, and K8) were in grassed pastures with varying amounts of animal traffic. Stations $\mathrm{K} 5$ and $\mathrm{K} 7$ were in pastures that also served as voluntary overwintering areas for the cattle during approximately December-March. Station K5 received the most animal traffic because it was closest to the farmstead. Station K8 was grazed only during the growing season and therefore received the least amount of traffic. Station K3 was in a grassed waterway draining a tilled field in a corn/soybean rotation; however, this field was not under the control of Discovery Farm NE2.

Basins K5 and K7 contained subsurface drainage tiles to enhance crop production and improve field access. The subsurface-tile main was in the monitored grassed waterway and passed beneath the surface-water monitoring stations. Additional, randomized laterals underlay the basin and were connected to the main in the waterway. Although it was not confirmed, it was suspected that basin K8 also contained subsurface tile drainage.

Table 6. Crop and tillage type, manure-application information, and soil phosphorus levels for fields in the monitored basins at Discovery Farm NE2, water years 2005-8.

[\%, percent]

\begin{tabular}{|c|c|c|c|c|}
\hline Station & $\begin{array}{l}\text { Crop type and } \\
\text { percentage of } \\
\text { monitored basin }\end{array}$ & Tillage & $\begin{array}{l}\text { Month, type, and method } \\
\text { of manure application }\end{array}$ & $\begin{array}{l}\text { Soil phosphorus } \\
\text { (parts per million) }\end{array}$ \\
\hline \multicolumn{5}{|c|}{2005} \\
\hline K3 & $100 \%$ soybeans $^{1}$ & Chisel plow (fall 2004) ${ }^{1}$ & Unknown & Unknown \\
\hline \multicolumn{5}{|c|}{2006} \\
\hline K3 & $75 \%$ corn, $25 \%$ alfalfa ${ }^{1}$ & Chisel plow (corn only, fall 2005) ${ }^{1}$ & Unknown & Unknown \\
\hline \multicolumn{5}{|c|}{2007} \\
\hline $\mathrm{K} 3$ & $75 \%$ corn, $25 \%$ alfalfa $^{1}$ & Chisel plow (corn only, fall 2006) & Unknown & Unknown \\
\hline K5 & Mixed-grass pasture & None & $\begin{array}{l}\text { Grazed or overwintered year round } \\
\text { May; liquid dairy; injected }\end{array}$ & 75 (Oct. 2007) \\
\hline K7 & Mixed-grass pasture & None & Grazed or overwintered year round & 110 (Oct. 2007) \\
\hline \multicolumn{5}{|c|}{2008} \\
\hline K5 & Mixed-grass pasture & None & Grazed or overwintered year round & 140 (Apr. 2009) \\
\hline K7 & Mixed-grass pasture & $\begin{array}{l}\text { Chisel plow (winter 2007) } \\
\text { Finished and reseeded (spring 2008) }\end{array}$ & $\begin{array}{l}\text { Grazed or overwintered from } \\
\text { Oct.-Nov. (2008) } \\
\text { Nov. (2008); liquid manure, injected }\end{array}$ & 95 (Apr. 2009) \\
\hline K8 & Mixed-grass pasture & None & Grazed spring to fall & $\begin{array}{l}39 \text { (Oct. 2007) } \\
24 \text { (Apr. 2009) }\end{array}$ \\
\hline
\end{tabular}

'Estimated; field not under the control of Discovery Farm NE2. 


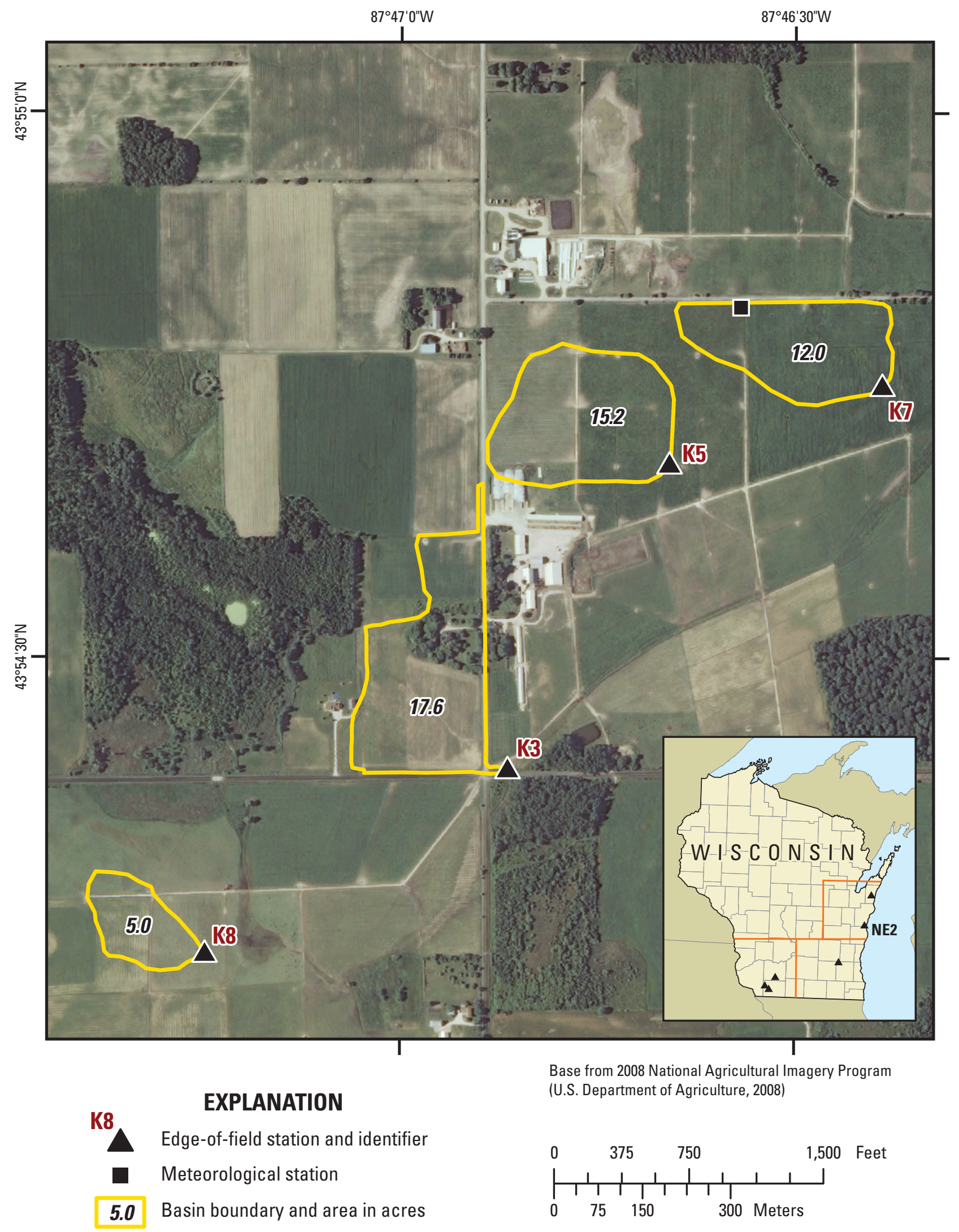

Figure 7. Aerial view of Discovery Farm NE2 showing basin and monitoring-station locations. 


\section{Methods}

\section{Data Collection}

The 23 monitoring stations were installed, maintained, and operated to quantify surface-runoff volume and to collect samples of runoff from small agricultural basins at edges of fields on the 6 farms between water years 2003 and 2008, according to the methods described in detail by Stuntebeck and others (2008). A short description of these methods follows.

$H$ flumes were used per standard USGS procedures (Garn, 2002) to continuously measure surface-runoff volumes (fig. 8). Automated refrigerated samplers were used to collect discrete 1-L samples during runoff events per methods similar to those described in the USGS Wisconsin Water Science Center quality-assurance plan (Richards and others, 2006).

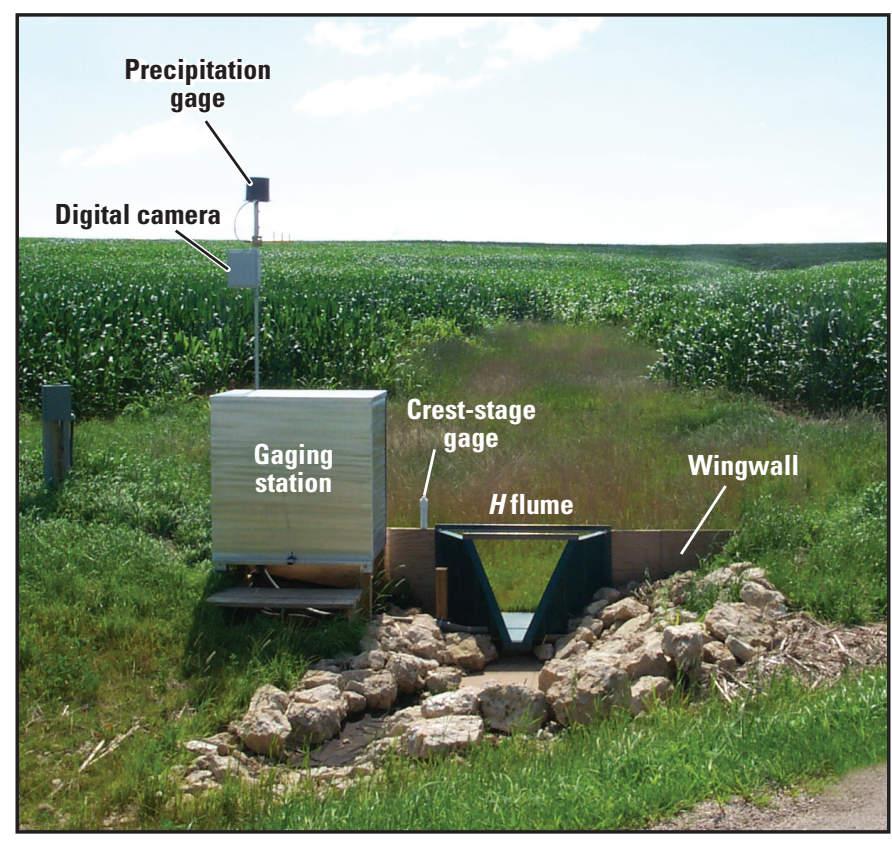

Figure 8. Typical monitoring station used to quantify surfacerunoff volume and to collect samples of runoff from small agricultural basins at edges of Discovery Farms and Pioneer Farm fields.

A discharge-weighted sample was then produced for each runoff event by calculating the percentage of the total runoffevent volume that each discrete sample represented, collecting appropriate aliquots from each discrete sample by using a churn splitter, and combining aliquots into one composite sample. The composite sample was analyzed by the Water and Environmental Analysis Laboratory in Stevens Point, Wis., for the constituents listed in table 7; standard methods were followed (National Environmental Methods Index, 2009). Particulate phosphorus, total nitrogen, and organic nitrogen were calculated from the analytical results.
Table 7. Constituents analyzed for Discovery Farms and Pioneer Farm edge-of-field runoff samples, water years 2003-8.

\begin{tabular}{|c|c|c|c|}
\hline Constituent & $\begin{array}{l}\text { Discovery } \\
\text { Farms } \\
\text { (Nov. 2003 - } \\
\text { Jan. 2005) }\end{array}$ & $\begin{array}{l}\text { Discovery } \\
\text { Farms } \\
\text { (Jan. 2005 } \\
\text { to 2008) }\end{array}$ & $\begin{array}{l}\text { Pioneer } \\
\text { Farm } \\
\text { May } 2003 \\
\text { to } 2008\end{array}$ \\
\hline Suspended sediment & $\mathrm{X}$ & $\mathrm{X}$ & $\mathrm{X}$ \\
\hline Total phosphorus & $\mathrm{X}$ & $\mathrm{X}$ & $\mathrm{X}$ \\
\hline $\begin{array}{l}\text { Dissolved reactive } \\
\text { phosphorus }\end{array}$ & $\mathrm{X}$ & $\mathrm{X}$ & $\mathrm{X}$ \\
\hline $\begin{array}{l}\text { Particulate } \\
\text { phosphorus }{ }^{1}\end{array}$ & $\mathrm{X}$ & $X$ & $\mathrm{X}$ \\
\hline Total nitrogen ${ }^{1}$ & $\mathrm{X}$ & $\mathrm{X}$ & $\mathrm{X}$ \\
\hline Nitrate plus nitrite & $\mathrm{X}$ & $\mathrm{X}$ & $\mathrm{X}$ \\
\hline Organic nitrogen ${ }^{1}$ & $\mathrm{X}$ & $\mathrm{X}$ & $\mathrm{X}$ \\
\hline Ammonium & $\mathrm{X}$ & $\mathrm{X}$ & $\mathrm{X}$ \\
\hline $\begin{array}{l}\text { Total Kjeldahl } \\
\text { nitrogen }\end{array}$ & $\mathrm{X}$ & $\mathrm{X}$ & $\mathrm{X}$ \\
\hline Chloride & $\mathrm{X}$ & $\mathrm{X}$ & $\mathrm{X}$ \\
\hline Total dissolved solids & & $\mathrm{X}$ & \\
\hline Total solids & $\mathrm{X}$ & & $\mathrm{X}$ \\
\hline Total suspended solids & $\mathrm{X}$ & & $\mathrm{X}$ \\
\hline $\begin{array}{l}\text { Total volatile } \\
\text { suspended solids }\end{array}$ & $\mathrm{X}$ & & $\mathrm{X}$ \\
\hline $\begin{array}{l}\text { Total Kjeldahl } \\
\text { nitrogen-dissolved }\end{array}$ & $\mathrm{X}$ & & $\mathrm{X}$ \\
\hline $\begin{array}{c}\text { Total dissolved } \\
\text { phosphorus }\end{array}$ & $\mathrm{X}$ & & $\mathrm{X}$ \\
\hline
\end{tabular}

${ }^{1}$ Calculated.

The results represent an event mean (or average) con centration for each runoff event; concentrations throughout the runoff events were likely variable, ranging both higher than and lower than the event mean concentration. Although concentrations in surface runoff delivered from field edges to streams and (or) lakes do not necessarily represent the concentrations found in the receiving water body, these measured concentrations can be an indication of potential changes in water quality of the receiving water body.

The method used to determine dissolved reactive phosphorus concentrations included acidification of the filtered sample before analysis. This was done to stabilize the sample because analyzing the sample within the recommended 48 hours was usually not possible. The USEPA refers to the analysis resulting from this preacidification as "dissolved hydrolyzable and orthophosphate." For simplicity, this analysis is referred to as "dissolved reactive phosphorus" throughout the report, because differences between the two methods are likely very small (Dick Stephens, University of Wisconsin-Stevens Point Water and Environmental Analysis Laboratory; and George Bowman, Wisconsin State Laboratory of Hygiene, written commun., 2009). 
Water-quantity and water-quality data were collected so that flow (discharge) data could be combined with waterquality data to calculate loads (methods described in Porterfield (1972)) and yields (losses) from edges of agricultural fields. Event mean concentrations were used to compute individual storm loads (pounds) and yields (pounds per acre) for all sampled runoff events. Concentrations were estimated for unsampled runoff events by using those determined for sampled events that were similar in total discharge, peak discharge, and season, among other factors. Annual loads and yields were calculated by summing the data for sampled and estimated events. Typically, greater than 90 percent of the annual flow was sampled, so the estimated fraction of the annual load or yield was small.

Sometimes the dates of station installation or removal resulted in the collection of a partial-water-year record. If the runoff volumes for unmonitored periods were likely to be zero or very low (based on data from monitored stations at that farm), then the data for the partial water year were included in this report without modification. If, however, runoff volumes for the unmonitored periods were likely to be substantial, then the data for that partial water year were excluded from this report. A list of the stations and their associated periods of record can be found in table 8 .

Rainfall and other meteorological data were collected at a monitoring station (hereafter called a meteorological station) at each farm so they could be used to interpret changes in water quantity and water quality. Tipping-bucket rain gages were used for estimates of rainfall. Additional measurements included wind speed, wind direction, air temperature, relative humidity, solar radiation, soil temperatures (at depths of 2, 5, $10,20,40$, and $80 \mathrm{~cm})$, and soil moisture $(30-\mathrm{cm}$ average and (or) at depths of 10, 20,30 and $50 \mathrm{~cm}$ ) (fig. 9).

Annual and monthly precipitation were computed for each farm by summing the rainfall measured at each tippingbucket rain gage and the snowfall liquid equivalent (SLE) determined from published snowfall data. Snowfall data were estimated from National Oceanic and Atmospheric Administration (NOAA) weather stations near each farm (table 9).

According to Baxter and others (2005), the average snowfall-to-liquid ratio for Wisconsin is approximately $14 \mathrm{in}$. of snowfall to $1 \mathrm{in}$. of liquid precipitation. Snowfall was multiplied by this ratio factor (0.0714) to compute SLE. Even though variations in snowfall between the NOAA weather stations and the farms were likely and actual SLE values probably varied from storm to storm, the annual and monthly estimates of SLE should be adequately representative of actual values for the purposes of this report.

\section{Data Presentation and Analysis}

Some of the data in this report were previously published in USGS annual Water Data Reports (WDR) (U.S. Geological Survey, 2005-9) and are available online from the National Water Information System (NWIS) at http://waterdata.usgs. gov/nwis. For completeness and ease of use, some of the previously published data have been included in this report.

Previously published data include daily, monthly, and annual rainfall and discharge data published in the WDR and more detailed, minute-by-minute data available in NWIS. Water-quality concentration data and runoff volumes for sampled storms were published in the WDR; the concentration data are also available in NWIS. Meteorological data, such as wind speed and direction, air temperature, soil temperature (in profile), relative humidity, solar radiation, and soil moisture (in profile), are available in NWIS.

Previously unpublished data include annual and seasonal constituent yields (for frozen- and unfrozen-ground periods). In addition, snowfall and SLE data were compiled for the farms by using data from nearby NOAA weather stations. Monthly and annual precipitation amounts (both measured rainfall and estimated SLE) and runoff volumes for individual farms and stations are in appendix 1, summary statistics of event mean constituent concentrations in runoff for individual farms are in appendix 2, annual runoff and constituent yields for individual farms and stations are in appendix 3 , averaged minimum, maximum, and mean annual constituent yields are in appendix 4, and averaged monthly runoff volumes, precipitation amounts, and constituent yields are in appendix 5 . (Appendixes are published separately, in electronic form. See back of report for information on downloading).

Data for each station are presented by water year (termed a "station year"), which extended from October 1 to September 30. Data for each farm are presented as the mean of all of the station data on a farm for a particular water year (termed a "farm year"). The number of stations monitored at a farm was variable from year to year (table 8). In total, there were 84 station years of runoff data (42 each at Discovery Farms and Pioneer Farm) and 81 station years of water-quality data (42 and 39 station years at Discovery Farms and Pioneer Farm, respectively). The station-year data were summarized to create 26 farm years of runoff and water-quality data.

Data are included for station years and farm years in the appendixes, but the primary focus of the manuscript is to describe farm-year data in order to simplify the report. In addition, summary statistics (overall mean annual suspended-sediment yield, for example) are included to provide information encompassing all of the data for all of the years. These statistics were computed by using the 26 farm years of data, rather than the station-year data, because of the unequal distribution of stations among the farms. Averaging all of the station-year data would have biased the results to be overly representative of some farms and insufficiently representative of others. 
Table 8. Farm name, USGS station information, abbreviated station name, drainage area, and period of record for Discovery Farms and Pioneer Farm edge-of-field monitoring stations, water years 2003-8.

[USGS, U.S. Geological Survey; X, full water year; P, partial-record water year, but data sufficient to include in monthly and annual statistics; significant runoff during unmonitored periods likely zero or minimal; N, partial-record water year, data are insufficient to include in monthly and annual statistics; (), number of complete months of monitoring for partial-record years]

\begin{tabular}{|c|c|c|c|c|c|c|c|c|c|c|}
\hline \multirow{2}{*}{ Farm } & \multirow{2}{*}{$\begin{array}{c}\text { USGS } \\
\text { station number }\end{array}$} & \multirow{2}{*}{ USGS station name and location } & \multirow{2}{*}{$\begin{array}{l}\text { Abbreviated } \\
\text { station name }\end{array}$} & \multirow{2}{*}{$\begin{array}{c}\text { Basin } \\
\text { area } \\
\text { (acres) }\end{array}$} & \multicolumn{6}{|c|}{ Period of record (water year) } \\
\hline & & & & & 2003 & 2004 & 2005 & 2006 & 2007 & 2008 \\
\hline SW1 & 425318090074000 & Discovery Farms Waterway No. 1 near Mineral Point, Wis. & $\mathrm{H} 3$ & 15.8 & & N (3) & $\mathrm{X}$ & $\mathrm{X}$ & $\mathrm{X}$ & \\
\hline \multirow[t]{3}{*}{ SW2 } & 423912090170800 & Discovery Farms Waterway Site No. 1 near Belmont, Wis. & $\mathrm{R} 1$ & 16.9 & & $\mathrm{P}(10)$ & $\mathrm{X}$ & $\mathrm{X}$ & $\mathrm{X}$ & $\mathrm{X}$ \\
\hline & 423909090172100 & Discovery Farms Waterway Site No. 2 near Belmont, Wis. & $\mathrm{R} 2$ & 17.2 & & $\mathrm{P}(10)$ & $\mathrm{X}$ & $\mathrm{X}$ & $\mathrm{X}$ & $\mathrm{X}$ \\
\hline & 423846090171600 & Discovery Farms Waterway Site No. 3 near Belmont, Wis. & $\mathrm{R} 3$ & 39.5 & & $\mathrm{P}(10)$ & $\mathrm{X}$ & $\mathrm{X}$ & $\mathrm{X}$ & $\mathrm{X}$ \\
\hline \multirow[t]{11}{*}{ Pioneer } & 424245090235501 & U.W. Platteville Farms Site No. 1 near Platteville, Wis. & $\mathrm{S} 1$ & 33.8 & $\mathrm{X}$ & & & & & \\
\hline & 424314090240601 & U.W. Platteville Farms Site No. 2 near Platteville, Wis. & $\mathrm{S} 2$ & 21.0 & $\mathrm{X}$ & $\mathrm{X}$ & $\mathrm{X}$ & $\mathrm{X}$ & $\mathrm{X}$ & $\mathrm{X}$ \\
\hline & 424302090225601 & U.W. Platteville Farms Site No. 3 near Platteville, Wis. & S3 & 14.1 & $\mathrm{X}$ & $\mathrm{X}$ & $\mathrm{X}$ & $\mathrm{X}$ & $\mathrm{X}$ & $\mathrm{X}$ \\
\hline & 424256090234001 & U.W. Platteville Farms Site No. 4 near Platteville, Wis. & S4 & 74.7 & $\mathrm{X}$ & $\mathrm{X}$ & $\mathrm{X}$ & $\mathrm{X}$ & $\mathrm{X}$ & \\
\hline & 424259090231301 & U.W. Platteville Farms Site No. 5 near Platteville, Wis. & S5 & 14.3 & $\mathrm{~N}(7)$ & $\mathrm{X}$ & $\mathrm{X}$ & $\mathrm{X}$ & $\mathrm{X}$ & $\mathrm{X}$ \\
\hline & 424302090230301 & U.W. Platteville Farms Site No. 6 near Platteville, Wis. ${ }^{1}$ & S6 & 2.6 & $\mathrm{~N}(7)$ & $\mathrm{X}$ & $\mathrm{X}$ & $\mathrm{X}$ & & \\
\hline & 424245090231000 & U.W. Platteville Farms Site No. 8 near Platteville, Wis. & S8 & 28.8 & & $\mathrm{P}(10)$ & $\mathrm{X}$ & $\mathrm{X}$ & $\mathrm{X}$ & $\mathrm{X}$ \\
\hline & 424247090234500 & U.W. Platteville Farms Site No. 9 near Platteville, Wis. & S9 & 20.4 & & $\mathrm{X}$ & $\mathrm{X}$ & $\mathrm{X}$ & $\mathrm{X}$ & \\
\hline & 424302090231900 & U.W. Platteville Farms Site No. 10 near Platteville, Wis. & $\mathrm{S} 10$ & 10.3 & & & & $\mathrm{X}$ & $\mathrm{X}$ & $\mathrm{X}$ \\
\hline & 424253090232100 & U.W. Platteville Farms Site No. 11 near Platteville, Wis. & S11 & 3.4 & & & & $\mathrm{X}$ & $\mathrm{X}$ & $\mathrm{X}$ \\
\hline & 424317090241401 & U.W. Platteville Farms Site No. 2B near Platteville, Wis. & $\mathrm{S} 2 \mathrm{~b}$ & 8.2 & & & & & & $\mathrm{X}$ \\
\hline SE1 & 431112088281100 & Discovery Farms Waterway near Mapleton, Wis. & KP3 & 6.1 & & & $\mathrm{~N}(4)$ & $\mathrm{X}$ & $\mathrm{X}$ & $\mathrm{X}$ \\
\hline \multirow[t]{3}{*}{ NE1 } & 442944087354100 & Discovery Farms Waterway Site No. 1 near Kewaunee, Wis. & $\mathrm{P} 1$ & 20.5 & & $\mathrm{P}(11)$ & $\mathrm{X}$ & $\mathrm{X}$ & $\mathrm{X}$ & $\mathrm{X}$ \\
\hline & 442916087362600 & Discovery Farms Waterway Site No. 2 near Kewaunee, Wis. & $\mathrm{P} 2$ & 22.1 & & $\mathrm{P}(11)$ & $\mathrm{X}$ & $\mathrm{X}$ & & \\
\hline & 443012087362500 & Discovery Farms Waterway Site No. 3 near Kewaunee, Wis. & P3 & 13.2 & & $\mathrm{P}(11)$ & $\mathrm{X}$ & $\mathrm{X}$ & $\mathrm{X}$ & $\mathrm{X}$ \\
\hline \multirow[t]{4}{*}{ NE2 } & 408544206 & Centerville Creek Tributary No. 1 near Cleveland, Wis. & K3 & 17.6 & & & $X$ & $\mathrm{X}$ & $\mathrm{P}(7)$ & \\
\hline & 435441087463900 & Discovery Farms Waterway No. 1 near Cleveland, Wis. & K5 & 15.2 & & & & & $\mathrm{P}(11)$ & $\mathrm{X}$ \\
\hline & 435444087462300 & Discovery Farms Waterway No. 2 near Cleveland, Wis. & K7 & 12.0 & & & & & $\mathrm{P}(11)$ & $\mathrm{X}$ \\
\hline & 435414087471400 & Discovery Farms Waterway No. 3 near Cleveland, Wis. & K8 & 5.0 & & & & & & $\mathrm{X}$ \\
\hline
\end{tabular}

${ }^{1}$ Water-quantity data only. 


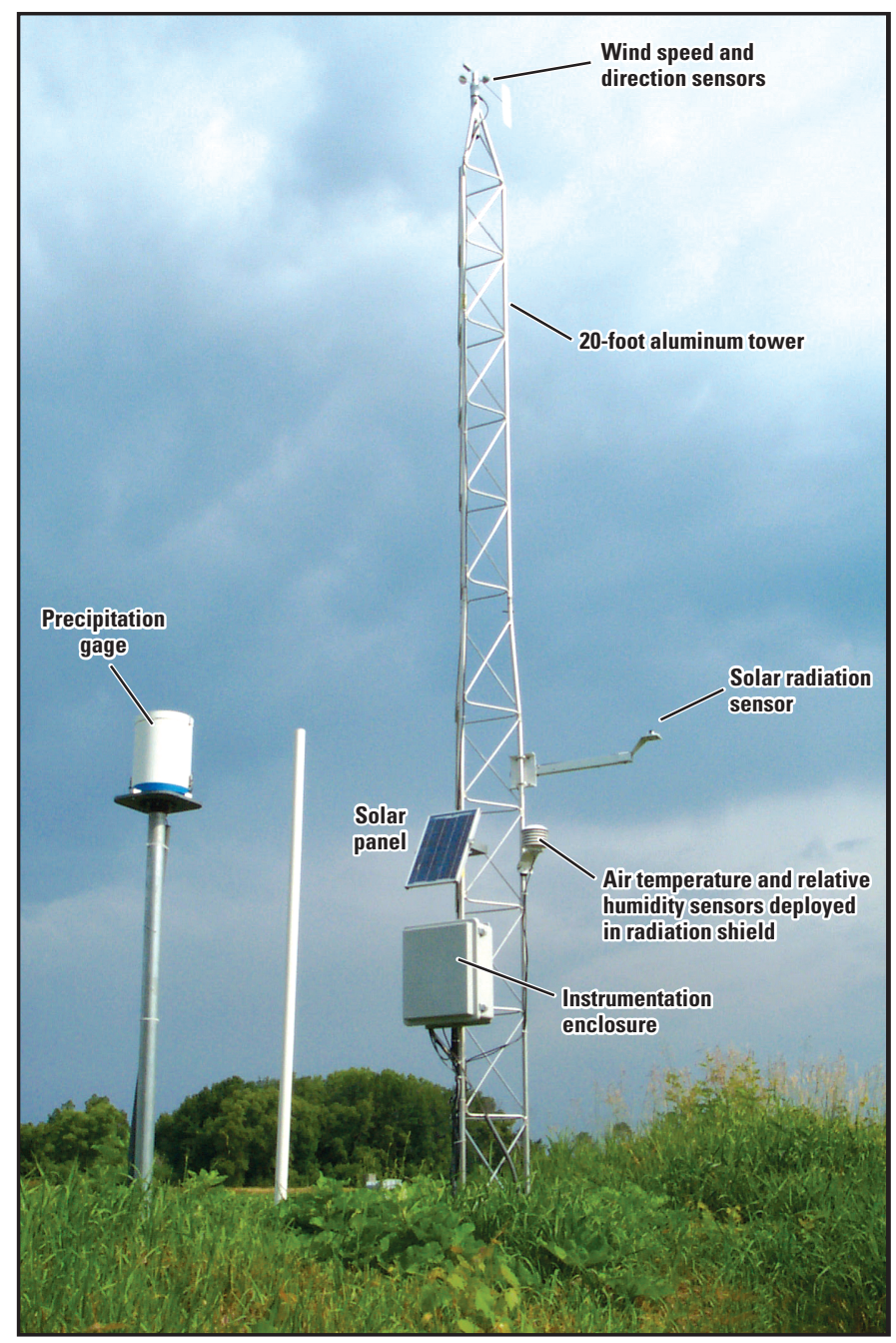

Figure 9. Example of equipment used to measure rainfall, wind speed and direction, air and soil temperature (in profile), relative humidity, solar radiation, and soil moisture (in profile) on each farm.

Table 9. Abbreviated farm name, USGS station number and name used for collection of rainfall data, and NOAA station location and number used for published snowfall and 1971-2000 mean annual precipitation data.

[USGS, U.S. Geological Survey; NOAA, National Oceanic and Atmospheric Administration; UW, University of Wisconsin]

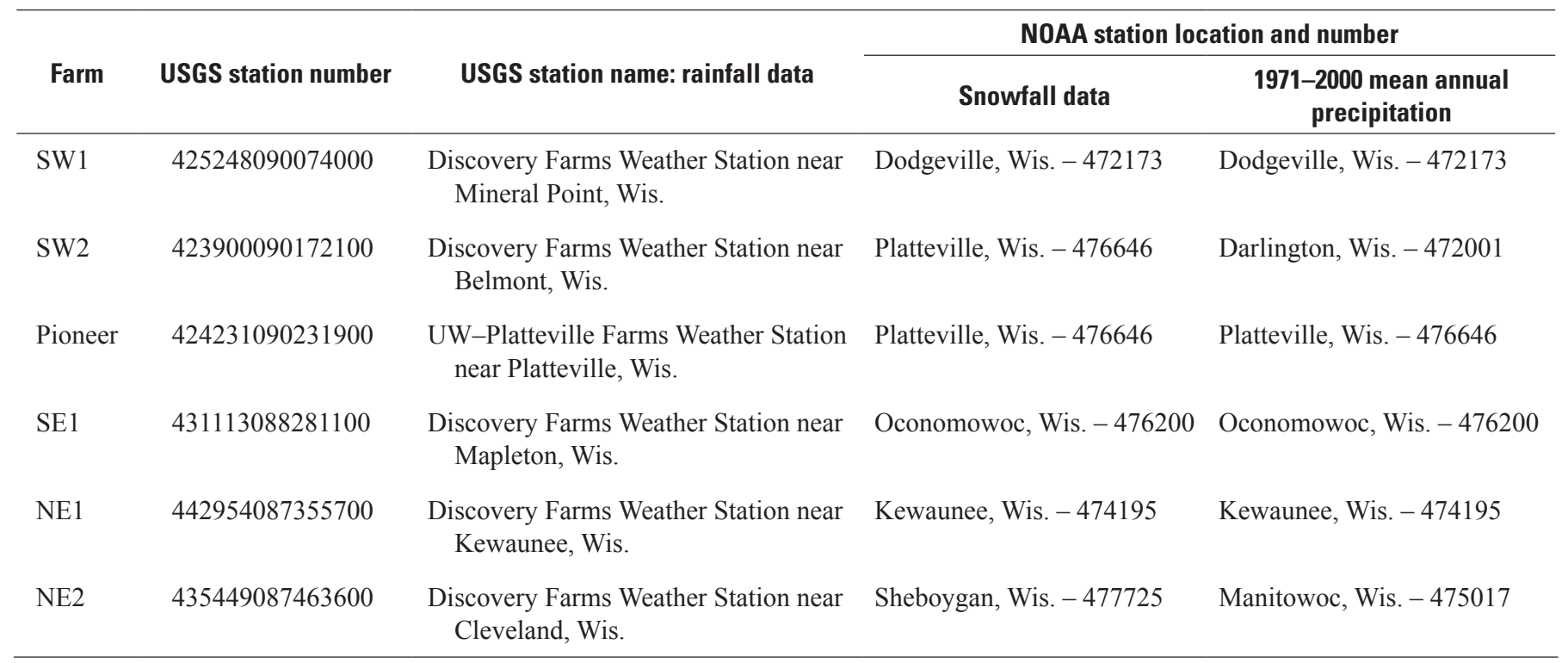


In the appendixes of this report, both mean and median statistics are used to describe central tendencies in concentration and yield data. In the manuscript and figures, however, median values are used to describe concentration data, whereas mean values are used to describe yield data. Concentration data are summarized in the manuscript to describe differences or similarities among farms for frozen and unfrozen ground. In general, there were greater than 20 concentrations for each condition, and the data are highly skewed; therefore, the best descriptor of central tendency for these data is the median concentration (Ott and Longnecker, 2001; Selbig and others, 2004). However, because of the comparatively few data points for annual-yield data (one value per station per condition per year), the median-yield value had a tendency to minimize the importance of any relatively low or relatively high yields at some farms. The mean-yield statistic was inclusive of all the values observed and therefore a better representative of the central tendency of the data than was the median.

For the most part, data in the report have been separated into frozen- and unfrozen-ground periods in order to describe differences or similarities in runoff volumes, constituent concentrations, or yields that may have resulted from these different ground conditions. Frozen-ground periods were defined to be those in which soil temperatures at the meteorological station at each respective farm were $32^{\circ} \mathrm{F}$ or less at any depth. The soil at $2 \mathrm{~cm}$ depth was always the first to freeze, whereas the deepest frozen depth was usually the last to thaw. Differences in soil temperatures between fields and meteorological stations were not evaluated.

Event mean constituent concentrations, runoff durations, and peak runoff discharges were compared for frozen- and unfrozen-ground periods using the nonparametric Mann-Whitney statistical test at the 5-percent significance level. Summary statistics of event mean constituent concentrations were also computed for annual and frozen- and unfrozen-ground periods for each farm. In cases where concentrations were less than the detection limit, the nonparametric Kaplan Meier statistical method described in Helsel (2005) was used to compute statistics.

\section{Precipitation-Runoff Relations}

Precipitation and runoff data were collected to examine the magnitude, distribution, and frequency of runoff and to determine selected factors affecting runoff from agricultural fields. To support these objectives, precipitation and runoff data were collected year-round and were thus inclusive of both frozen- and unfrozen-ground periods. The dataset generated by this effort could be used to calibrate and verify agricultural rainfall-runoff models, identify periods and conditions for which runoff is most likely, and help producers, agency groups, and other managers to implement effective management strategies that could reduce field-edge runoff and transportation of associated sediment, nutrients, and other agrichemicals to downstream water bodies.

\section{Annual Precipitation and Runoff}

Annual precipitation amounts ranged from a low of 22.8 in. at farm NE1 in 2007 and at farm NE2 in 2005 to a high of 44.0 in. at Pioneer Farm in 2008 (fig. 10). The 30-year mean annual precipitation (1971-2000), averaged for nearby weather stations listed in table 9, was about 34 in. Of the 26 monitored farm years of data for 2003-8, there were 3 years in which annual precipitation was $\leq 20$ percent greater than the 30-year mean, 6 years in which annual precipitation was $\leq 20$ percent less than the 30 -year mean, and 17 years in which annual precipitation was within 20 percent of the 30 -year mean. Runoff and constituent yields resulting from these variations in annual precipitation could be representative of typical ranges of runoff from fields in similar landscapes with similar management practices and climates.

Despite year-to-year variability, a majority of the monitored farms received precipitation amounts within 20 percent of the 30-year mean during any given year, and the mean annual precipitation for all 26 farm years was 32.8 in., about 3 percent lower than the 30 -year mean. Consequently, runoff amounts and constituent yields averaged for the entire study period could be representative of typical long-term runoff from fields in similar landscapes with similar management practices and climates.

Annual precipitation during water year 2005 was the lowest among any year: at all monitored farms but one, precipitation amounts were less than the 30 -year mean by 20 percent or more. Annual precipitation was highest during water year 2008: at each of the monitored farms in the southwest, precipitation amounts were greater than the 30 -year mean by at least 20 percent; at two farms (SE1 and NE2), precipitation amounts were between 5 and 15 percent greater than the 30-year mean; and at farm NE1, the precipitation amount was less than the 30-year mean. Water year 2007 was a year of widely contrasting precipitation amounts among farms. Although the two farms in the northeast received annual precipitation amounts much less than the 30-year mean, the southeast farm (SE1) received precipitation amounts much higher than the 30-year mean.

Annual runoff for all 26 farm years averaged $2.55 \mathrm{in} /$ acre -8 percent of annual precipitation (fig. 11). Runoff amounts ranged from 0.10 in/acre at farm SW1 in water year 2006 to $6.17 \mathrm{in} /$ acre at farm SE1 in water year 2008. Runoff as a percentage of precipitation was less than 1 percent at all three southwest farms in 2006, the lowest of any farm and year. The highest percentages were noted at farm NE1 in 2004, NE2 in 2005, and farms SE1 and NE2 in 2008, when nearly 15 percent or more of precipitation was measured as runoff. Percentages were generally greater in the northeast section than in the southwest. The more clayey soils at the farms in the northeast section may have reduced infiltration and increased the amount of surface runoff per unit precipitation. 

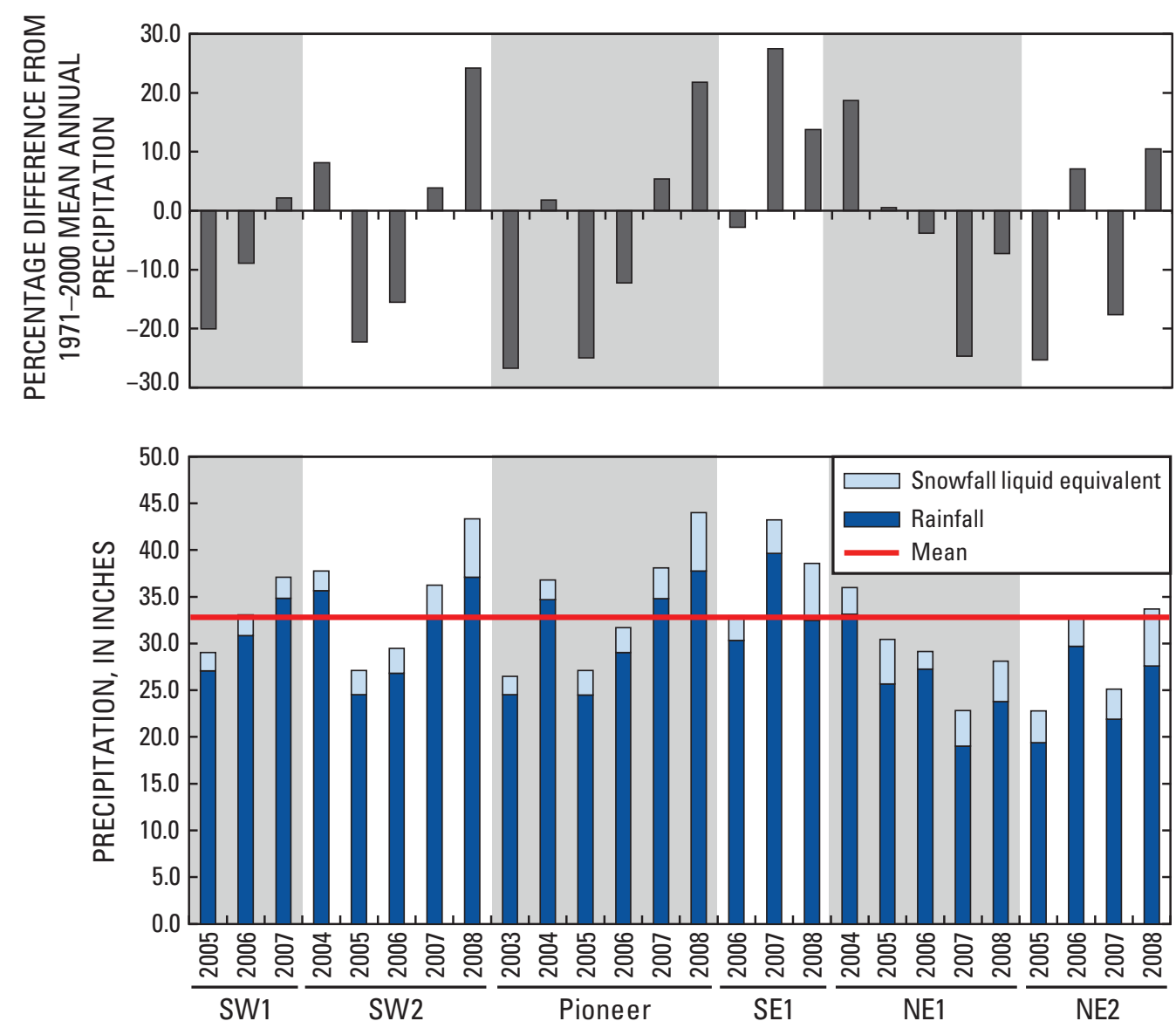

Figure 10. Mean annual precipitation and percentage difference from 1971-2000 mean annual precipitation at nearby NOAA weather stations, Discovery Farms and Pioneer Farm, water years 2003-8. Snowfall liquid equivalent was estimated by using snowfall depth from nearby NOAA weather stations and a ratio of 14 inches of snowfall to 1 inch of liquid equivalent (Baxter and others, 2005).
Figure 11. Mean annual runoff and runoff as percentage of annual precipitation, Discovery Farms and Pioneer Farm, water years 2003-8.
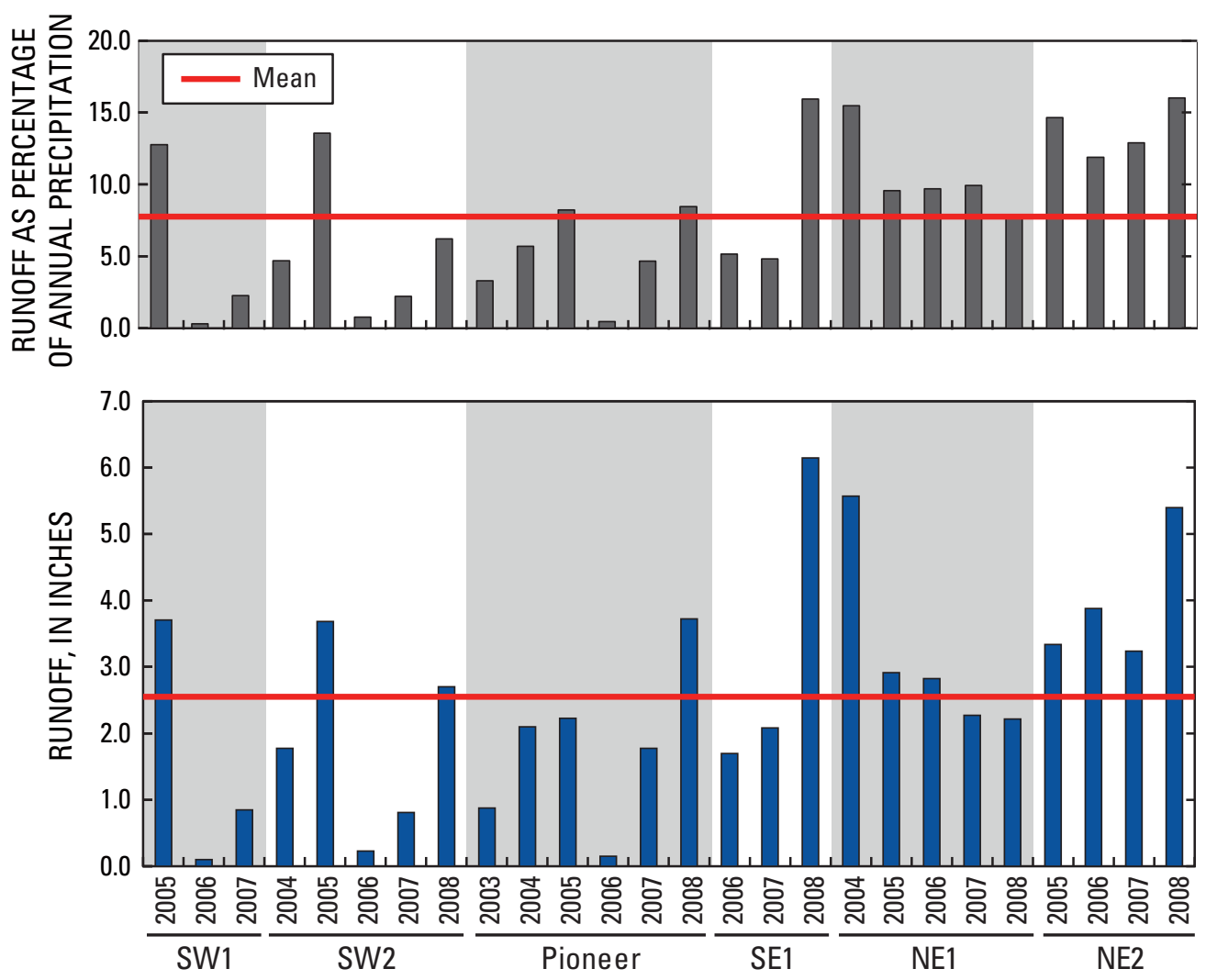
The highest mean annual runoff was in water year 2008 (4.04 in/acre), followed by water year 2005 (3.17 in/acre) (table 10). The lowest mean runoff ( 0.88 in/acre) was in water year 2003, although Pioneer Farm was the only farm with monitoring stations at the time. The next-lowest mean runoff was in water year 2006 (1.48 in/acre).

Annual runoff was not necessarily related to annual precipitation amounts. This is especially apparent for water year 2005, when measured precipitation among the farms was the lowest of any year. Despite this low annual precipitation amount, mean annual runoff was nearly equal to that in water year 2008 - a year in which precipitation was greater than the long-term average for almost all farms. Rather than simply the annual amount of precipitation received, a combination of factors, including rainfall intensity and soil condition (high antecedent soil moisture compared to low, frozen compared to unfrozen), were likely important factors that determined the amount of annual runoff yielded from field edges during the study period. The data were subsequently analyzed on smaller time scales to investigate these factors.

\section{Monthly Precipitation and Runoff}

During frozen-ground periods, mean monthly runoff was highest in February and March (0.41 and 0.87 in., respectively), constituting 50 percent of the overall mean annual runoff even though these months accounted for only 11 percent of the annual precipitation (table 11). Typically, the ground was frozen and snow-covered during these months, and most runoff was the result of snowmelt and (or) rain on snow. Rain falling on frozen ground with no snow occasionally produced runoff, but the contribution to runoff totals from these events was typically much less than that from either snowmelt or rain on snow. Runoff during frozen-ground periods was significantly longer in duration and greater in volume than runoff during unfrozen-ground periods $(\mathrm{p}<0.05)$, and peak discharges were significantly lower.
During unfrozen-ground periods, the highest mean monthly runoff was in May and June (0.32 and 0.48 in., respectively), which constituted 31 percent of the overall mean annual runoff. Runoff in May and June was typically the result of high-intensity and (or) repetitive rainfall events with short recurrence intervals (and thus high antecedent soil moisture). Crop cover was usually minimal during these months, especially for fields planted in either corn or soybeans, and soils tended to be compacted from soil preparation (tillage and finishing, in some cases) and planting.

Runoff was zero during many months throughout the study period, but no monthly mean runoff (of all 26 farm years) was zero. The lowest mean monthly runoff was for September through December, when it was 0.10 in. or less. From a calendar-year perspective, 90 percent of annual runoff occurred between January 1 and June 30 .

March, in addition to having the highest mean monthly runoff, was the only month in which runoff was generated at each farm and in each year. The next-highest mean monthly runoff frequencies were for January, February, and April, each with measureable runoff in about 50 percent of the farm years. Runoff amounts during these months were markedly different: relatively low in January and April at about 0.10 in., but 4 times that, about 0.41 in., in February. Runoff frequencies were lowest in August, September, October, and November, with runoff observed for about 20 percent of the farm years.

Although runoff as a percentage of precipitation averaged 8 percent during the study period, the highest percentages were observed in February and March, when 28 and 39 percent of precipitation was measured as runoff, respectively. These percentages are somewhat exaggerated because of a lag effect (snow falling in December may contribute to runoff in March, for example); nonetheless, the higher percentages in February and March demonstrate that runoff from precipitation inputs during these months was more likely. Studies have shown that frozen soils can limit infiltration and lead to increased surface runoff (Zuzel and Pikul, 1987; Kane and Chacho, 1990; Daniel and Staricka, 2000; Bayard and others, 2004). This reduced infiltration, along with the typical availability of water held in the form of snow and (or) ice, often resulted in prolonged periods of snowmelt runoff, especially in February and March when air temperatures started to increase.

Table 10. Annual runoff, in inches, and percentage of total runoff distributed between frozen- and unfrozen-ground periods, Discovery Farms and Pioneer Farm, water years 2003-8.

$[\%$, percent $]$

\begin{tabular}{|c|c|c|c|c|c|c|c|}
\hline Number of farm years included & (1) & (3) & (5) & (6) & (6) & (5) & Mean of all 26 \\
\hline Water year & 2003 & 2004 & 2005 & 2006 & 2007 & 2008 & farm years \\
\hline $\begin{array}{l}\text { Frozen-ground runoff } \\
\text { (Percentage of annual total) }\end{array}$ & $\begin{array}{r}0.27 \\
(30 \%)\end{array}$ & $\begin{array}{r}1.58 \\
(50 \%)\end{array}$ & $\begin{array}{r}3.12 \\
(98 \%)\end{array}$ & $\begin{array}{r}0.64 \\
(43 \%)\end{array}$ & $\begin{array}{r}1.13 \\
(62 \%)\end{array}$ & $\begin{array}{r}0.94 \\
(23 \%)\end{array}$ & $\begin{array}{r}1.38 \\
(54 \%)\end{array}$ \\
\hline $\begin{array}{l}\text { Unfrozen-ground runoff } \\
\text { (Percentage of annual total) }\end{array}$ & $\begin{array}{r}.61 \\
(70 \%)\end{array}$ & $\begin{array}{r}1.57 \\
(50 \%)\end{array}$ & $\begin{array}{r}.05 \\
(2 \%)\end{array}$ & $\begin{array}{r}.84 \\
(57 \%)\end{array}$ & $\begin{array}{r}.71 \\
(38 \%)\end{array}$ & $\begin{array}{r}3.09 \\
(77 \%)\end{array}$ & $\begin{array}{r}1.17 \\
(46 \%)\end{array}$ \\
\hline Total & 0.88 & 3.15 & 3.17 & 1.48 & 1.84 & 4.04 & 2.55 \\
\hline
\end{tabular}


Table 11. Selected summary statistics for runoff and precipitation at Discovery Farms and Pioneer Farm, $2003-8$.

$[\%$, percent; <, less than; units are in inches unless otherwise indicated; runoff, in inches, was calculated by dividing runoff volume by the basin area; monthly runoff frequency was determined by summing the number of months with non-zero runoff and then dividing by 26]

\begin{tabular}{lccccc}
\hline & $\begin{array}{c}\text { Mean monthly } \\
\text { runoff } \\
\text { (inches) }\end{array}$ & $\begin{array}{c}\text { Mean monthly runoff } \\
\text { as a percentage } \\
\text { of annual runoff }\end{array}$ & $\begin{array}{c}\text { Runoff } \\
\text { frequency } \\
\text { (percent) }\end{array}$ & $\begin{array}{c}\text { Mean monthly } \\
\text { precipitation } \\
\text { (inches) }\end{array}$ & $\begin{array}{c}\text { Mean monthly runoff } \\
\text { as a percentage } \\
\text { of precipitation }\end{array}$ \\
\hline October & 0.07 & $3 \%$ & $23 \%$ & 2.32 & $3 \%$ \\
November & .02 & $<1 \%$ & $15 \%$ & 2.22 & $1 \%$ \\
December & .04 & $1 \%$ & $35 \%$ & 1.73 & $2 \%$ \\
January & .10 & $4 \%$ & $50 \%$ & 1.68 & $6 \%$ \\
February & .41 & $16 \%$ & $58 \%$ & 1.48 & $28 \%$ \\
March & .87 & $34 \%$ & $100 \%$ & 2.22 & $39 \%$ \\
April & .11 & $4 \%$ & $54 \%$ & 3.42 & $3 \%$ \\
May & .32 & $12 \%$ & $38 \%$ & 3.70 & $9 \%$ \\
June & .48 & $19 \%$ & $42 \%$ & 3.83 & $13 \%$ \\
July & .07 & $3 \%$ & $42 \%$ & 3.90 & $2 \%$ \\
August & .07 & $3 \%$ & $19 \%$ & 3.55 & $2 \%$ \\
September & $<.01$ & $<1 \%$ & $19 \%$ & 2.76 & $<1 \%$ \\
Annual mean & 2.55 & & & 32.80 & $8 \%$ \\
\hline
\end{tabular}

In most months, notably April and July through December, runoff as a percentage of precipitation was less than 5 percent. In May and June, the percentages were 9 and 13 percent, respectively, and runoff amounts in these months were higher than in other months when the ground was not frozen.

An important factor in determining the amount and likelihood of runoff during these unfrozen-ground periods was antecedent soil moisture, a measure of the amount of soil-pore space filled with water. Figure 12 shows an example of the distribution of runoff data during a 5-year period at Discovery Farm NE1, demonstrating that a large percentage of the overall runoff volume was generated when antecedent soil moisture was considered to be high (35 percent or greater). Using a subset of the precipitation, soil moisture, and runoff data during unfrozen-ground periods at Discovery Farm SW2, Radatz (2009) determined that antecedent soil moisture and the 30-minute maximum precipitation intensity were key factors in predicting runoff.

Ranges in mean monthly runoff were varied among the 26 farm years, especially for February, March, May, and June (fig. 13). Even though runoff as a percentage of precipitation was relatively low for May and June compared to those percentages for February and March, the largest mean monthly runoff amounts in May and June were of similar magnitude to or greater than those in February and March. A maximum mean monthly runoff of nearly $2.60 \mathrm{in}$. was observed in both February and March, whereas a maximum of 2.80 in. was observed in May and a maximum of 5.05 in. (the highest of any month) was observed in June. Maximum mean monthly runoff was much lower during September (0.05 in.) and
November (0.18 in.). For the remainder of the months, maximum mean monthly runoff was between the extremes at about 0.50 to $1.00 \mathrm{in}$. With the exception of March, the minimum mean monthly runoff was zero for all other months.

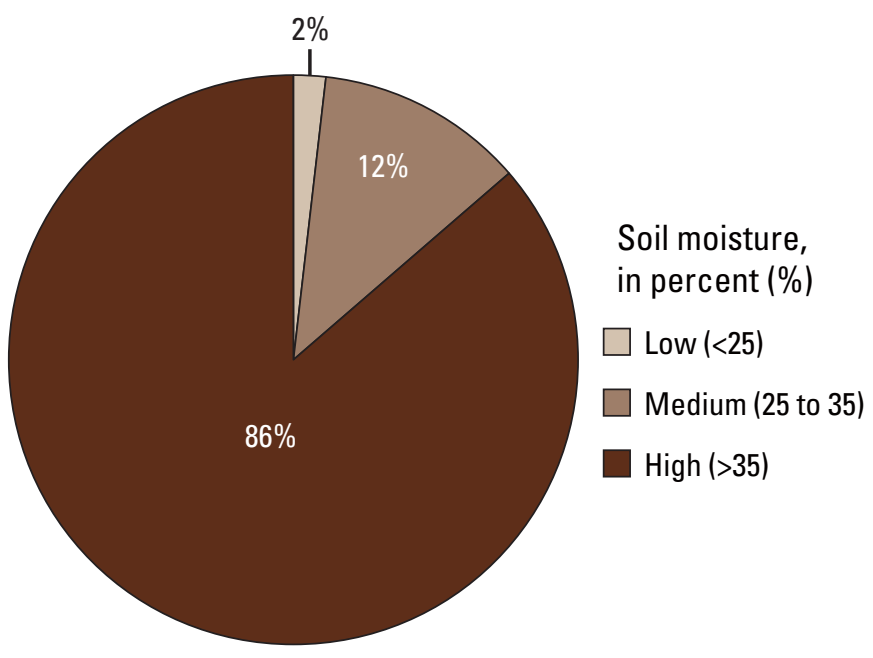

Figure 12. Percentage of total runoff during low, medium, and high antecedent soil-moisture conditions for unfrozen-ground periods, Discovery Farm NE1, water years 2003-8. Soil-moisture percentage is volumetric, calculated by dividing the volume of water in the soil by the total volume of soil and multiplying the result by 100 . The maximum in most saturated soils is about 50 percent (Dunne and Leopold, 1978). 


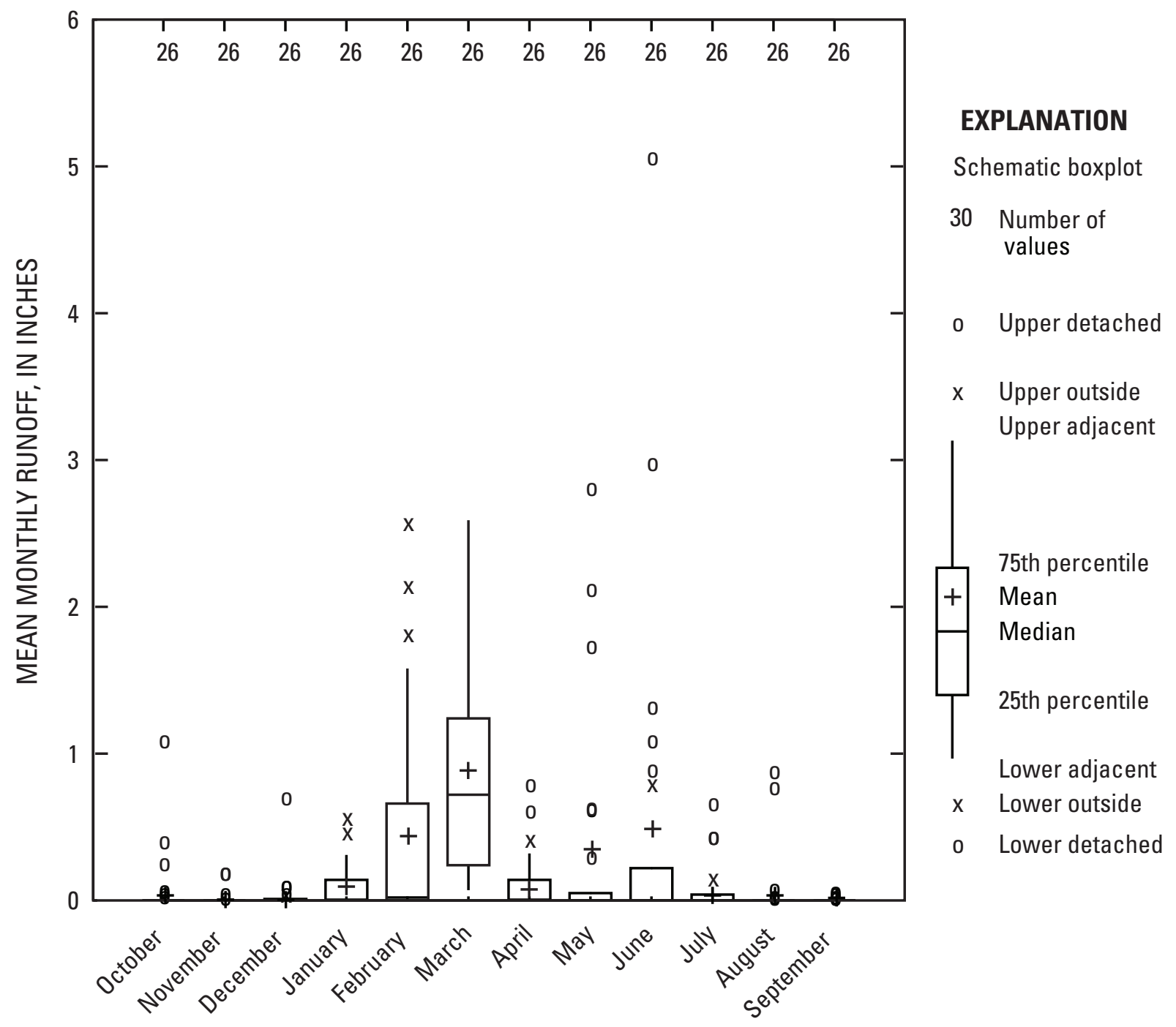

Figure 13. Distribution of mean monthly runoff for all 26 farm years of data, Discovery Farms and Pioneer Farm, water years 2003-8.

\section{Seasonal Runoff Distribution}

Analysis of the monthly precipitation and runoff data for the entire monitoring period showed that late winter (February and March) and late spring/early summer (May and June) were seasons in which (1) mean monthly runoff volume was the highest, (2) percentage of annual runoff was the highest, and (3) runoff as a percentage of precipitation was the highest. Although these seasons shared some commonality with regard to these runoff characteristics, the conditions in which runoff occurred and the resulting potential effects on water quality were often different. Understanding these differences and their potential to influence runoff volume and water quality could bring a better understanding of the impacts of agriculture in Wisconsin on water quality.

One difference between winter and spring/early summer was the soil conditions corresponding to runoff. For the study period (water years 2003 to 2008), soils were typically frozen from early December to late March; therefore, nearly all runoff during these months was when soils were frozen. When soils were frozen, particles were stuck together by frozen pore water, resulting in reduced infiltration rates and increased runoff volumes. In addition, soil particles that were frozen together were less likely to become dislodged in runoff. It is therefore likely that constituent concentrations and yields in runoff during frozen-ground periods were different from those when the ground was thawed, especially for sediment and sediment-associated constituents. A second difference between winter and spring/early summer was in field activities. During the study period, winter field activities on the monitored livestock farms were limited primarily to manure-nutrient applications. Manure storage was limited, and the potential to cause soil compaction while spreading manure is reduced when soils are frozen. Other field activities such as planting, soil preparation, chemical fertilization, and so forth, were pursued when soils were thawed. Field activities have been shown to affect 
water quality; for example, studies have shown that manure applied to frozen and (or) snow-covered soils can result in substantial nutrient concentrations and yields in runoff (Srinivasan and others, 2006, Komiskey and others, 2011). Because of the differences in seasonal field activities, an understanding of these activities in relation to the seasonal timing of runoff would likely be important.

A third difference between winter and spring/early summer was the state of vegetative growth. During winter, crops were dormant, and little or no crop canopy existed. In addition, certain conservation-management practices depend on vegetation to slow and (or) filter runoff water; if a substantial proportion of runoff occurs when vegetation is not growing, these practices will likely be less effective than expected.

A final difference between winter and spring/early summer was precipitation and runoff characteristics. Runoff during frozen-ground periods was caused primarily by snowmelt and (or) rain on snow, and it was generally longer in duration and with lower peak discharges than runoff during unfrozenground periods. Runoff during unfrozen-ground periods was caused by rainfall only. The energy exerted by raindrops falling upon soils (and potentially dislodging them) is realized more so during these periods than during frozen-ground periods.

\section{Comparison of Frozen- and Unfrozen-Ground Runoff}

Owing to differences in soil condition, field activities, vegetative growth, and precipitation and runoff characteristics between winter and spring/early summer, the distribution of runoff between these seasons was examined. To simplify potentially complex matrices of differing seasonal conditions discussed above, data for the remainder of the report were organized to compare and contrast frozen- and unfrozenground periods in terms of runoff volume and for constituent concentrations and yields.
For all 26 farm years, annual runoff averaged $1.38 \mathrm{in}$. (54 percent of annual runoff average) during frozen-ground periods and 1.17 in. (46 percent of annual runoff average) during unfrozen-ground periods (fig. 14). Despite this relatively similar distribution averaged for the duration of the monitoring period, the percentage of runoff contributed during frozen- and unfrozen-ground periods was highly variable from year to year. In water year 2005, nearly all runoff was from frozen ground. In contrast, 70 percent or more of annual runoff occurred during unfrozen-ground periods in water years 2003 and 2008.

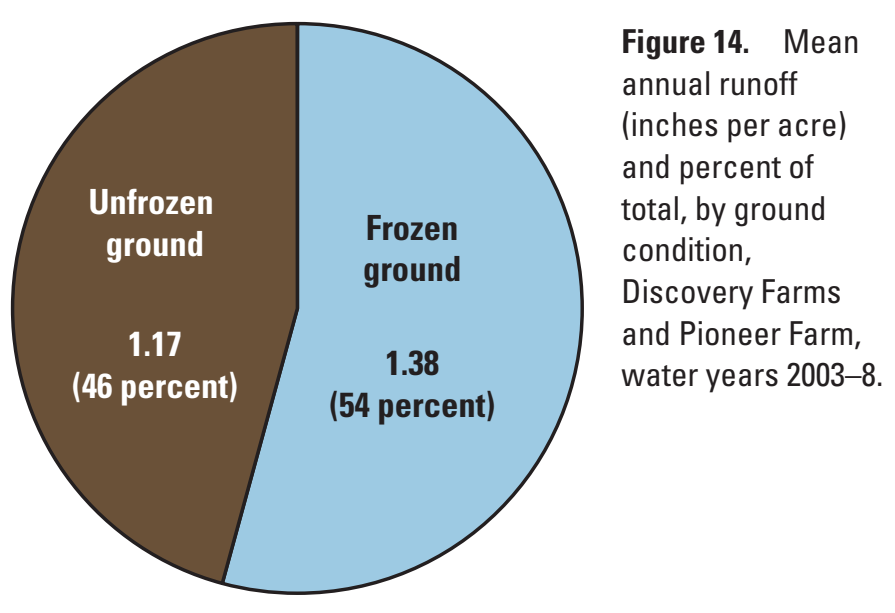

Distributions of runoff between frozen- and unfrozenground periods were also highly variable between the farms (fig. 15). For some farms and years, such as at farm SE1 in water years 2007 and 2008, less than 10 percent of runoff was from frozen ground. For 9 of the 26 farm years, however, nearly 100 percent of runoff was from frozen ground. Overall, 50 percent or more of annual runoff occurred during the frozen-ground period for 16 of 26 farm years of data. 


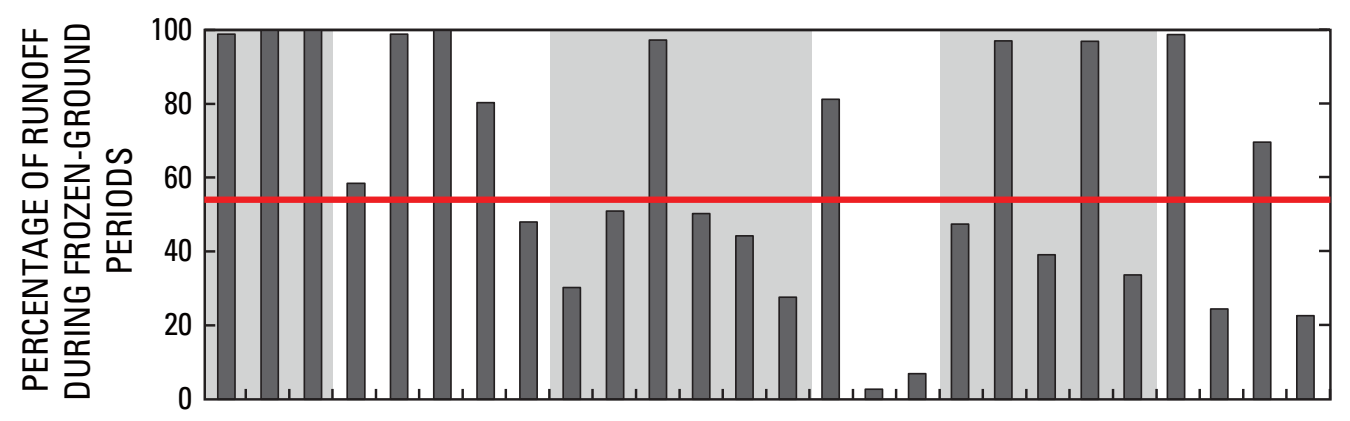

Figure 15. Mean annual runoff and percentage of total runoff during frozen-ground periods, Discovery Farms and Pioneer Farm, water years 2003-8.

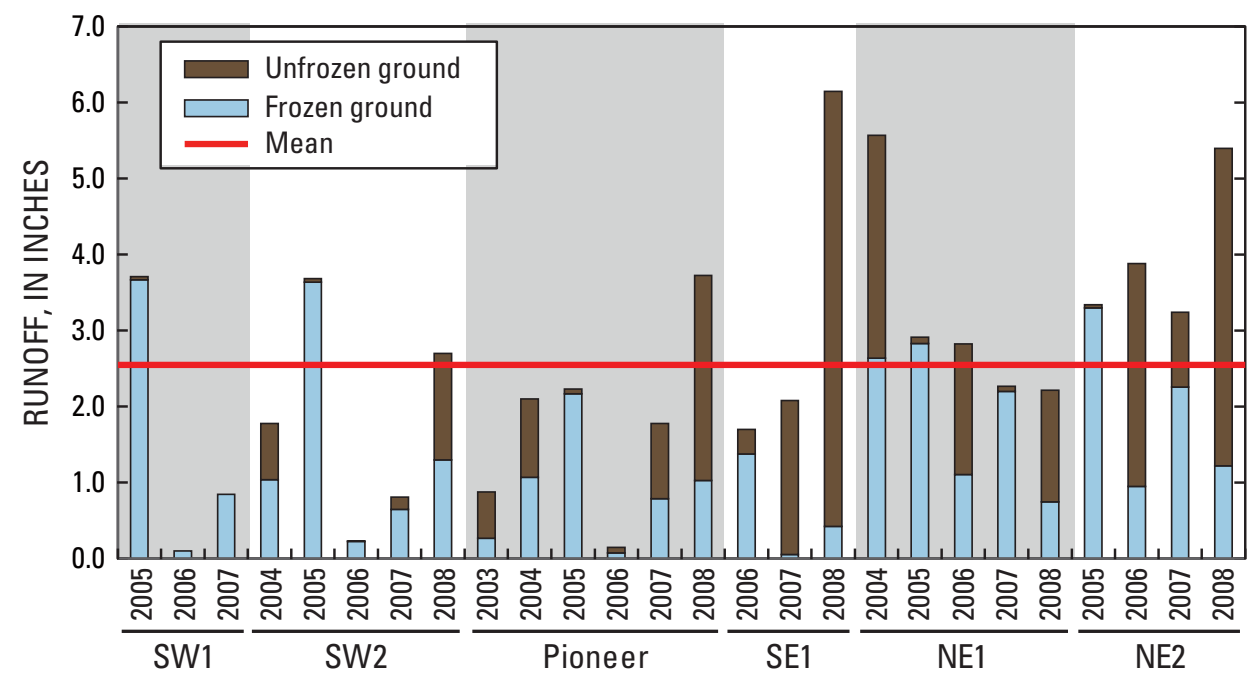

\section{Water-Quality Characteristics}

The water-quality component of this study was designed to examine the magnitude, distribution, and selected factors affecting concentrations and yields of sediment, nutrients, and other constituents commonly found in runoff from agricultural fields. Concentrations and yields of suspended sediment, phosphorus (total, particulate, and dissolved reactive), and nitrogen (total, nitrate plus nitrite, organic, and ammonium) are described in the text and are summarized in the appendixes. With consideration to report length, data for total Kjeldahl nitrogen, chloride, total dissolved solids, total solids, total suspended solids, total volatile suspended solids, total Kjeldahl nitrogen-dissolved, and total dissolved phosphorus are not discussed in the text, but concentration and yield data are summarized in the appendixes.

\section{Suspended Sediment}

Soil is an important resource for agricultural production and sustainability. Soil properties affect crop production, compaction, drainage, and runoff. Excessive nonpoint-source yields (loss per unit area) of soil (suspended sediment) have been well documented as a water pollutant (Waters, 1995; U.S. Environmental Protection Agency, 1998). Sediment in runoff from agricultural fields that enters surface-water bodies can harm biotic habitats by reducing water clarity, interfering with instream water-treatment properties, and degrading spawning habitat (Robertson and others, 2006). In addition, sediment particles typically have high affinity for certain nutrients and agrichemicals that can enter receiving waters while attached to transported sediments. The impacts of sediment contributions and associated nutrients and agrichemicals can be observed for years in natural stream systems, owing to their presence in "legacy sediments" (Fitzpatrick and others, 2007).

\section{Suspended-Sediment Concentrations}

Median event mean concentrations of suspended sediment in runoff during unfrozen-ground periods were significantly higher $(\mathrm{p}<0.05)$ than those during frozen-ground periods (fig. 16). Median event mean concentrations of suspended sediment in runoff ranged from 153 to more than $3,100 \mathrm{mg} / \mathrm{L}$ among farms during unfrozen-ground periods and from 24 to $32 \mathrm{mg} / \mathrm{L}$ among farms during frozen-ground periods. The median suspended-sediment concentrations among farms during the frozen-ground period were similar despite differences in management systems, field conditions, slopes, soil types, runoff amounts, and other factors. This finding implies that the influence any of these factors had on sediment concentrations (and likely other sediment-bound constituents) was minimized when runoff occurred during frozen-ground periods. The most likely reason was that soil particles were frozen together and less likely to become transported in runoff, regardless of differences among fields. 


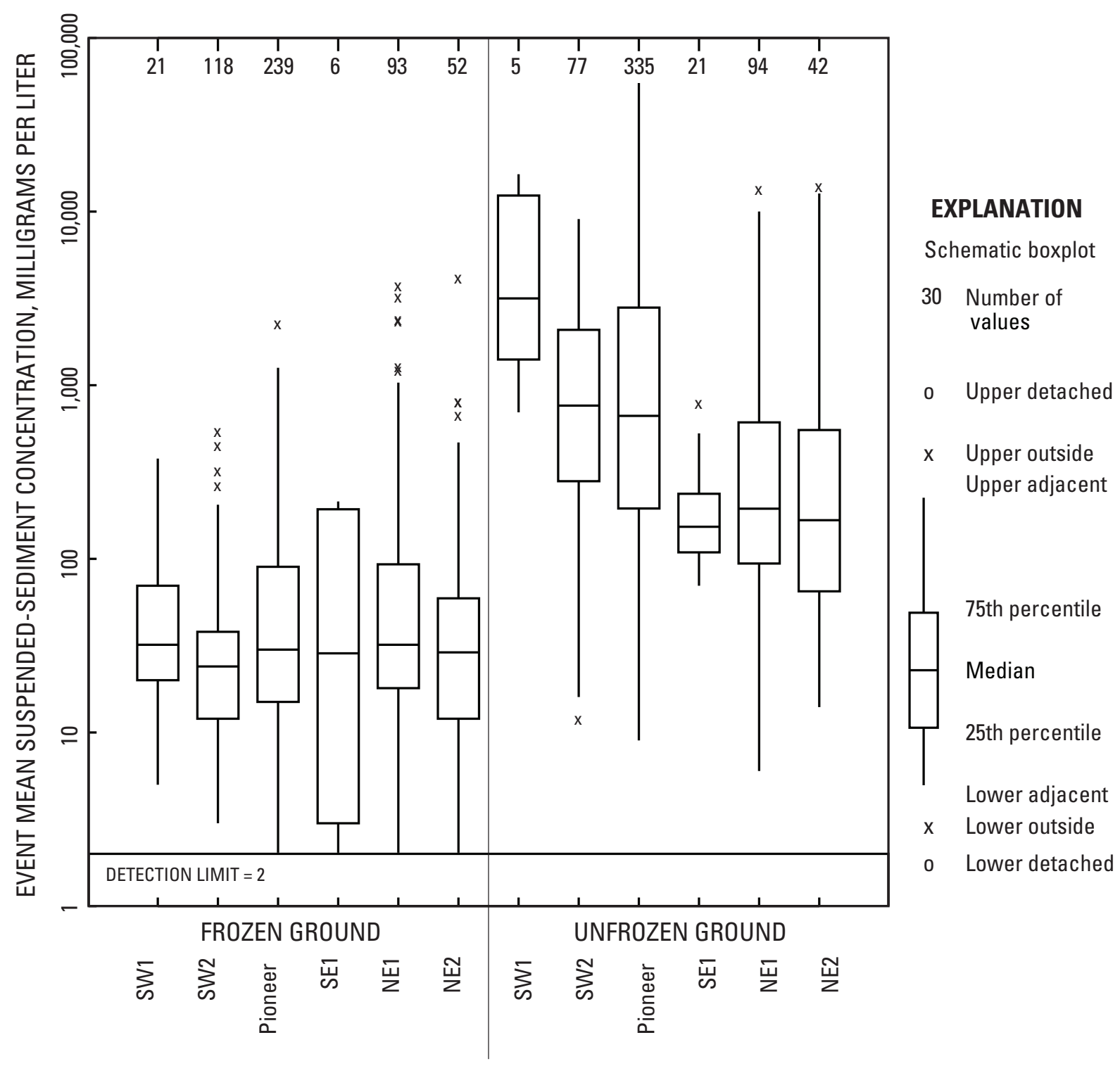

Figure 16. Distribution of event mean concentrations of suspended sediment in runoff during frozen- and unfrozen-ground periods, Discovery Farms and Pioneer Farm, water years 2003-8.

Although median event mean suspended-sediment concentrations were lower in runoff during frozen-ground periods, event mean concentrations for individual events occasionally exceeded $1,000 \mathrm{mg} / \mathrm{L}$. These higher concentrations corresponded to March and April runoff events when soils were starting to thaw, and they were possibly the result of runoff when the ground was frozen at depth but not at the soil surface. Thawing of the soil surface would have allowed sediment to be more easily detached and transported in overland runoff. Another possibility for these higher concentrations in runoff during frozen-ground periods was that soils were thawed in the field but not at the meteorological station.

\section{Suspended-Sediment Yields}

Mean annual suspended-sediment yields ranged from 3 to nearly 5,000 lb/acre, with an overall mean yield of $667 \mathrm{lb} /$ acre (fig. 17). For most farms and for most years, mean annual suspended-sediment yields were less than the overall mean yield; however, yields at Pioneer Farm in 2004 and 2008, farm NE1 in 2006 and 2008, and farm NE2 in 2006 exceeded the overall mean yield. At each of these farms and for each of these years, high-intensity and (or) repetitive rainfall events with short recurrence intervals (thus creating high antecedent soil moisture) occurred in May and (or) June, causing runoff from recently tilled corn fields. Suspended sediment in runoff from these events typically contributed a high proportion of the annual suspended-sediment yield for each of those years. 


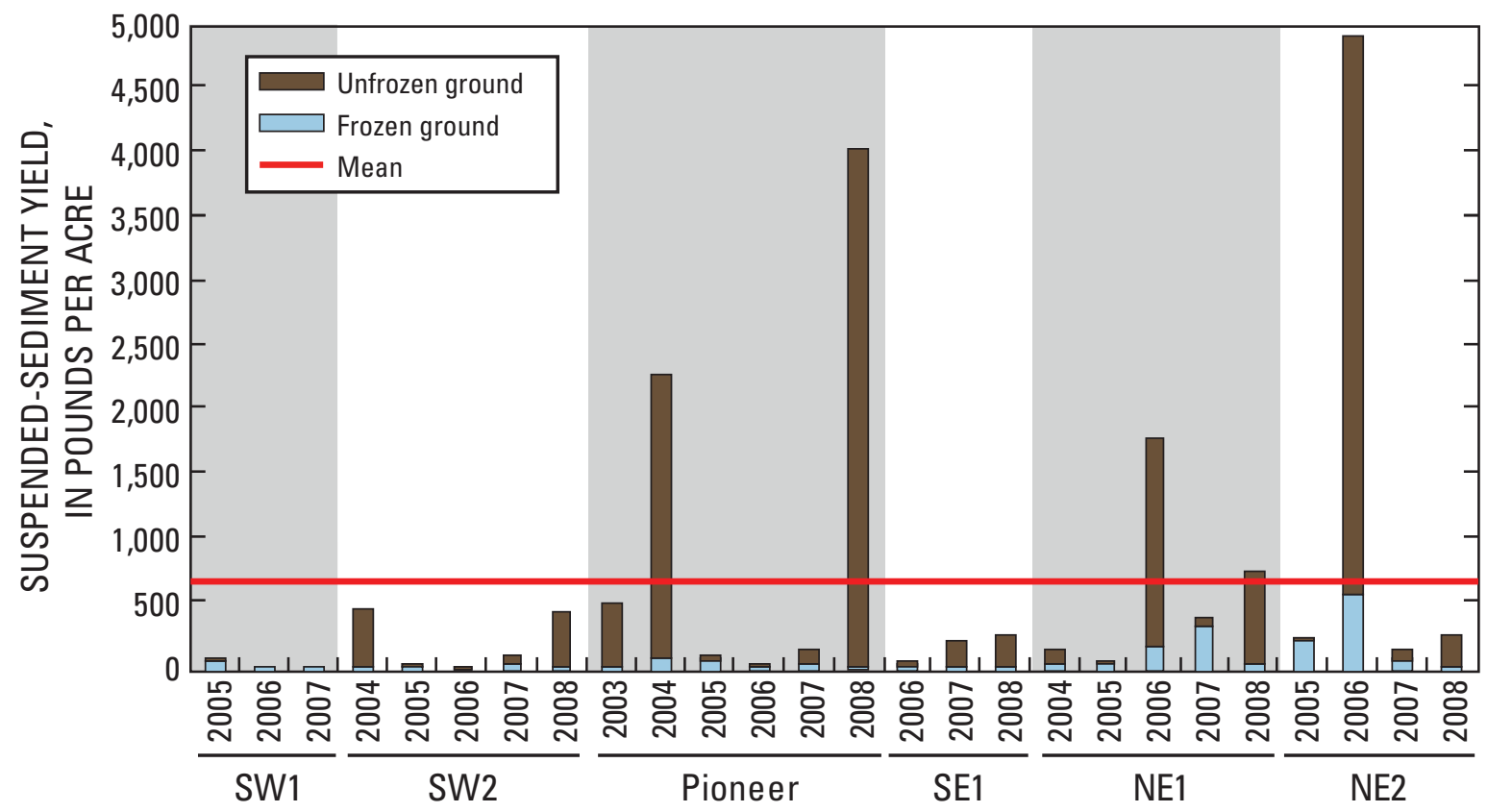

Figure 17. Mean annual suspended-sediment yield, Discovery Farms and Pioneer Farm, water years 2003-8.

Like concentrations, yields of suspended sediment were greater in runoff during unfrozen-ground periods than during frozen-ground periods. In years consisting of mostly frozenground runoff (farm SW1 in 2005, farm SW2 in 2005, Pioneer Farm in 2005, farm SE1 in 2006, farm NE1 in 2005 and 2007, and farm NE2 in 2005, for example), annual suspendedsediment yields were consistently less than the overall mean yield, regardless of differences in farm-management systems, slopes, soil types, runoff amount, and other factors. Years with the highest suspended-sediment yields (Pioneer Farm in 2004 and 2008, farm NE1 in 2006 and 2008, and farm NE2 in 2006) always corresponded with years in which a significant proportion of the annual runoff ( 50 percent or more) occurred during unfrozen-ground periods.

Annual runoff amounts did not necessarily correspond to annual suspended-sediment yields. Farms and years with the three highest runoff amounts (farms SE1 and NE2 in 2008 and farm NE1 in 2004) all had annual sediment yields much less than the overall mean yield. In 2004, the annual runoff amount at Pioneer Farm was relatively low, yet the annual sediment yield was one of the highest. Ground conditions and the timing of runoff with respect to ground conditions were more related to suspended-sediment yields than were annual runoff amounts.

The importance of ground conditions (most notably frozen ground versus unfrozen ground) during runoff and the relation of those conditions to suspended-sediment yields are further demonstrated in figure 18. Despite relatively high mean monthly runoff in February and March, suspendedsediment yields for those months were disproportionally lower than those for May and June with respect to runoff. In addition, despite the fact that the overall annual runoff volume was nearly equally distributed between frozen- and unfrozenground periods, 10 percent $(67 \mathrm{lb} / \mathrm{acre}$ ) of annual suspendedsediment yields occurred during frozen-ground periods and the remaining 90 percent (600 lb/acre) occurred during unfrozenground periods. May and June alone contributed more than 80 percent of the annual suspended-sediment yield. 


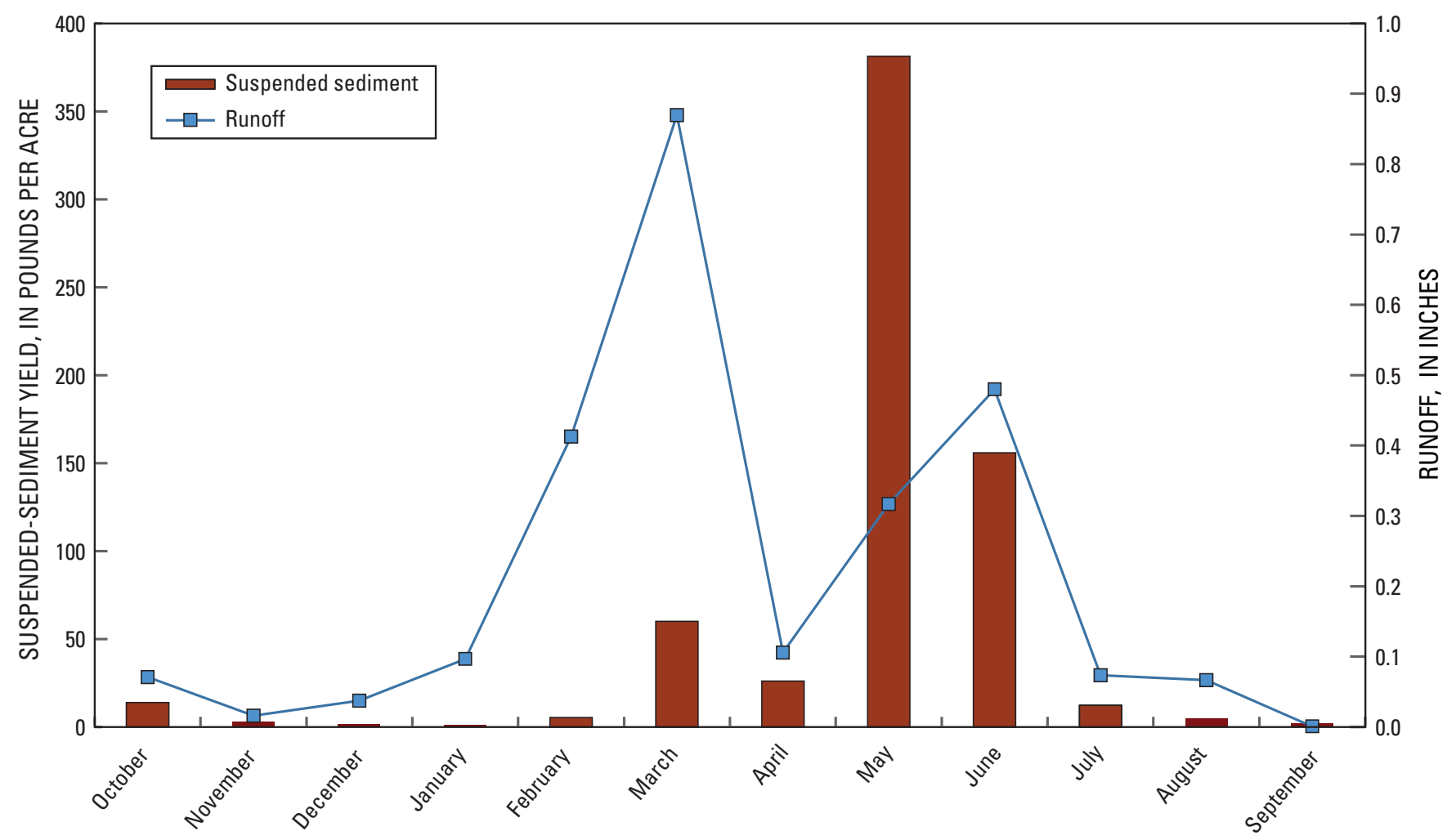

Figure 18. Mean monthly suspended-sediment yield and runoff, Discovery Farms and Pioneer Farm, water years 2003-8.

\section{Phosphorus}

Phosphorus is a naturally occurring element that is also an important nutrient for plants and animals. Common sources of phosphorus in agricultural landscapes include soil, plants, livestock feed, fertilizer, manure, and precipitation (Sturgul and Bundy, 2002). Although an essential nutrient, excessive phosphorus in water bodies can cause water-quality deterioration (Daniel and others, 1998; Owens and Shipitalo, 2006). Overabundance of phosphorus accelerates the growth of algae and other aquatic plants, which can result in water-quality problems, such as low dissolved-oxygen levels that can stress or kill fish, reduce recreational uses, and cause unpleasant odors. Phosphorus delivered from the U.S. Midwest in the Mississippi River was recently identified as a major contributor to hypoxia in the Gulf of Mexico (Sylvan and others, 2006).

Phosphorus is transported in runoff in both particulate and dissolved forms, the sum of which is termed "total phosphorus." Particulate phosphorus (also commonly referred to as "sediment phosphorus") is commonly soil bound, including that portion bound to particles greater than 0.45 $\mu \mathrm{m}$ in diameter; however, particulate phosphorus can also be found when large, organic particulates associated with manure or crop residue become entrained in runoff water. Phosphorus has a high affinity to soil particles and is resistant to leaching in most soils. As a consequence, most phosphorus is stored in the upper layers of the soil profile. The highest phosphorus concentrations are usually found in the top layers of soil (especially in no-till production systems), so the soil phosphorus level in agricultural fields is a concern because of the potential for erosion and phosphorus transport (Sharpley and others, 1999; Sturgul and Bundy, 2002).

Dissolved phosphorus (or soluble phosphorus) includes that bound to particles less than $0.45 \mu \mathrm{m}$ in diameter and also that dissolved in solution in various forms. Dissolved phosphorus in aquatic ecosystems is especially important because it is more readily available for uptake by algae and other aquatic plants than particulate phosphorus. Particulate phosphorus can be a long-term concern because phosphorus can be released into bioavailable forms over time (Haggard and others, 2007). 


\section{Total-Phosphorus Concentrations}

Event mean concentrations of total phosphorus in runoff during unfrozen-ground periods were significantly higher $(p<0.05)$ than those during frozen-ground periods. Median event mean concentrations of total phosphorus in runoff ranged from 0.60 to $2.68 \mathrm{mg} / \mathrm{L}$ among farms during frozenground periods and from 1.13 to $4.21 \mathrm{mg} / \mathrm{L}$ during unfrozenground periods (fig. 19).

Event mean concentrations of total phosphorus for individual runoff events ranged from $<0.01$ to $42.60 \mathrm{mg} / \mathrm{L}$ during frozen-ground periods and from 0.18 to $35.33 \mathrm{mg} / \mathrm{L}$ during unfrozen-ground periods. Although the highest concentrations between frozen- and unfrozen-ground periods were of relatively similar magnitude, the conditions in which they occurred were different. During frozen-ground periods, the highest total-phosphorus concentrations were often recorded when manure was applied to the monitored fields shortly before runoff (days or weeks). During unfrozen-ground periods, the highest total-phosphorus concentrations were often recorded when suspended-sediment concentrations also were the highest.

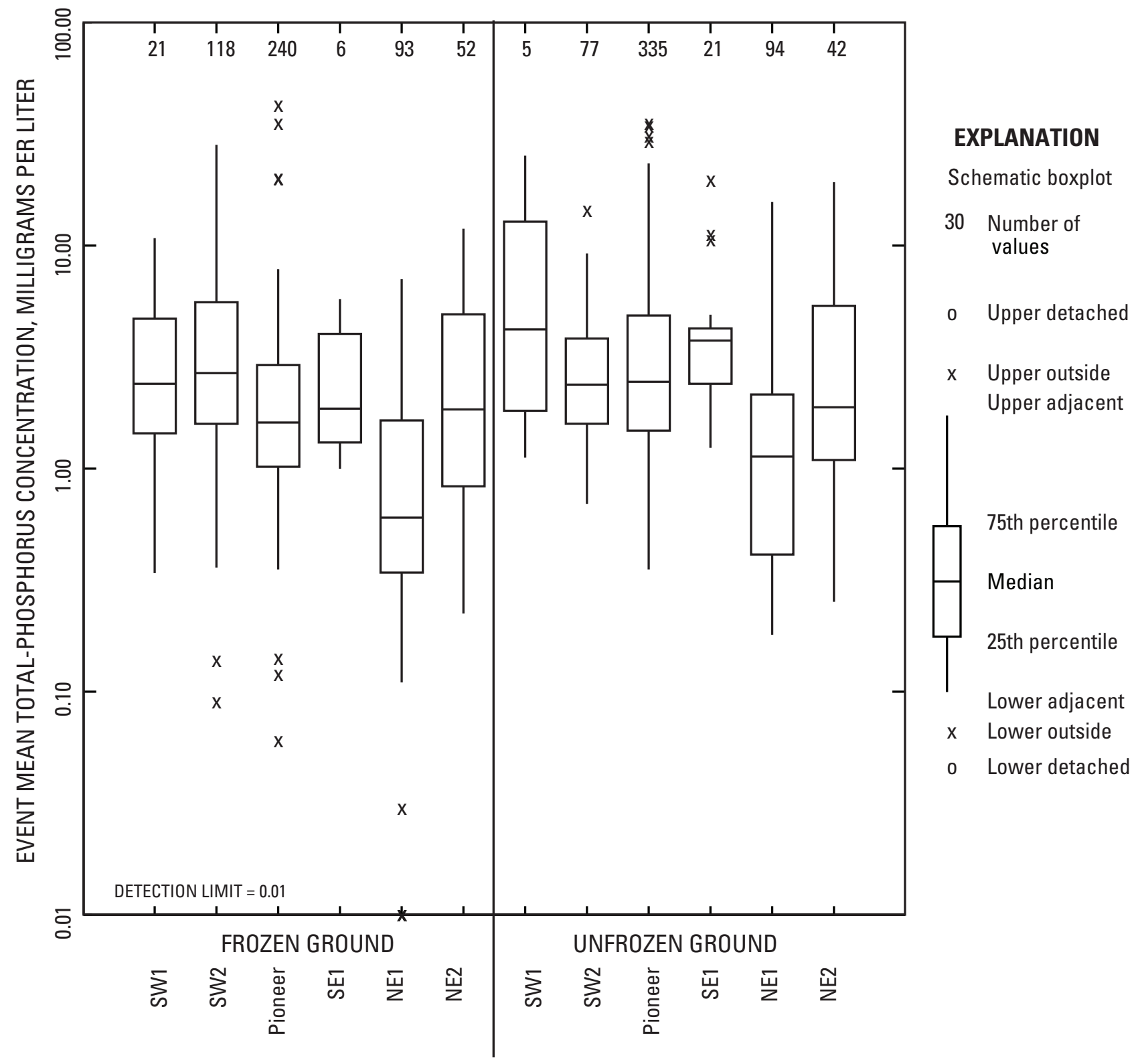

Figure 19. Distribution of event mean concentrations of total phosphorus in runoff during frozen- and unfrozen-ground periods, Discovery Farms and Pioneer Farm, water years 2003-8. 


\section{Total-Phosphorus Yields}

Mean annual total-phosphorus yields ranged from 0.03 to $7.0 \mathrm{lb} / \mathrm{acre}$, with an overall mean yield of about $2.0 \mathrm{lb} / \mathrm{acre}$ (fig. 20). Unlike suspended-sediment yields, for which only 4 of 26 farm years were greater than the overall mean yield, total-phosphorus yields were distributed relatively evenly above and below the overall mean yield. No farm produced consistently higher or lower total-phosphorus yields than the others: at each farm, total-phosphorus yields were greater than the overall mean yield in at least 1 year.

Total-phosphorus yields were always greater than the overall mean during farm years with the largest annual sediment yields (Pioneer Farm in 2004 and 2008, farm NE1 in 2006 and 2008, and farm NE2 in 2006). These were years in which a majority of the total-phosphorus yields were in runoff during unfrozen-ground periods. There were also several farm years in which total-phosphorus yields were greater than the overall mean but suspended-sediment yields were relatively low (farms SW1 and SW2 in 2005, farm SE1 in 2006, and farm NE2 in 2007, for example). These were years in which most of the total-phosphorus yield was measured in runoff during periods of frozen ground - periods in which sediment yields were lowest.

Overall, a higher proportion of total phosphorus was yielded in runoff during frozen-ground periods than was yielded for sediment. About 40 percent of overall total-phosphorus yields were measured in runoff during frozen-ground periods (fig. 21), compared to 10 percent of suspended-sediment yields measured in runoff during those same periods. These data indicate that total-phosphorus yields were not always associated with suspended sediment and that phosphorus in sediment was not the only important source of phosphorus found in runoff from the farms, especially during frozen-ground periods.

Phosphorus in runoff, other than that attached to soil particles, was likely from a combination of sources including applied manures, fertilizers, soil, plants, and plant residue; however, the coincidence of manure applications and high phosphorus yields and concentrations suggests that phosphorus in manure was a principal source, especially when the manure was applied to fields shortly before a runoff event. Using a subset of four years of runoff and total-phosphorus data for frozen-ground periods at farm SW2, Komiskey and others (2011) determined that the timing of both liquid and solid beef-manure applications in relation to runoff was an important factor in nutrient concentrations and losses measured in runoff during frozen-ground periods. Concentrations and losses of nutrients in runoff were higher from fields where manure was applied to frozen and snow-covered ground less than 1 week before runoff. Lower concentrations and losses were observed when manures were applied in fall and early winter and a period of months elapsed before runoff.

Studies have also shown that the timing of manure and mineral-fertilizer applications relative to runoff events is important to the magnitude of observed phosphorus losses for unfrozen-ground periods as well (Westerman and Overcash, 1980; Sharpley, 1997). An example of this is at farm SE1 in 2008, when manure was applied in early April. Runoff events in late April and in June contributed a majority of the phosphorus yield for the year. The resulting total-phosphorus yield was $6.2 \mathrm{lb} / \mathrm{acre}$, one of the highest for any farm year. Because sediment yields were relatively low for that farm and year (about $260 \mathrm{lb} / \mathrm{acre}$ ), it is likely that the high phosphorus yield was largely due to manure in runoff.

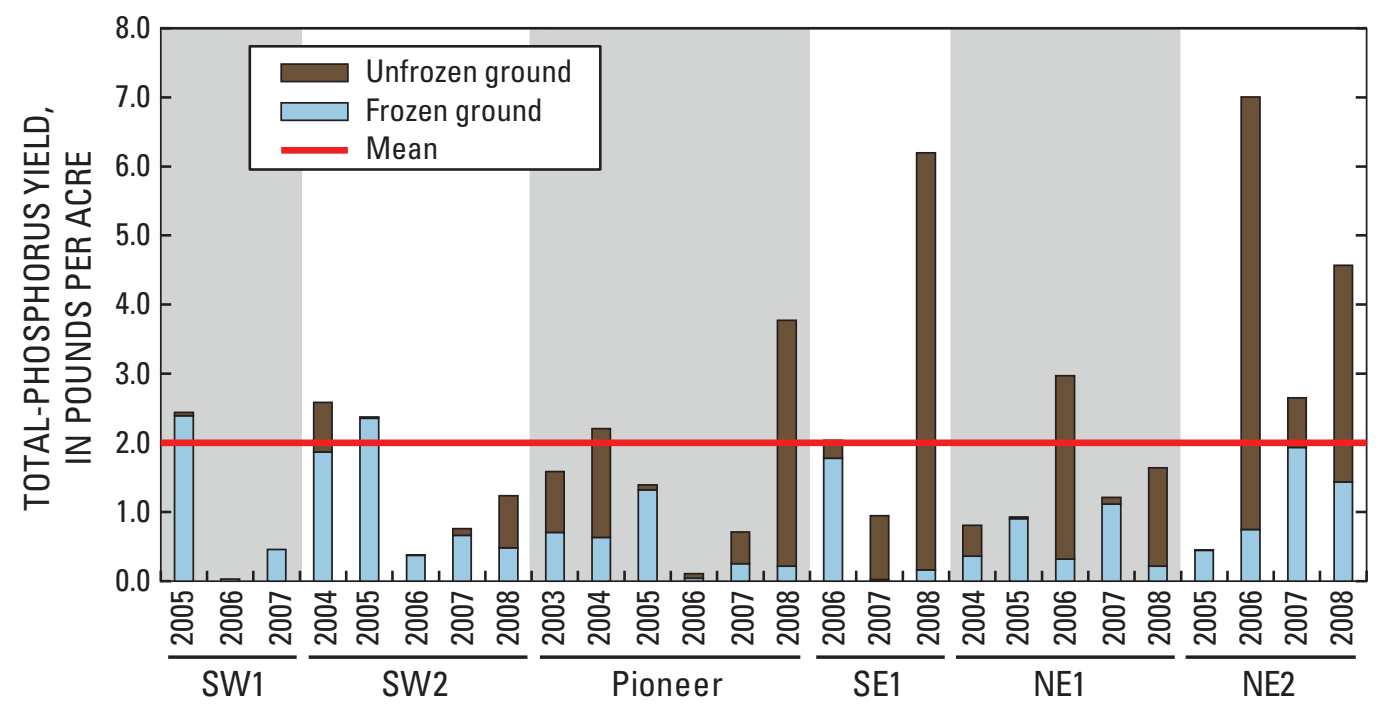

Figure 20. Mean annual total-phosphorus yield, Discovery Farms and Pioneer Farm, water years 2003-8. 


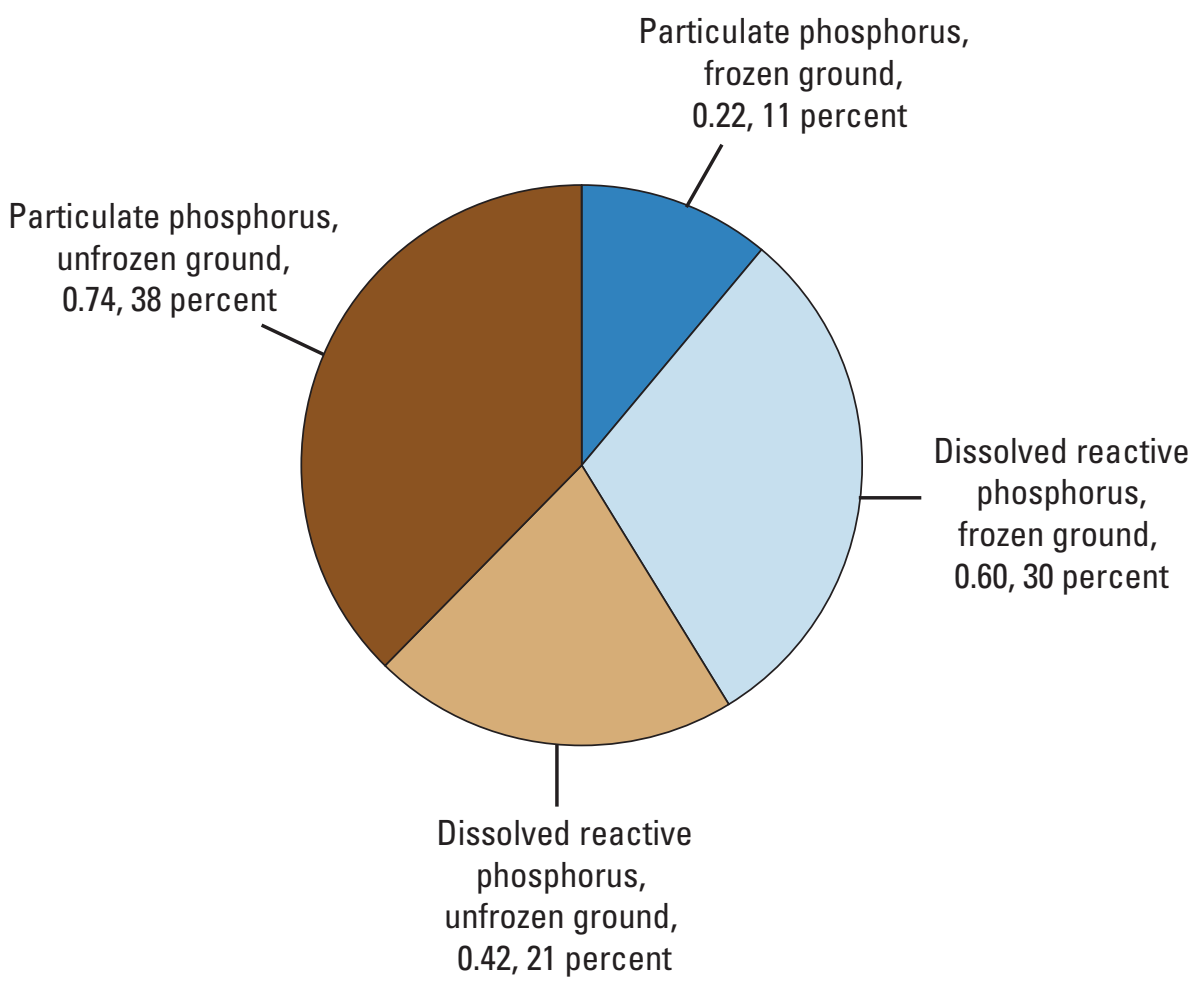

Figure 21. Mean annual phosphorus yield (pounds per acre) and percent of total, by ground condition and phosphorus species, Discovery Farms and Pioneer Farm, water years 2003-8.

\section{Phosphorus Speciation}

Particulate phosphorus has been estimated to be the dominant species of phosphorus transported in runoff from cultivated croplands, unless manure is present and sediment yields are low (Sharpley and others, 1992; Andraski and others, 2003). At the same time, many studies on agricultural runoff indicate that dissolved-phosphorus concentrations in runoff water are directly related to soil-test phosphorus concentrations because of the dissolution of particulate-bound phosphorus from soils into overlying runoff (McDowell and others, 2001; McDowell and Sharpley, 2002; Vadas, Haggard, and Gburek, 2005; Vadas, Kleinman, and others, 2005). Dissolved phosphorus can also be associated with fertilizer and manure applications and derived from plants and plant residues. Understanding the typical distributions between phosphorus species in runoff from Wisconsin fields could help to determine what the specific sources are and how best to minimize losses of phosphorus to water bodies.

\section{Phosphorus Speciation-Concentrations}

Higher concentrations of dissolved and particulate phosphorus in runoff were largely dependent on the ground conditions in which runoff occurred. Event mean concentrations of dissolved phosphorus in runoff during frozen-ground periods were significantly higher $(p<0.05)$ than those during unfrozenground periods, with median concentrations ranging from 0.32 to $2.43 \mathrm{mg} / \mathrm{L}$ among farms during frozen-ground periods and from 0.11 to $3.13 \mathrm{mg} / \mathrm{L}$ among farms during unfrozen-ground periods. Conversely, event mean concentrations of particulate phosphorus in runoff during unfrozen-ground periods were significantly higher $(\mathrm{p}<0.05)$ than those during frozen-ground periods. Median event mean concentrations of particulate phosphorus in runoff ranged from 0.52 to $3.86 \mathrm{mg} / \mathrm{L}$ among farms during unfrozen-ground periods and from 0.25 to $0.70 \mathrm{mg} / \mathrm{L}$ among farms during frozen-ground periods.

Although event mean concentrations of dissolved and particulate phosphorus in runoff were significantly different between frozen- and unfrozen-ground periods, the ranges in concentrations for individual events were relatively similar. Event mean concentrations of dissolved phosphorus ranged from $<0.01$ to $40.70 \mathrm{mg} / \mathrm{L}$, with most of the highest concentrations (greater than $10 \mathrm{mg} / \mathrm{L}$ ) in runoff during the frozenground period and after manure was recently applied. Event mean concentrations of particulate phosphorus ranged from $<0.01$ to $33.20 \mathrm{mg} / \mathrm{L}$. Most of the highest concentrations were recorded during the unfrozen-ground period when suspendedsediment concentrations also were high.

\section{Phosphorus Speciation-Yields}

Overall, mean annual phosphorus yields were nearly equally distributed between dissolved and particulate forms (fig. 21). Mean annual particulate-phosphorus yields averaged $0.96 \mathrm{lb} /$ acre (49 percent of mean annual average), and dissolved-phosphorus yields averaged $1.02 \mathrm{lb} /$ acre (51 percent). Similar to the concentration data, yields of different phosphorus species were dependent, in part, on the ground conditions at the time of runoff. 
Particulate phosphorus constituted a majority of total phosphorus yielded during unfrozen-ground periods (64 percent, or 0.74 of $1.16 \mathrm{lb} / \mathrm{acre})$. Particulate-phosphorus yields were usually related to suspended-sediment yields, as farm years with the highest suspended-sediment yields usually had the highest particulate-phosphorus yields.

Dissolved phosphorus constituted a majority of total phosphorus yielded during frozen-ground periods ( 73 percent, or 0.60 of $0.82 \mathrm{lb} / \mathrm{acre})$. During farm years in which most of the runoff was during frozen-ground periods, yields of dissolved phosphorus usually were higher than those of particulate phosphorus. Exceptions were farms SE1 and NE2 in 2008, when most of the runoff was during unfrozen-ground periods. One would suspect that most phosphorus yielded would be in the particulate form; however, in each case, particulate phosphorus yielded was much lower than the dissolved fraction. Dissolved phosphorus in recently applied manure (one through a surface application, the other by deposition in heavy-use grazed paddocks) was available to contribute to runoff.
Phosphorus yields were highest in February, March, May, and June - the same months in which runoff amounts were also highest (fig. 22). Mean monthly phosphorus yields were strongly correlated with mean monthly runoff amounts $\left(\mathrm{r}^{2}=0.81\right)$ indicating that, unlike suspended sediment, phosphorus was more readily transported in runoff regardless of the ground conditions when runoff occurred. Although about 50 percent of the total phosphorus was yielded in runoff in the particulate form, yields of dissolved phosphorus were higher than those for particulate phosphorus the majority of months. Of note is that in May, when sediment losses were greatest, phosphorus was almost exclusively in the particulate form. The magnitude of the losses in May contributed greatly to the particulate proportion of the overall annual losses summarized in figure 21 . The availability of phosphorus that was not associated with sediment may indicate importance of the residual effects of manure applications or other sources of phosphorus including that in soil, fertilizer, and plant material.

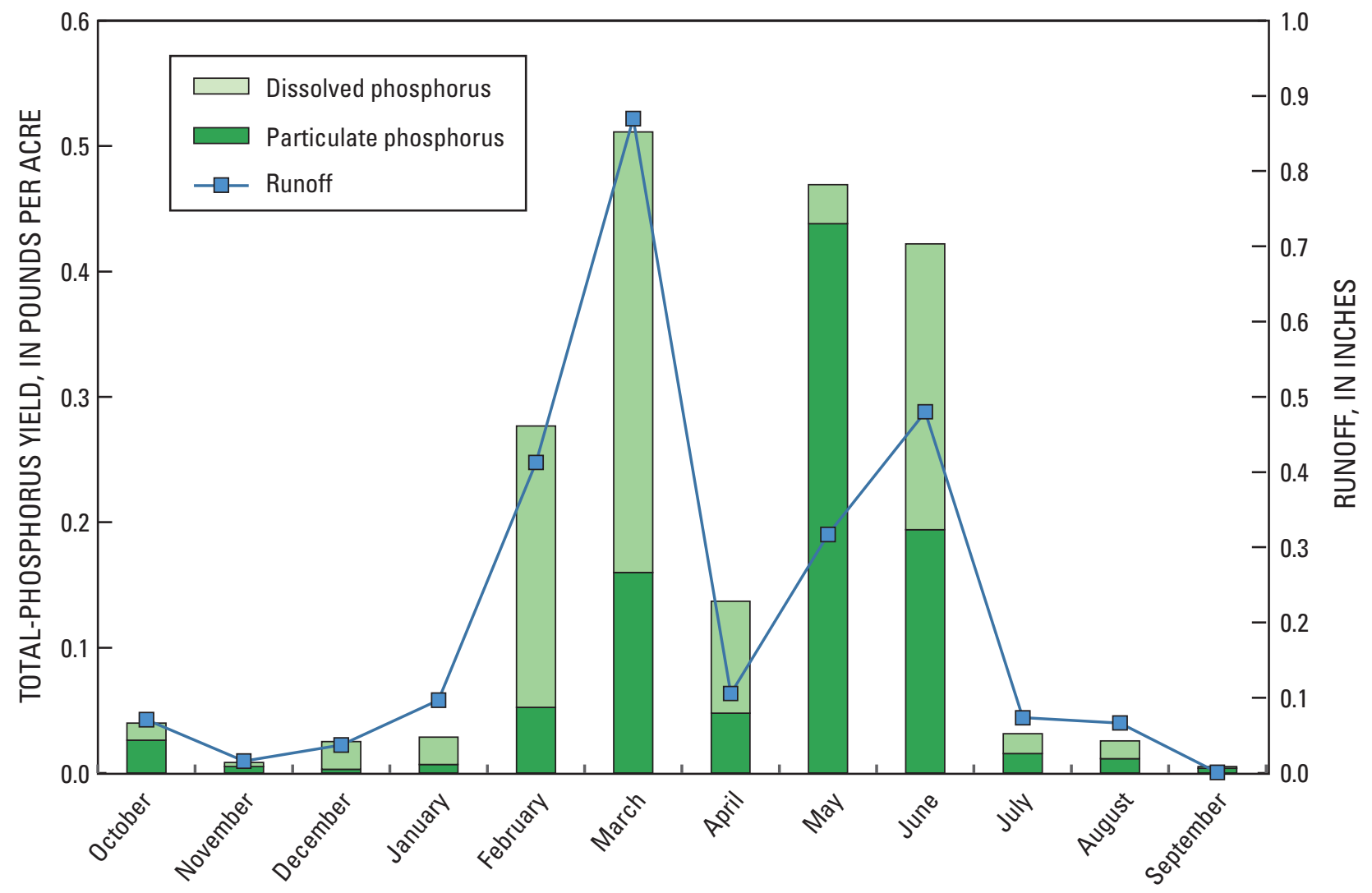

Figure 22. Mean monthly particulate- and dissolved-phosphorus yields and runoff, Discovery Farms and Pioneer Farm, water years 2003-8. 


\section{Nitrogen}

Nitrogen is a valuable nutrient in agricultural systems and essential to production of food, feed, and fiber (Dinnes and others, 2002). Common sources of nitrogen in agricultural landscapes are manure, fertilizers, soil, plants and plant residue, and precipitation. Nitrogen can enter surface-water bodies from a variety of sources; it can be entrained in surface runoff, intercepted and transported in subsurface tile water, or leached to groundwater and then enter streams and lakes through base flow. Nitrogen inputs to water bodies limited by nitrogen are a well-documented concern (Cerco, 1995; Rabalais and others, 2001; Rabalais, 2002). Nitrogen delivered from the U.S. Midwest in the Mississippi River has been identified as a major contributor to the hypoxic zone in the Gulf of Mexico (Rabalais and others, 1996; Burkart and James, 1999). Among the most notable causes of nitrogen contamination of water resources in the Midwest are artificially drained areas, increased use of synthetic fertilizers, and decreased diversity in crop rotation (Dinnes and others, 2002).

Nitrogen is a complex element that exists in numerous forms: organic nitrogen, nitrate plus nitrite (nitrate), and ammonia, among others. Each species has unique characteristics and can become biologically available through complex processes in the nitrogen cycle (Hem, 1985).

Organic nitrogen is nitrogen associated with carboncontaining compounds such as proteins, amino acids, urea, and nitrogen found within living organisms and decaying plant material (Follett, 1995). Some of the organic forms of nitrogen are attached to soil particles and become associated with sediment losses. Other forms of organic nitrogen are found in manure or are associated with plants and plant residue.

Nitrate can be linked to manure, fertilizer, atmospheric, and soil-available nitrogen because it is a stable breakdown product of biological processes. Excess nitrogen, primarily in the form of nitrate, can enter surface-water bodies because it is stable in most natural conditions (Stumm and Morgan, 1981) and is highly soluble (Hook, 1983). Nitrate is a common contaminant leached to groundwater because of its high water solubility and resistance to evaporation (U.S. Environmental Protection Agency, 2006).

Ammonia is a general term for two species of nitrogen that exist in equilibrium in water: un-ionized ammonia $\left(\mathrm{NH}_{3}\right)$ and the ammonium ion $\left(\mathrm{NH}_{4}^{+}\right)$(U.S. Environmental Protection Agency, 1999). Although both forms are potentially toxic to fish and other aquatic organisms, un-ionized ammonia is generally considered to be the more toxic. The proportion of ammonia present and the degree of toxicity depend largely on $\mathrm{pH}$ and, to a lesser degree, temperature. For this study, all ammonia and ammonium were converted to ammonium for laboratory analysis. No attempts were made to distinguish between the forms present in runoff water for this study.

\section{Total-Nitrogen Concentrations}

Event mean concentrations of total nitrogen in runoff during frozen-ground periods were significantly higher $(\mathrm{p}<0.05)$ than those during unfrozen-ground periods. Median event mean concentrations of total nitrogen in runoff ranged from 4.28 to $12.20 \mathrm{mg} / \mathrm{L}$ among farms during frozen-ground periods and from 3.78 to $16.00 \mathrm{mg} / \mathrm{L}$ among farms during unfrozenground periods (fig. 23).

Event mean concentrations of total nitrogen for individual events ranged from 1.30 to $180.05 \mathrm{mg} / \mathrm{L}$ in runoff during frozen-ground periods and from 1.28 to $119.80 \mathrm{mg} / \mathrm{L}$ in runoff during unfrozen-ground periods. The highest concentrations of total nitrogen in runoff were often recorded when manure was applied shortly before runoff (days or weeks) during the frozen-ground period or when sediment concentrations were the highest during the unfrozen-ground period - a finding similar to that for total-phosphorus concentrations.

\section{Total-Nitrogen Yields}

Mean annual total-nitrogen yields ranged from 0.11 to $19.2 \mathrm{lb} / \mathrm{acre}$, with an overall mean of $7.2 \mathrm{lb} / \mathrm{acre}$ (fig. 24). Many farm years with the highest total-nitrogen yields were also those in which mean annual total-phosphorus yields were highest. Farm years with the lowest total-nitrogen yields were often years in which mean annual total-phosphorus yields were lowest. Total-nitrogen yields were nearly equally distributed between periods of frozen ground (52 percent) and unfrozen ground (48 percent), which was similar to the distribution for runoff (54 and 46 percent, respectively). This similarity demonstrates that, like phosphorus, nitrogen was usually available for transport in runoff regardless of ground condition.

\section{Nitrogen Speciation}

Although nitrogen is naturally occurring, additional sources of nitrogen are often found in agricultural systems which, when contributed to surface runoff, may have adverse effects on receiving water bodies. The forms of nitrogen present in runoff and their potential effects can vary greatly depending on nitrogen source, temperature, and other local conditions. Understanding common distributions of nitrogen species in runoff from Wisconsin fields can help to determine specific sources and how best to manage the sources to minimize losses of nitrogen to water bodies. 


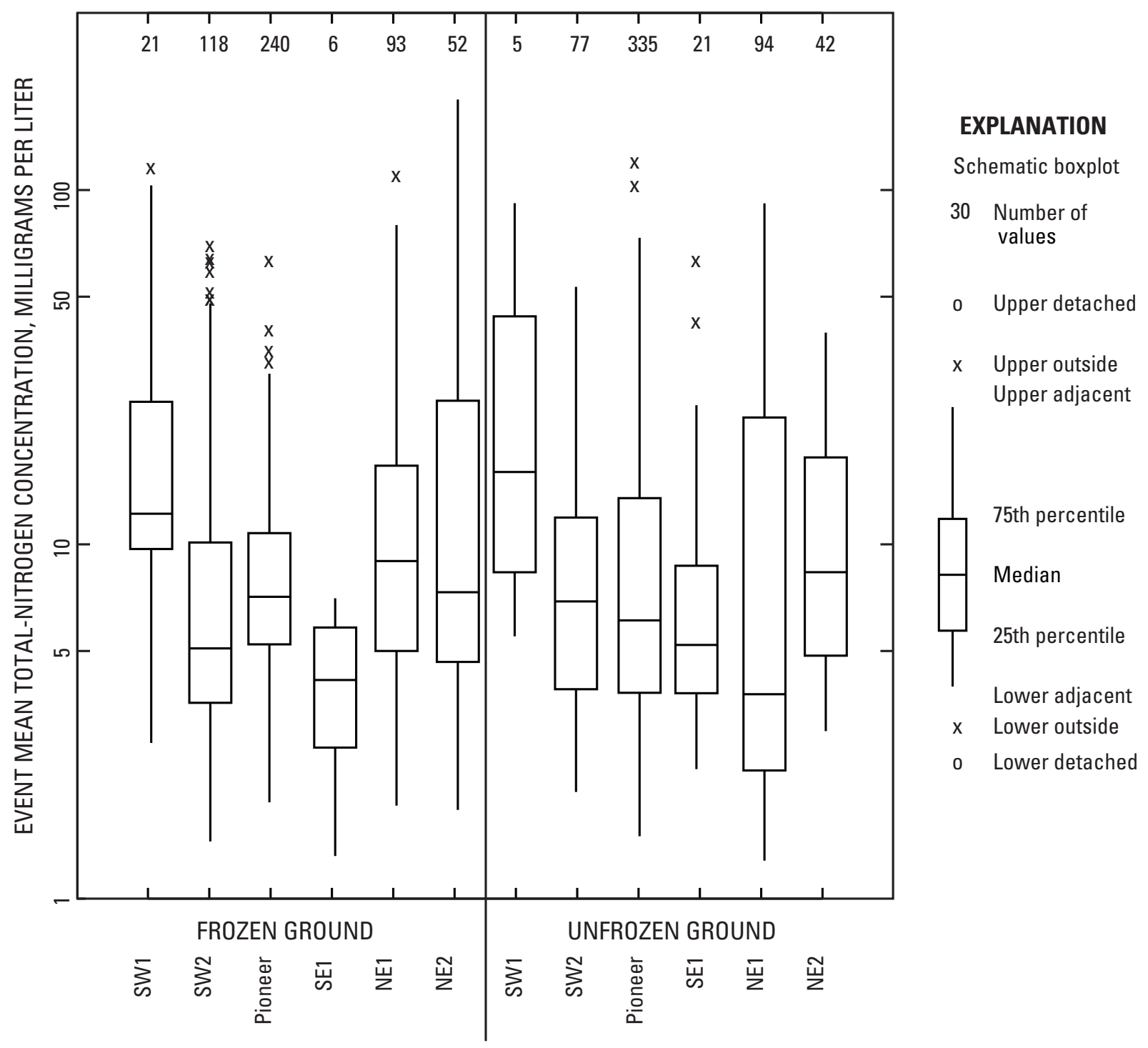

Figure 23. Distribution of event mean concentrations of total nitrogen in runoff during frozen- and unfrozen-ground periods, Discovery Farms and Pioneer Farm, water years 2003-8.

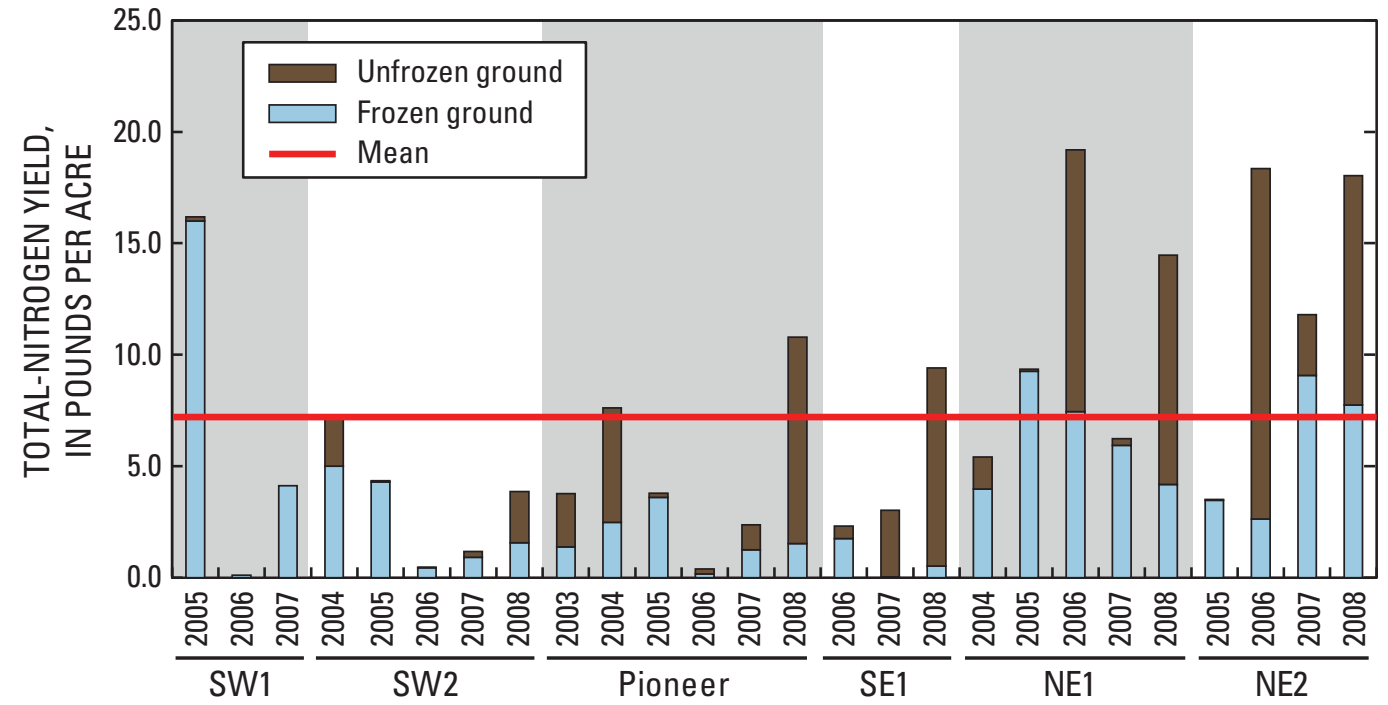

Figure 24. Mean annual total-nitrogen yield, Discovery Farms and Pioneer Farm, water years 2003-8. 


\section{Nitrogen Speciation-Concentrations}

All three forms of nitrogen analyzed for were measured in runoff during the study period, but the resultant forms and concentrations measured depended, in part, on the ground conditions at the time of runoff. Total nitrogen was composed primarily of organic nitrogen for most samples. Event mean concentrations of organic nitrogen were significantly higher $(\mathrm{p}<0.05)$ in runoff during unfrozen-ground periods than during frozen-ground periods. Among the farms, median event mean concentrations of organic nitrogen ranged from 2.52 to $15.35 \mathrm{mg} / \mathrm{L}$ in runoff during unfrozen-ground periods and from 2.00 to $7.50 \mathrm{mg} / \mathrm{L}$ in runoff during frozen-ground periods. Conversely, event mean concentrations of both nitrate and ammonium were significantly higher $(p<0.05)$ in runoff during frozen-ground periods. Median event mean concentrations of nitrate ranged from 0.10 to $1.70 \mathrm{mg} / \mathrm{L}$ in runoff during frozenground periods and from 0.30 to $2.65 \mathrm{mg} / \mathrm{L}$ in runoff during unfrozen-ground periods. Median event mean concentrations of ammonium in runoff ranged from 0.80 to $6.47 \mathrm{mg} / \mathrm{L}$ in runoff during frozen-ground periods and from 0.21 to $0.42 \mathrm{mg} / \mathrm{L}$ in runoff during unfrozen-ground periods.

Event mean concentrations of organic nitrogen, nitrate, and ammonium for individual runoff events ranged from $<0.10$ to $131.50 \mathrm{mg} / \mathrm{L},<0.10$ to $67.00 \mathrm{mg} / \mathrm{L}$, and $<0.10$ to $107.00 \mathrm{mg} / \mathrm{L}$, respectively. Concentrations of organic nitrogen exceeding $40 \mathrm{mg} / \mathrm{L}$ were found in runoff at all farms either in runoff during unfrozen-ground periods when suspendedsediment concentrations were high or in runoff during frozenground periods when manure was recently applied (a few days to a few weeks previously). The highest concentrations of nitrate were observed in runoff during both frozen- and unfrozen-ground periods, almost exclusively at farm NE1. The highest concentrations of ammonium (greater than $10 \mathrm{mg} / \mathrm{L}$ ) were almost always in runoff during frozen-ground conditions and when manure was recently applied. Ammonium concentrations were likely higher in runoff during frozen-ground periods because lower ambient temperatures slowed conversion of ammonium in manure to nitrate and nitrogen gas, thus favoring ammonium in runoff.

\section{Nitrogen Speciation-Yields}

Nitrogen yields were composed primarily of organic nitrogen (3.9 lb/acre, 54 percent of mean annual average), followed by nitrate (1.8 lb/acre, 25 percent) and ammonium (1.5 lb/acre, 21 percent) (fig. 25). As with the concentration data, the resultant forms of nitrogen measured and likely sources depended, in part, on the ground conditions at the time of runoff.
Organic nitrogen was the dominant form of nitrogen yielded in runoff during frozen and unfrozen-ground periods, constituting 45 percent ( 1.7 of $3.8 \mathrm{lb} / \mathrm{acre})$ and 65 percent ( 2.2 of $3.4 \mathrm{lb} /$ acre), respectively, of total nitrogen yielded. Mean annual organic nitrogen yields ranged from 0.07 to $13.9 \mathrm{lb} /$ acre, with an overall annual mean of $3.9 \mathrm{lb} / \mathrm{acre}$. Given the properties of organic nitrogen and that event mean concentrations of organic nitrogen were significantly higher during unfrozen-ground periods, much of the organic nitrogen yielded during unfrozen-ground periods likely was associated with sediment loss. During frozen-ground periods, when sediment loss was typically low, organic nitrogen likely was associated primarily with manure applications.

Nitrate was the second most common form of nitrogen yielded in runoff, constituting 21 percent ( 0.79 of $3.8 \mathrm{lb} /$ acre $)$ of total nitrogen yielded during frozen-ground periods and 29 percent ( 1.0 of $3.4 \mathrm{lb} /$ acre $)$ of total nitrogen yielded during unfrozen-ground periods. Mean annual nitrate yields ranged from 0.02 to $11.2 \mathrm{lb} /$ acre, with an overall annual mean yield of $1.8 \mathrm{lb}$ /acre. Mean annual nitrate yields for most farm years were less than the overall mean yield; however, nitrate yields at farms NE1 and NE2 were consistently higher than the overall mean yield in water years 2006 through 2008. The mean nitrate yield for those farms and years was nearly $6.0 \mathrm{lb} / \mathrm{acre}$.

Although manure additions are likely sources of these higher nitrate yields, confounding data were collected for certain farms and years; specifically, manure was applied and significant runoff occurred, but resultant nitrate yields were low-sometimes less than $0.5 \mathrm{lb} / \mathrm{acre}$. In these cases, nitrate yields were likely lower because the conditions did not favor the conversion of organic nitrogen and ammonium in manure to nitrate. The shorter the time between the manure application and runoff and the less favorable the local conditions (cooler ambient temperatures, for example), the less likely nitrate could be a significant component of nitrogen yielded.

Ammonium was the least common form of nitrogen yielded in runoff, and its presence in runoff was strongly influenced by ground conditions. Although occasionally measured in runoff from unfrozen ground after recent manure applications, ammonium was not a common nitrogen form in runoff during unfrozen-ground periods. Nearly 90 percent of all ammonium was yielded in runoff during frozen-ground periods. The combination of a relatively short time between manure applications and cold temperatures likely slowed the conversion of ammonium to other forms of nitrogen, thus favoring ammonium as an important nitrogen component in runoff during frozen-ground periods. 


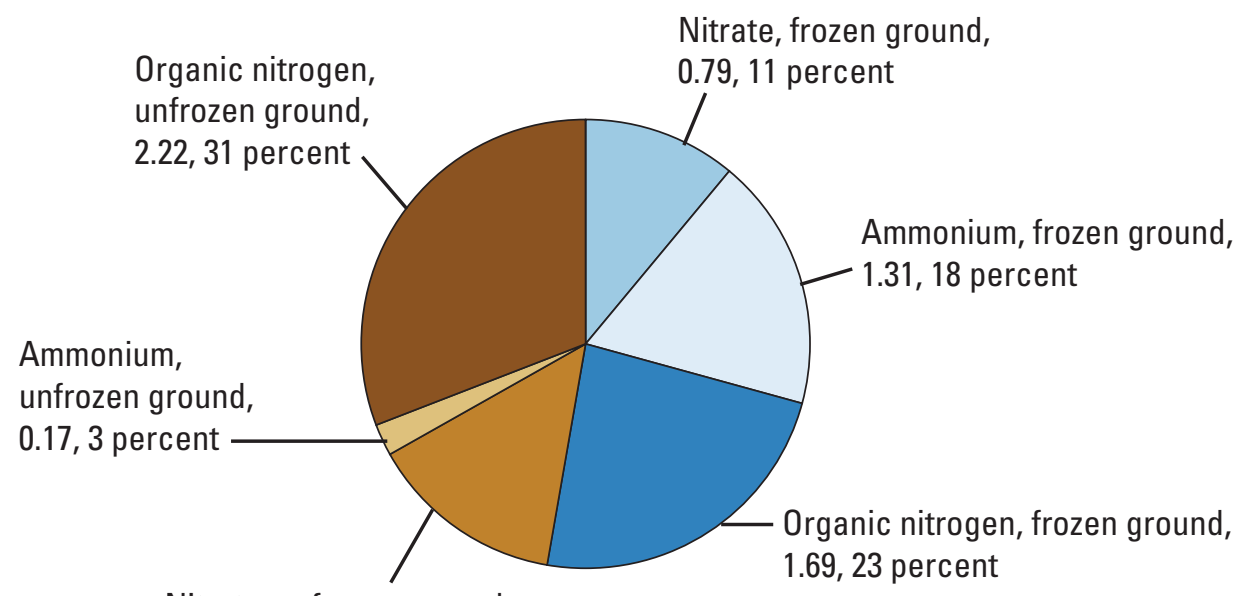

Nitrate, unfrozen ground, 1.01, 14 percent
Figure 25. Mean annual nitrogen yield (pounds per acre) and percent of total, by ground condition and nitrogen species, Discovery Farms and Pioneer Farm, water years 2003-8.
Mean annual ammonium yields ranged from 0.02 to $7.5 \mathrm{lb} /$ acre, with an overall annual mean of $1.5 \mathrm{lb} / \mathrm{acre}$. Ammonium yields for 5 of 26 farm years were above the mean annual yield. In each year, manure was applied shortly before runoff (days to weeks). At farm NE2, two of the three grazed paddocks were overwintered, so this manure was deposited by cows throughout winter.

Nitrogen yields were highest in February, March, May, and June - the same months when runoff amounts and phosphorus yields were also highest (fig. 26). Mean monthly total-nitrogen yields were strongly correlated with mean monthly runoff $\left(\mathrm{r}^{2}=0.93\right)$ and total-phosphorus yields $\left(\mathrm{r}^{2}=\right.$ 0.92 ), indicating that nitrogen was readily transported with runoff and that the sources of nitrogen and phosphorus in runoff were likely similar. Organic nitrogen made up the majority of total nitrogen in most months. Nitrate was the next most dominant form, except for February and March, when ammonium (associated with manure applications) was dominant.

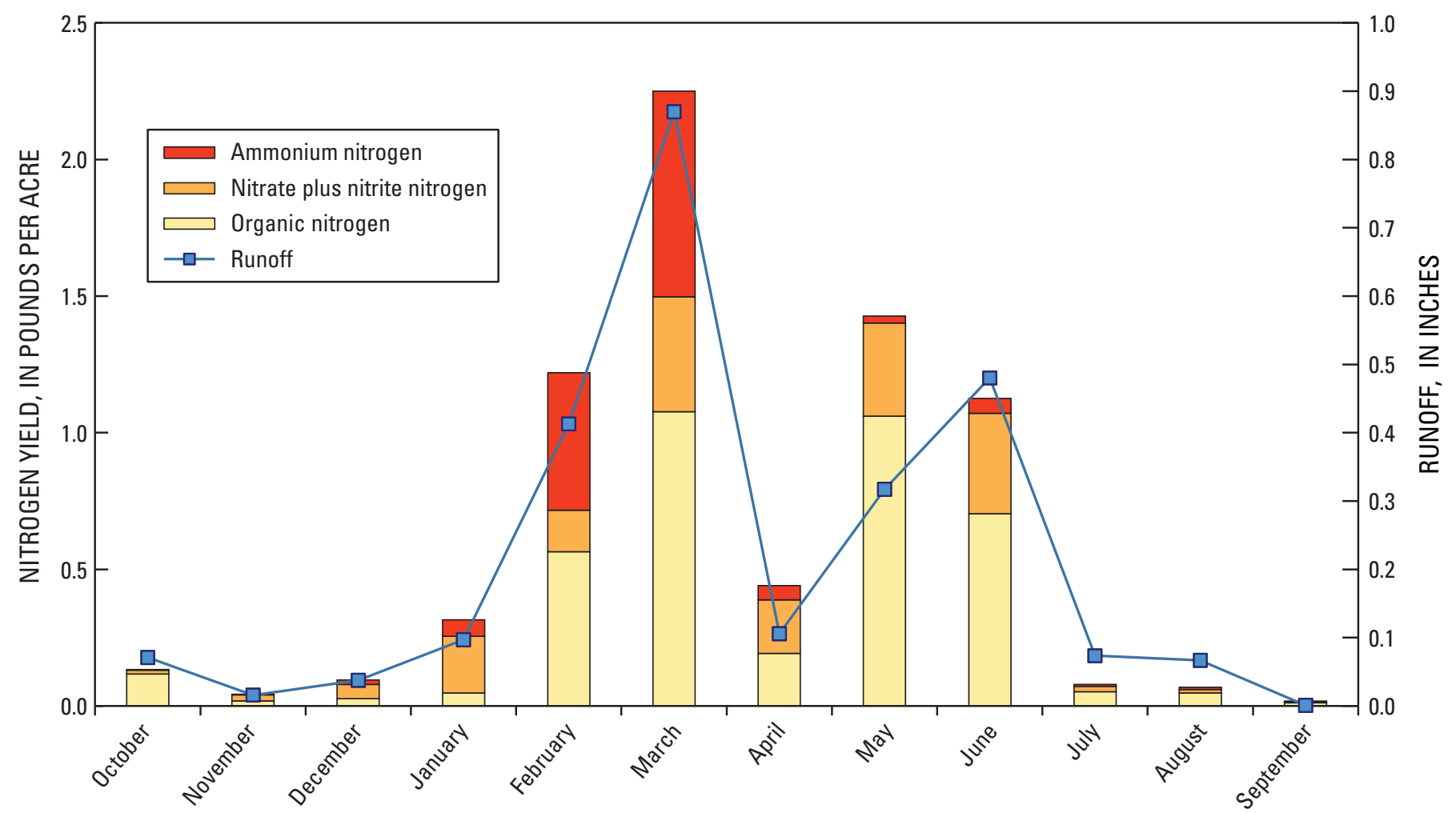

Figure 26. Mean monthly organic nitrogen, nitrate, and ammonium yields and runoff, Discovery Farms and Pioneer Farm, water years 2003-8. 


\section{Summary}

Hydrologic and water-quality data were collected yearround at 23 edge-of-field monitoring stations on 5 privately owned University of Wisconsin (UW)-Madison Discovery Farms and the UW-Platteville Pioneer Farm during water years 2003-8. Data were collected as part of a broad study to identify typical ranges and magnitudes, temporal distributions, and principal factors affecting concentrations and yields of sediment, nutrients, and other selected constituents in runoff from agricultural fields. The studied farms represented landscapes, soils, and farming systems typical of livestock farms throughout southern Wisconsin. The farming systems included two confinement dairies (a medium-sized dairy and a large dairy or concentrated animal feeding operation (CAFO)), a pasture-based dairy, a pasture-based organic dairy, a beef-finishing operation, and a mixed-livestock operation. Each farm employed a variety of soil, nutrient, and water-conservation practices to help minimize sediment and nutrient losses from fields and to improve crop productivity. Data collected at individual monitoring stations were averaged for each farm and for each year to compute average conditions on that farm for that year. The averaged data were termed "farm years." Farm years were chosen (rather than station years) as a primary analysis level to prevent data bias due to unequal distributions of monitoring stations between farms. This report summarizes the precipitation-runoff relations and water-quality characteristics measured in edge-of-field runoff for 26 farm years.

Mean annual precipitation was 32.8 in. for the study period, about 3 percent less than the 30 -year mean. Overall mean annual runoff was 2.55 in. per year (about 8 percent of precipitation) and was nearly equally distributed between periods of frozen ground ( 54 percent) and unfrozen ground (46 percent). For frozen-ground periods, mean monthly runoff was highest in February and March, constituting 50 percent of overall mean annual runoff. Runoff was also observed in March at every farm and during every year of the study period. Most runoff during frozen-ground periods was the result of snowmelt and (or) rain upon snow. For unfrozen-ground periods, mean monthly runoff was highest in May and June, constituting an additional 31 percent of overall mean annual runoff. Antecedent soil moisture was an important factor that affected runoff amounts and the likelihood of runoff during these periods. Ninety percent of annual runoff occurred between January and the end of June.

Suspended-sediment concentrations and yields were affected by the ground conditions at the time of runoff. Event mean concentrations of suspended sediment in runoff during unfrozen-ground periods were significantly higher $(\mathrm{p}<0.05)$ than those during frozen-ground periods. Median event mean concentrations of suspended sediment in runoff ranged from 153 to greater than $3,100 \mathrm{mg} / \mathrm{L}$ among farms during unfrozenground periods and from 24 to $32 \mathrm{mg} / \mathrm{L}$ among farms during frozen-ground periods. Mean annual suspended-sediment yields ranged from 3 to nearly 5,000 lb/acre, with an overall mean yield of $667 \mathrm{lb} /$ acre. Ninety percent of suspended sediment was yielded in runoff during unfrozen-ground periods; May and June alone contributed more than 80 percent of the overall mean. Field-management activities also affected suspended sediment in runoff, as the highest concentrations and yields of suspended sediment were observed in runoff from recently tilled corn fields.

Phosphorus concentrations and yields were affected by the ground conditions at the time of runoff; however, unlike suspended sediment, phosphorus was usually available for transport in runoff regardless of ground condition. Event mean concentrations of total phosphorus in runoff during unfrozen-ground periods were significantly higher $(\mathrm{p}<0.05)$ than those during frozen-ground periods. Median event mean concentrations of total phosphorus in runoff ranged from 0.60 to $2.68 \mathrm{mg} / \mathrm{L}$ among farms during frozen-ground periods and from 1.13 to $4.21 \mathrm{mg} / \mathrm{L}$ during unfrozen-ground periods. Mean annual total-phosphorus yields ranged from 0.03 to $7.0 \mathrm{lb} /$ acre, with an overall mean yield of about $2.0 \mathrm{lb} /$ acre. More phosphorus was yielded in runoff during unfrozen-ground periods than frozen-ground periods (about 60 percent versus 40 percent). Phosphorus yields were highest in February, March, May, and June - the same months in which runoff amounts were also highest. Mean annual phosphorus yields were nearly equally distributed between dissolved and particulate forms; however, the dominant form was dependent on the ground conditions at the time of runoff. Particulate phosphorus was more prevalent in runoff during unfrozen-ground periods, and dissolved phosphorus was more prevalent in runoff during frozen-ground periods. Field-management activities also affected phosphorus in runoff. The highest concentrations of phosphorus in runoff often occurred when manure was applied shortly before runoff (days or weeks) during frozen-ground periods and when sediment yields and concentrations were the highest during unfrozen-ground periods.

Nitrogen in runoff followed similar runoff patterns to phosphorus in that yields were highest during months of highest runoff, and speciation was affected by the ground conditions at the time of runoff. Event mean concentrations of total nitrogen in runoff during frozen-ground periods were significantly higher $(\mathrm{p}<0.05)$ than those during unfrozen-ground periods. Among the farms, median event mean concentrations of total nitrogen in runoff ranged from 4.28 to $12.20 \mathrm{mg} / \mathrm{L}$ among farms during frozen-ground periods and from 3.78 to $16.00 \mathrm{mg} / \mathrm{L}$ among farms during unfrozen-ground periods. Mean annual total-nitrogen yields ranged from 0.11 to 19.2 $\mathrm{lb} /$ acre, and the overall mean was $7.2 \mathrm{lb} / \mathrm{acre}$. Total-nitrogen yields were nearly equally distributed between periods of frozen ground (52 percent) and unfrozen ground (48 percent), and yields were highest in February, March, May, and June. Mean monthly total-nitrogen yields were strongly correlated with mean monthly total-phosphorus yields $\left(r^{2}=0.92\right)$, indicating that the sources of nitrogen and phosphorus in runoff were likely similar. Nitrogen yields were composed primarily of organic nitrogen $(3.9 \mathrm{lb} / \mathrm{acre}, 54$ percent $)$ followed by 
nitrate (1.8 lb/acre, 25 percent) and ammonium $(1.5 \mathrm{lb} / \mathrm{acre}$, 21 percent). The distributions of organic nitrogen and nitrate yields were similar between frozen- and unfrozen-ground periods, but ammonium was more prevalent in runoff during frozen-ground periods than unfrozen-ground periods. Like phosphorus, the highest concentrations of total nitrogen in runoff were often recorded when manure was applied shortly before runoff (days or weeks) during the frozen-ground period or when sediment concentrations were the highest during the unfrozen-ground period.

Analysis of runoff, concentration, and yield data on annual, monthly, and seasonal time scales, when combined with information on precipitation, soil moisture, soil temperature, and on-farm field-activity, revealed conditions in which runoff was most likely and the effects that field conditions and the timing of field-management activities - most notably, manure applications and tillage - had on the quantity and quality of surface runoff from agricultural fields.

\section{Conclusions}

Analysis of the data from this study shows that, in addition to the conservation practices and nutrient-management plans that are in place, awareness of "critical" runoff periods and proper timing of field-management practices in relation to these critical periods and other field conditions may help further reduce sediment, nutrients, and other agrichemicals in edge-of-field runoff.

One of the critical periods when runoff amounts tended to be high was during May and June, when 31 percent of annual runoff was recorded. Runoff during this unfrozen-ground period was typically the result of high-intensity storms or smaller storms during times of high antecedent soil moisture. Many common conservation practices for reducing sediment and nutrient yields in runoff during the unfrozen-ground period rely on living vegetation (grass waterways, buffer strips, and so on) to provide benefits.

Late winter, however, was shown to be an even more critical runoff period. On average, February and March contributed half of the annual runoff total, even though only 11 percent of the annual precipitation fell during those months. Runoff during March was observed at every farm in every year. Typically, the ground was frozen and snow covered during February and March, and most runoff was the result of snowmelt and (or) rain on snow. Because most of the runoff occurred during frozen-ground periods, it is likely that many of the vegetation-based conservation practices may not result in all of the expected benefits. Historically, runoff and water-quality information from frozen-ground periods was not collected, owing to difficulties associated with wintertime hydrologic monitoring in northern climates. Inclusion of this study's data from this critical period provided new insight into farm runoff, and adjustment of agricultural practices to take frozen-ground runoff patterns into account could potentially reduce negative impacts on surface-water quality.

Although these two critical temporal periods accounted for most of the annual runoff on average, actual field conditions affected runoff timing, volumes, and water quality in the short term. In addition to whether the ground was frozen or not, antecedent soil moisture (for unfrozen-ground periods), crop type and crop-canopy stage, and soil type were influential. For example, suspended-sediment concentrations and yields in runoff during frozen-ground periods were typically much lower than those in runoff during unfrozen-ground periods. Therefore, management practices designed to protect against soil erosion during the May-June critical periodbetween spring thaw and establishment of a substantial crop canopy - may have the greatest potential to reduce sediment lost from fields to nearby water bodies.

The timing of field-management activities in relation to the timing of runoff was a final factor that strongly influenced sediment and nutrient concentrations and yields in runoff from field edges. In particular, the application of livestock manure to fields just a few days or weeks before a runoff event usually resulted in elevated nutrient concentrations and yields. Timing of tillage before a runoff event was also found to be a factor that affected sediment and nutrient concentrations. The influences of other field-management activities were not as evident as the influences of manure applications or tillage; however, it is likely that other such activities (for example, chemical fertilizer or pesticide applications) in advance of runoff would have some effect on water quality as well.

Each studied farm employed a variety of soil, nutrient, and water-conservation practices to help minimize sediment and nutrient losses from fields and to improve crop productivity. Integration of the lessons learned from this study with established conservation practices may be more effective at reducing sediment and nutrient losses to surface waters than the practices alone. In summary, field activities managed with consideration of critical runoff periods and field conditions may further protect water quality. 


\section{References Cited}

Andraski, T.W., Bundy, L.G., and Kilian, K.C., 2003, Manure history and long-term tillage effects on soil properties and phosphorus losses in runoff: Journal of Environmental Quality, v. 32, no. 5, p. 1782-1789.

Baxter, M.A., Graves, C.E., and Moore, J.T., 2005, A climatology of snow-to-liquid ratio for the contiguous United States: Weather and Forecasting, v. 20, no. 5, p. 729-744.

Bayard, Daniel; Stähli, Manfred; Parriaux, Aurèle; and Flühler, Hannes; 2004, The influence of seasonally frozen soil on the snowmelt runoff at two Alpine sites in southern Switzerland: Journal of Hydrology, v. 309, nos. 1-4, p. 66-84.

Burkart, M.R., and James, D.E., 1999, Agricultural-nitrogen contributions to hypoxia in the Gulf of Mexico: Journal of Environmental Quality, v. 28, no. 3, p. 850-859.

Cerco, C.F., 1995, Simulation of long-term trends in Chesapeake Bay eutrophication: Journal of Environmental Engineering, v. 121, no. 4, p. 298-310.

Daniel, T.C., Sharpley, A.N., and Lemunyon, J.L., 1998, Agricultural phosphorus and eutrophication-A symposium overview: Journal of Environmental Quality, v. 27, no. 2, p. $251-257$.

Daniel, J.A., and Staricka, J.A., 2000, Frozen soil impact on ground water-surface water interaction: Journal of the American Water Resources Association, v. 36, no. 1, p. 151-160.

Dinnes, D.L, Karlen, D.L., Jaynes, D.B., Kaspar, T.C., Hatfield, J.L., Colvin, T.S., and Cambardella, C.A., 2002, Nitrogen management strategies to reduce nitrate leaching in tile-drained Midwestern soils: Agronomy Journal, v. 94, no. 1, p. $153-171$.

Dunne, T., and Leopold, L.B., 1978, Water in environmental planning: New York, W.H. Freeman, 818 p.

Erb, K., and Stieglitz, R., 2007, Final report of the Northeast Wisconsin Karst Task Force, accessed May 12, 2009, at http://learningstore.uwex.edu/Assets/pdfs/G3836.pdf.

Fitzpatrick, F.A., Knox, J.C., and Schubauer-Berigan, J.P., 2007, Sedimentation history of Halfway Creek Marsh, Upper Mississippi Wildlife and Fish Refuge, Wisconsin, 1846-2006: U.S. Geological Survey Scientific Investigations Report 2007-5209, 40 p.

Follett, R.F., 1995, Fate and transport of nutrients-Nitrogen: Natural Resources Conservation Service Soil and Water Resources Conservation Act publication archive, Working Paper No. 7, accessed May 12, 2010, at http://www.nrcs. usda.gov/technical/rca/wp07text.html.
Garn, H.S., 2002, Surface-water quality-assurance plan for the Wisconsin District of the U.S. Geological Survey, Water Resources Division: U.S. Geological Survey Open-File Report 02-30, $52 \mathrm{p}$.

Griffith, G.E., and Omernik, J.A. (lead authors); and McGinley, Mark (topic editor), 2009, Ecoregions of Wisconsin (EPA), in Encyclopedia of Earth, accessed May 12, 2010, at http://www.eoearth.org/article/Ecoregions_of_Wisconsin_(EPA).

Haggard, B.E., Smith, D.R, and Brye, K.R., 2007, Variations in stream water and sediment phosphorus among select Ozark catchments: Journal of Environmental Quality, v. 36, no. 6 , p. 1725-1734.

Helsel, D.R. 2005, Nondetects and data analysis - Statistics for censored environmental data: Hoboken, N.J., WileyInterscience, $250 \mathrm{p}$.

Hem, J.D, 1985, Study and interpretation of the chemical characteristics of natural water ( $3 \mathrm{~d}$ ed.): U. S. Geological Survey Water-Supply Paper 2254, 263 p., 3 pls.

Hole, F.D., Beatty, M.T., Milford, C.J., Lee, G.B., and Klingelhoets, A.J., 1968, Soils of Wisconsin: University of Wisconsin-Extension, scale 1:710,000, 1 sheet.

Hook, J.E., 1983, Movement of phosphorus and nitrogen in soil following application of municipal wastewater, in Chemical Mobility and Reactivity in Soil Systems, Soil Science Society of America and American Society of Agronomy symposium, Atlanta, Ga., November 29-December 3, 1981, proceedings: Madison, Wis., Soil Science Society of America Special Publication No. 11, p. 241-255.

Huff, F.A., and Angel, J.R., 1992, Rainfall frequency atlas of the Midwest: Illinois State Water Survey Bulletin 71, 141 p.

Juckem, P.F., Hunt, R.J., Anderson, M.P., and Robertson, D.M., 2008, Effects of climate and land management change on streamflow in the driftless area of Wisconsin: Journal of Hydrology, v. 355, nos. 1-4, p. 123-130.

Kane, D.L., and Chacho, E.F., Jr., 1990, Frozen ground effects on infiltration and runoff: New York, American Society of Civil Engineers, Committee Report Paper for Cold Regions Hydrology and Hydraulics, p. 259-300.

Komiskey, M.J., Stuntebeck, T.D., Frame, D.R., and Madison, F.W., 2011, Nutrients and sediment in frozen-ground runoff from no-till fields receiving liquid-dairy and solid-beef manures: Journal of Soil and Water Conservation, v. 66.

Koss, W.J., Owenby, J.R., Steurer, P.M., and Ezell, D.S., 1988, Freeze/frost data: Asheville, N.C., National Oceanic and Atmospheric Administration, National Climatic Data Center, Climatography of the U.S. No. 20, Supplement No. 1 [variously paginated]. 
Martin, Lawrence, 1965, The physical geography of Wiscon$\sin (3 \mathrm{~d}$ ed.): Madison, Wis., University of Wisconsin Press, $608 \mathrm{p}$.

McDowell, Richard, and Sharpley, Andrew, 2002, Phosphorus transport in overland flow in response to position of manure application: Journal of Environmental Quality, v. 31, no. 1, p. 217-227.

McDowell, Richard; Sharpley, Andrew; and Folmar, Gordon, 2001, Phosphorus export from an agricultural watershedLinking source and transport mechanisms: Journal of Environmental Quality, v. 30, no. 5, p. 1587-1595.

Moran, J.M., and Hopkins, E.J., 2002, Wisconsin's weather and climate: Madison, Wis., University of Wisconsin Press, $321 \mathrm{p}$.

National Environmental Methods Index, 2009, Online data available at www.nemi.gov.

National Oceanic and Atmospheric Administration, National Environmental Satellite, Data, and Information Service (NESDIS), 2009, data available online at http://www.ncdc. noaa.gov/oa/ncdc.html

Owens, L.B., and Shipitalo, M.J., 2006, Surface and subsurface phosphorus losses from fertilized pasture systems in Ohio: Journal of Environmental Quality, v. 35, no. 4, p. 1101-1109.

Ott, R.L., and Longnecker, Michael, 2001, An introduction to statistical methods and data analysis (5th ed.): Pacific Grove, Calif., Wadsworth Group, 1,152 p.

Peters, C.A., ed., 1997, Environmental setting and implications for water quality in the Western Lake Michigan drainages: U.S. Geological Survey Water-Resources Investigations Report 97-4196, 79 p.

Porterfield, George, 1972, Computation of fluvial-sediment discharge: U.S. Geological Survey Techniques of WaterResources Investigations, book 3, chap. C3, 66 p.

Rabalais, N.N., 2002, Nitrogen in aquatic ecosystems: Ambio, v. 31, no. 2, p. 102-112.

Rabalais, N.N.; Turner, R.E.; Justić, Dubravko; Dortch, Quay; Wiseman, W.J., Jr.; and Sen Gupta, B.K., 1996, Nutrient changes in the Mississippi River and system responses on the adjacent continental shelf: Estuaries and Coasts, v. 19, no. 2B, p. 386-407.

Rabalais, N.N., Turner, R.E., and Wiseman, W.J., Jr., 2001, Hypoxia in the Gulf of Mexico: Journal of Environmental Quality, v. 30, no. 2, p. 320-329.
Radatz, T.F., 2009, Soil moisture and rainfall-runoff response of agricultural basins in southwestern Wisconsin during non-frozen-ground periods: University of Wisconsin-Madison, M.S. thesis, $118 \mathrm{p}$.

Reese, H.M., Lillesand, T.M., Nagel, D.E., Stewart, J.S., Goldmann, R.A., Simmons, T.E., Chipman, J.W., and Tessar, P.A., 2002, Statewide land cover derived from multiseasonal Landsat TM data-A retrospective of the WISCLAND project: Remote Sensing of Environment, v. 82, no. 2-3, p. 224-237.

Richards, K.D., Elder, J.F., and Corsi, S.R., 2006, Qualityassurance plan for water-quality activities in the Wisconsin Water Science Center: Unpublished document on file at the U.S. Geological Survey Wisconsin Water Science Center, Middleton, Wis.

Robertson, D.M., Saad, D.A., and Heisey, D.M., 2006, Present and reference concentrations and yields of suspended sediment in streams in the Great Lakes Region and adjacent areas: U.S. Geological Survey Scientific Investigations Report 2006-5066, 35 p.

Ruark, M.D., Panuska, J.C., and Cooley, E.T., 2009, Tile drainage in Wisconsin-Understanding and locating tile drainage systems: University of Wisconsin-Extension, Discovery Farms, Fact Sheet No. 1, 4 p., accessed May 12, 2010, at http://www.uwdiscoveryfarms.org/pdf/pubsnewsres/ DF-TD1.pdf.

Schmidt, R.R., 1987, Groundwater contamination susceptibility map and evaluation: Wisconsin Department of Natural Resources, Wisconsin's Groundwater Management Plan Report 5, PUBL-WR-177-87, 27 p.

Selbig, W.R., Jopke, P.L., Marshall, D.W., and Sorge, M.J., 2004, Hydrologic, ecologic, and geomorphic responses of Brewery Creek to construction of a residential subdivision, Dane County, Wisconsin, 1999-2002: U.S. Geological Survey Scientific Investigations Report 2004-5156, 33 p.

Sharpley, A.N., 1997, Rainfall frequency and nitrogen and phosphorus in runoff from soil amended with poultry litter: Journal of Environmental Quality, v. 26, no. 4, p. $1127-$ 1132 .

Sharpley, A.N., Smith, S.J., Jones, O.R., Berg, W.A., and Coleman, G.A., 1992, The transport of bioavailable phosphorus in agricultural runoff: Journal of Environmental Quality, v. 21 , no. 1, p. $30-35$.

Sharpley, A.N., Daniel, T.C, Sims, J.T., Lemunyon, J., and Parry, R., 1999, Agricultural phosphorus and eutrophication: U.S. Department of Agriculture, Agricultural Resource Service publication ARS-149, $37 \mathrm{p}$. 
Srinivasan, M.S., Bryant, R.B., Callahan, M.P., and Weld, J.L., 2006, Manure management and nutrient loss under winter conditions - A literature review: Journal of Soil and Water Conservation, v. 61, no. 4, p. 200-209.

Stumm, Werner, and Morgan, J.J., 1981, Aquatic chemistry ( $2 \mathrm{~d}$ ed.): New York, Wiley-Interscience, $780 \mathrm{p}$.

Stuntebeck, T.D., Komiskey, M.J., Owens, D.W., and Hall, D.W., 2008, Methods of data collection, sample processing, and data analysis for edge-of-field, streamgaging, subsurface-tile, and meteorological stations at Discovery Farms and Pioneer Farm in Wisconsin, 2001-7: U.S. Geological Survey Open-File Report 2008-1015, 51 p.

Sturgul, S.J., and Bundy, L.G., 2002, Understanding soil phosphorus: University of Wisconsin Cooperative Extension Service Bulletin A3731, 32 p.

Sylvan, J.B.; Dortch, Quay; Nelson, D.M.; Maier Brown, A.F.; Morrison, Wendy; and Ammerman, J.W., 2006, Phosphorus limits phytoplankton growth on the Louisiana shelf during the period of hypoxia formation: Environmental Science \& Technology, v. 40, no. 24, p. 7548-7553.

U.S. Department of Agriculture, Natural Resources Conservation Service, 2009, Web soil survey data, accessed May 12, 2010, at http://websoilsurvey.nrcs.usda.gov/app/WebSoilSurvey.aspx.

U.S. Department of Agriculture, 2008, National Agriculture Imagery Program (NAIP) information sheet, accessed May 12, 2010, at $h t t p: / / w w w . f s a . u s d a . g o v / I n t e r n e t / F S A$ File/naip_2007_infosheetpdf.pdf.

U.S. Environmental Protection Agency, 2007, Level III Ecoregions of the Continental United States: Online map accessed May 12, 2010, at http://www.epa.gov/wed/pages/ ecoregions/level_iii.htm.

U.S. Environmental Protection Agency, 1998, National strategy for the development of regional nutrient criteria: U.S. Environmental Protection Agency, Office of Water, EPA-822-R-98-002, 47 p.

U.S. Environmental Protection Agency, 1999, 1999 Update of ambient water quality criteria for ammonia: Office of Water, EPA-822-R-99-014, 147 p., accessed June 30, 2009, at http://www.epa.gov/waterscience/criteria/ ammonia/99update.pdf.

U.S. Environmental Protection Agency, 2006, Basic information about nitrate/nitrite in drinking water, accessed June 30, 2009, at http://www.epa.gov/ogwdw000/contaminants/ $d w \_$contamfs/nitrates.html.
U.S. Geological Survey, 2005-9, Water resources data for the United States, water years 2004 through 2008-Wisconsin data: Available at http://wdr.water.usgs.gov/.

Vadas, P.A., Haggard, B.E., and Gburek, W.J., 2005, Predicting dissolved phosphorus in runoff from manured field plots: Journal of Environmental Quality, v. 34, no. 4, p. 1347-1353.

Vadas, P.A., Kleinman, P.J.A., Sharpley, A.N., and Turner, B.L., 2005, Relating soil phosphorus to dissolved phosphorus in runoff-A single extraction coefficient for water quality modeling: Journal of Environmental Quality, v. 34, no. 2 , p. $572-580$.

Walker, J.F., and Krug, W.R., 2003, Flood-frequency characteristics of Wisconsin streams: U.S. Geological Survey Water-Resources Investigations Report 03-4250, 37 p.

Waters, T.F., 1995, Sediment in streams-Sources, biological effects, and control: Bethesda, Md., American Fisheries Society Monograph 7, $251 \mathrm{p}$.

Westerman, P.W., and Overcash, M.R., 1980, Short-term attenuation of runoff pollution potential for land-applied swine and poultry manure, in Livestock waste-A renewable resource, Proceedings of the Fourth International Symposium on Livestock Wastes, Amarillo, Tex., April 15-18, 1980: St. Joseph, Mich., American Society of Agricultural Engineers, p. 289-292.

Wisconsin Department of Natural Resources, 1998, WISCLAND Land Cover (WLCGW930): WDNR, Digital data available at $h t t p: / / d n r$ wi.gov/maps/gis/datalandcover. html\#app.

Wisconsin Legislative Fiscal Bureau, 2001, Agricultural Stewardship Initiative (UW System): Wisconsin Joint Committee on Finance Paper 955, LFB 2001-03, Budget Summary, Page $687 \# 15$, accessed June 26, 2009, at http://www.legis. state.wi.us/lfb/2001-03budget/2001-03budgetpapers/955. $p d f$.

Wisconsin State Climatology Office, 2009a, Wisconsin climate by division: Downloadable data available at $h t t p: / / w w w . a o s$. wisc.edu/ sco/clim-history/division/index.html.

Wisconsin State Climatology Office, 2009b, Climate of Wisconsin: Adapted from U.S. Weather Bureau, 1959, Climatography of the United States No. 60, accessed June 29, 2009, at http://www.uwex.edu/sco/stateclimate.html.

Zuzel, J.F., and Pikul, J.L, Jr., 1987, Infiltration into a seasonally frozen agricultural soil: Journal of Soil and Water Conservation, v. 42 , no. 6 , p. $447-450$. 


\section{Appendixes: Instructions for Downloading}

The appendixes for this report are published separately in electronic form. They can be downloaded from the USGS Publications Warehouse at the following URL:

http:// pubs.usgs.gov/sir/2011/5008/.

Appendix 1. Monthly and annual rainfall, snowfall, snowfall liquid equivalent, total precipitation, and runoff, Discovery

Farms and Pioneer Farm, various water years

Appendix 2. Selected summary statistics, in milligrams per liter, for event mean constituent concentrations measured in annual runoff and during frozen- and unfrozen-ground periods, Discovery Farms and Pioneer Farm, water years 2003-8
Appendix 3. Annual surface-water runoff and constituent yields divided into frozen- and unfrozen-ground periods, Discovery Farms and Pioneer Farm, water years 2003-8

Appendix 4. Minimum, maximum, and mean annual runoff and constituent yields and distributions for frozen- and unfrozen-ground periods, Discovery Farms and Pioneer Farm, water years 2003-8

Appendix 5. Mean monthly runoff, precipitation, and constituent yields, Discovery Farms and Pioneer Farm, water years 2003-8 
Publishing support provided by the U.S. Geological Survey Science Publishing Network, Columbus Publishing Service Center For more information concerning the research in this report, contact the Director, Wisconsin Water Science Center

U.S. Geological Survey

8505 Research Way

Middleton, Wisconsin 53562

http://wi.water.usgs.gov/ 
